\title{
Unlocking infrastructure investment
}

Innovative funding and financing in regions and cities

OECD Report for the G20 Infrastructure Working Group 


\title{
Unlocking infrastructure investment: Innovative funding and financing in regions and cities
}

\section{OECD Report for the G20 Infrastructure Working Group}

\begin{abstract}
This report provides an overview of funding and financing instruments available to support infrastructure investment in cities and regions. Subnational governments have a critical role to deliver, operate and maintain infrastructure, and to invest to help drive the recovery from COVID-19. In recent years, many subnational governments have introduced innovations in the types of instruments used to access funding and financing. Highlighting examples from G20, OECD and non-OECD countries, this report presents a framework to differentiate funding and financing instruments, including by type of instrument, and their use, and outlines essential framework conditions that are needed to support subnational governments. The paper was submitted to the G20 Infrastructure Working Group under the Italian Presidency and key findings were presented at the G20 High-level Conference on Local Infrastructure in Genoa, Italy on 27 September 2021.
\end{abstract}

JEL codes: H54, O18, R42, R51

Keywords: Infrastructure, Subnational Governments, Public Investment, G20, COVID-19, Funding, Financing, Cities, Regions, Bonds, Loans, Taxes, User charges, Public Private Partnerships, State Owned Enterprises.

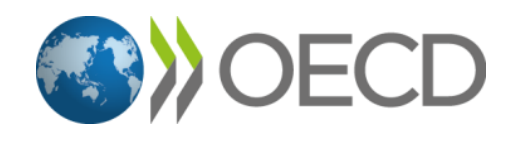


The OECD is a multi-disciplinary inter-governmental organisation of 38 member countries which engages in its work an increasing number of non-members from all regions of the world. The Organisation's core mission today is to help governments work together towards a stronger, cleaner, fairer global economy. Through its network of 250 specialised committees and working groups, the OECD provides a setting where governments compare policy experiences, seek answers to common problems, identify good practice, and co-ordinate domestic and international policies. More information available: www.oecd.org.

This report was authorised for publication by Lamia Kamal-Chaoui, Director, Centre for Entrepreneurship, SMEs, Regions and Cities, OECD.

This document, as well as any statistical data and map included herein, are without prejudice to the status of or sovereignty over any territory, to the delimitation of international frontiers and boundaries and to the name of any territory, city or area.

The statistical data for Israel are supplied by and under the responsibility of the relevant Israeli authorities. The use of such data by the OECD is without prejudice to the status of the Golan Heights, East Jerusalem and Israeli settlements in the West Bank under the terms of international law.

\section{(C) OECD 2021}

You can copy, download or print OECD content for your own use, and you can include excerpts from OECD publications, databases and multimedia products in your own documents, presentations, blogs, websites and teaching materials, provided that suitable acknowledgement of OECD as source and copyright owner is given. All requests for public or commercial use and translation rights should be submitted to rights@oecd.org. 


\section{Foreword}

With countries beginning to recover from the immediate impacts of the COVID-19 crisis, attention is now focussed on securing an inclusive, sustainable and resilient recovery. High quality infrastructure investment will be a critical component of the recovery given its material impact on people's day-to-day lives and its centrality in supporting the green and digital transitions. With responsibility for $60 \%$ of public investment, subnational governments (state, regional and local) in G20 countries have an essential role to play. However, to support infrastructure investment, it is essential that they have the right tools and framework conditions.

To assist subnational governments, this paper highlights innovations relating to funding and financing that have been adopted by subnational governments to support infrastructure investment. Drawing on examples from G20, OECD and non-OECD countries, it describes new and innovative instruments, and highlights innovations in the use of well-established instruments, particularly where cities and regions innovate by adapting to their specific contexts. The report highlights six areas of innovation relating to funding and five areas relating to financing. Innovations cover the improved use of existing assets, new forms and applications of taxes and user charges and fees, the use of bonds and new types of funding providers, amongst others. The report also highlights two types of approaches to investment that harness funding and financing to deliver a project: subnational public private partnerships (PPPs) and subnational state-owned enterprises (SOEs).

To unlock subnational government investment and the use of funding and financing instruments, the right framework conditions need to be in place. However, subnational governments often face specific obstacles that can limit their ability to invest. This report focuses on four key framework conditions that need to be in place: (i) ensuring that subnational governments have the fiscal space and financial capacity to invest; (ii) building investment capabilities; (iii) establishing legal and regulatory frameworks; and, (iv) increasing coordination and cooperation among and across levels of government.

Addressing the challenges of the COVID-19 crisis, demographic change, climate change and digitalisation in regions and cities requires supporting subnational government investment. As we continue to recover from the COVID-19 crisis and seek to meet long-term regional development objectives, this report seeks to provide real world examples to national and subnational governments that can help to support quality infrastructure investment in all regions and cities. 


\section{Acknowledgements}

This policy paper was produced by the OECD Centre for Entrepreneurship, SMEs, Regions and Cities (CFE), led by Lamia Kamal-Chaoui, Director, as part of the programme of work 2021-2022 of the Regional Development Policy Committee (RDPC).

The paper was led by Dorothée Allain-Dupré, Head of the Regional Development and Multi-level Governance Division in CFE, and co-ordinated by Isabelle Chatry, Head of the Decentralisation, Subnational Finance and Infrastructure Unit. It was drafted by Courtenay Wheeler and Yingyin Wu, Policy Analysts in CFE. This paper incorporates insights and comments from Nadim Ahmad, Deputy Director of CFE. It also benefitted from inputs by Maria Varinia Michalun, Jose Enrique Garcilazo and Ana Moreno Monroy from CFE; Sean Dougherty, Edwin Lau, Ana Maria Ruiz Rivadeneira and Lorena Cruz Serrano from the Public Governance Directorate; as well as Andre Laboul, Mamiko Yokoi-Arai, Timothy Bishop and Raffaele Della Croce from the Directorate for Financial and Enterprise Affairs (DAF). Special thanks are extended to Andre Taddei (Italian Ministry of Economy and Finance) and Anwar Shah (Senior Fellow (nonresident) at Brookings Institution) who also provided valuable feedback on the paper. Thanks are also extended to Pilar Philip who helped to prepare the final publication and Nikki Trutter for the cover.

This policy paper is part of the OECD horizontal work on infrastructure that has contributed to the Infrastructure Working Group under the Italian G20 Presidency. The horizontal work was supervised by André Laboul, former Head of the OECD Financial Affairs Division, and coordinated by Mamiko YokoiArai, Deputy Head of Financial Markets Division and Head of Infrastructure and Alternative Financing Unit in DAF. Key findings of this policy paper were presented by Dorothée Allain-Dupré at the G20 High-level Conference on Local Infrastructure on 27 September 2021 in Genoa, Italy.

We would like to thank the delegates of the OECD Regional Development Policy Committee, the G20 Infrastructure Working Group, and the G20/OECD Task Force on Institutional Investors and Long-term Financing, who provided comments on a draft of this paper. 


\section{Table of contents}

Foreword 3

Acknowledgements $\quad 4$

$\begin{array}{ll}\text { Executive summary } & 7\end{array}$

1 Introduction 11

2 Subnational infrastructure investment for the COVID-19 recovery and beyond 13

Subnational governments are important infrastructure investors 13

Regions and cities face different infrastructure challenges 14

Supporting subnational infrastructure investment requires funding and financing 16

3 Innovative funding and financing of subnational government infrastructure 18

$\begin{array}{ll}\text { Opportunities for innovation in infrastructure funding } & 19\end{array}$

Opportunities for innovation in infrastructure financing $\quad 39$

Innovations in investment approaches 52

4 Tackling subnational infrastructure funding and financing challenges 58

Reinforcing subnational government fiscal autonomy and capacity 58

Building subnational government investment capacity 59

Enhancing coordination and cooperation among and across levels of government $\quad 60$

Establishing enabling regulatory and legal frameworks 62

$\begin{array}{ll}\text { References } & 64\end{array}$

\section{FIGURES}

Figure 2.1. Subnational public investment in G20 and OECD countries 14

Figure 3.1. Areas for innovation to support subnational government infrastructure investment 18

Figure 3.2. Examples of taxes that may be available to subnational governments 27

Figure 3.3. Examples of user charges and fees that may be leveraged by subnational governments 30

Figure 3.4. Examples of potential subnational government assets 37

Figure 3.5. Subnational government debt by instrument 44

\section{TABLES}

Table 2.1. Breakdown of responsibilities across subnational government levels 


\section{BOXES}

Box 2.1. A definition of funding, financing and investment approaches

Box 3.1. Examples of programmes to optimise the use of existing infrastructure assets: Canada, Guatemala, the United States and Australia

Box 3.2. The use of conditional grants in Indonesia, Canada, and South Africa

Box 3.3. Grants and subsidies for operations and maintenance in Australia, South Africa and Canada

Box 3.4. Grants to support the COVID-19 recovery at a subnational level in the United States, Korea, France and Italy

Box 3.5. Competitive processes to allocate infrastructure grants in Germany, Australia and India

Box 3.6. Regional development funds and infrastructure funds in the European Union and Chile

Box 3.7. Taxes introduced to support infrastructure investment in the United States and France

Box 3.8. Environmental taxes and emissions trading schemes in Spain, Japan and the United States

Box 3.9. User charges and fees in Korea, Italy and Australia

Box 3.10. Overview of land value capture mechanisms

Box 3.11. Transferable development rights in Brazil and India

Box 3.12. Development impact charges in India, United Kingdom, Canada and Germany

Box 3.13. Land value capture mechanisms in Colombia

Box 3.14. The Asset Recycling Initiative in Australia

Box 3.15. Land valuation in India

Box 3.16. Low-interest loans in Bulgaria, Colombia and the United States

Box 3.17. Green Urban Financing and Innovation Project in China

Box 3.18. Electric bus leases in Shenzhen, China

Box 3.19. Municipal bonds in the United States and local government bonds in Japan

Box 3.20. Green and social bond issuance by subnational governments in France, Spain, Russia and the United States

Box 3.21. UNOPS Sustainable Investments in Infrastructure and Innovation (S3I) initiative

Box 3.22. Subnational pooled finance mechanisms in New Zealand, Japan, France, the United States and India

Box 3.23. National infrastructure banks and funds in Indonesia, Argentina and the United Kingdom

Box 3.24. The Natural Capital Financing Facility (NCFF)

Box 3.25. Crowdfunding and crowd-investing platforms in the United Kingdom

Box 3.28. Municipal government cooperation and national government support for the use of PPPs in Mexico and India

Box 4.1. City deals and contracts in the United Kingdom, the Netherlands and France

Box 4.2. Inter-municipal cooperation for joint infrastructure projects in Brazil, the Netherlands and France

Box 4.3. Public-private partnership legal frameworks in the Commonwealth of Virginia 


\section{Executive summary}

Subnational governments - state, regional, and local - are major infrastructure investors, responsible for almost $60 \%$ of public investment in G20 countries. In many countries, they have primary responsibility for essential public infrastructure and service provision, including for water, waste, education, healthcare and transport. These governments are well placed to design and implement placebased policies that respond to local needs, match citizens' preferences and help address global challenges at a local level.

Subnational government infrastructure investment needs to be future-proof to support an inclusive, sustainable and resilient COVID-19 recovery. The COVID-19 crisis, and subsequent social and economic crises, have revealed and exacerbated spatial disparities in infrastructure and services. The crisis has also accelerated awareness of, and momentum on, the need to act on climate and demographic challenges and address digital divides. Current fiscal stimuli, much of which are being used to support infrastructure investment by subnational governments, need to align with long-term policy objectives and should avoid locking-in carbon-intensive infrastructure that will exist long into the future.

Unlocking private finance requires clear sources of funding and a whole-of-life view of infrastructure costs. While much attention has been paid to the importance of mobilising private finance (bonds, loans, etc.), this report calls for focus on securing both financing and funding (taxes, user charges, asset revenues, etc.) resources. Subnational governments need to have sufficient funding available for the entire lifecycle of infrastructure, including for construction, operations, maintenance and the repayment of finance. Identifying whole-of-life funding sources when making an investment can ensure infrastructure will be well operated and maintained, and, critically, it can improve access to finance.

To increase infrastructure investment, subnational governments can look to innovate in the type and use of funding and financing instruments. What is considered an innovation depends on national and local contexts, and current practices. Indeed, while some of the funding and financing innovations for subnational governments highlighted in this paper may be common-practice in some countries, they may be innovative, or not widely understood, in others. To foster greater awareness across subnational governments, this paper highlights six areas of innovation related to funding and five areas related to financing, drawing on examples from G20, OECD and non-OECD countries (see Figure A).

The paper also highlights two 'investment approaches' that subnational governments can adopt to undertake infrastructure investments. In this report, the 'investment approach' refers to the method by which an infrastructure investment is undertaken. The two approaches detailed in this report are the use of state-owned enterprises (SOEs) and public-private partnerships (PPPs) - a third approach, the use of traditional public procurement is not covered. The choice of investment approach is largely independent from the choice of funding and financing instruments. A traditional public procurement can be financed privately through a green bond, while a PPP can be supported by significant public funding. 
Essential framework conditions need to be in place to unlock the use of funding and financing instruments and support subnational government infrastructure investment. As highlighted by the Recommendation of the OECD Council on Effective Public Investment Across Levels of Government, framework conditions need to be in place to support quality infrastructure investment at all levels of government. These conditions relate to (i) the fiscal space and financial capacity of subnational governments; (ii) the investment capacities within subnational governments, including having sufficient human resources with appropriate expertise; (iii) the coordination and cooperation mechanisms among and across levels of government, including inter-municipal cooperation mechanisms to ensure investment is undertaken at the right scale; and (iv) the regulatory and legal frameworks, which are required to use certain funding and financing mechanisms or investment approaches. As public investment is a shared responsibility across levels of government, policy actions need to be coordinated across levels of government to support quality infrastructure investment.

This paper demonstrates a continued need to focus on the specific challenges and opportunities relating to subnational government infrastructure investment. This report highlights that focusing on funding and financing innovations and the framework conditions for subnational governments can help to unlock infrastructure investment.

Figure A. Areas for innovation to support subnational government infrastructure investment

\begin{tabular}{|c|c|c|c|}
\hline \multicolumn{2}{|c|}{ Funding } & \multicolumn{2}{|c|}{ Financing } \\
\hline \multicolumn{2}{|c|}{$\begin{array}{l}\text { Unlocking funding through better } \\
\text { management and use of existing } \\
\text { infrastructure and budget resources }\end{array}$} & \multicolumn{2}{|c|}{$\begin{array}{l}\text { Supporting access to finance through } \\
\text { credit enhancement programmes }\end{array}$} \\
\hline \multicolumn{2}{|c|}{$\begin{array}{l}\text { Harnessing grant and subsidy } \\
\text { programmes }\end{array}$} & \multicolumn{2}{|c|}{$\begin{array}{l}\text { Exploring new forms of } \\
\text { loans and financial leases }\end{array}$} \\
\hline \multicolumn{2}{|c|}{ Identifying tax revenue opportunities } & \multicolumn{2}{|c|}{ Expanding the use of bonds } \\
\hline \multicolumn{2}{|c|}{$\begin{array}{l}\text { Adopting user charges and fees, while } \\
\text { maintaining accessibility }\end{array}$} & \multicolumn{2}{|c|}{ Increasing the impact from equity } \\
\hline \multicolumn{2}{|c|}{ Capturing increases in land value } & \multicolumn{2}{|c|}{$\begin{array}{l}\text { Diversifying the investors in } \\
\text { subnational government infrastructure }\end{array}$} \\
\hline \multicolumn{4}{|c|}{$\begin{array}{l}\text { Leveraging income from } \\
\text { existing assets }\end{array}$} \\
\hline \multicolumn{4}{|c|}{ Investment approaches } \\
\hline \multicolumn{2}{|c|}{$\begin{array}{c}\text { Harnessing subnational state-owned } \\
\text { enterprises (SOEs) }\end{array}$} & \multicolumn{2}{|c|}{$\begin{array}{l}\text { Adopting subnational public-private } \\
\text { partnerships (PPPs) }\end{array}$} \\
\hline \multicolumn{4}{|c|}{ Framework conditions } \\
\hline $\begin{array}{l}\text { Reinforcing } \\
\text { subnational } \\
\text { government fiscal } \\
\text { autonomy and } \\
\text { financial capacity }\end{array}$ & $\begin{array}{c}\text { Enhancing } \\
\text { coordination and } \\
\text { cooperation among } \\
\text { and across levels of } \\
\text { government }\end{array}$ & $\begin{array}{l}\text { Building subnational } \\
\text { government } \\
\text { investment } \\
\text { capabilities }\end{array}$ & $\begin{array}{l}\text { Establishing enabling } \\
\text { regulatory and legal } \\
\text { frameworks }\end{array}$ \\
\hline
\end{tabular}




\section{Areas for innovation to unlock subnational government infrastructure investment}

This report presents common and innovative instruments that subnational governments use to support infrastructure investment. The applicability of particular instruments for a jurisdiction will depend on the local context, subnational government budgets, fiscal frameworks and local financial markets, among many other areas. Instruments should be considered on a case-by-case basis and be supported by sound fiscal frameworks and transparent practices.

\section{Areas for innovation relating to funding}

Funding helps to pay for new infrastructure investment and is required to meet the ongoing costs for operations, maintenance and the repayment of finance. Demonstrating secure flows of funding over the lifecycle of an investment can also help to mobilise private finance.

Areas for innovation relating to funding subnational government infrastructure:

1. Unlocking funding through better management and use of existing infrastructure and budget resources: This involves maximising the whole-of-life value provided by existing infrastructure, reducing lifetime expenditure requirements and identifying savings from within existing budget resources, which can improve the long-term financial capacity of subnational governments without requiring new revenue sources. Examples feature improved approaches for subnational government asset management, the use of existing infrastructure for new purposes and the use of technology to increase the capacity of assets.

2. Harnessing grant and subsidy programmes: This involves increasing the impact arising from grants and subsidies provided to subnational governments using approaches that support efficient allocation of central government funding. Examples highlight the use of competitive grant processes, regional development funds and COVID-19 economic recovery grants. Among G20 countries, grants and subsidies represent $47 \%$ of total subnational government revenue, versus $51 \%$ globally.

3. Identifying tax revenue opportunities: This includes directing tax revenues to support infrastructure investment, and identifying new forms of taxes, when appropriate. Examples include the hypothecation of tax revenue to investment and the use of environmental taxes. Among G20 countries, taxes represent $39 \%$ of total subnational government revenue, versus $33 \%$ globally.

4. Adopting user charges and fees, while maintaining infrastructure accessibility: This includes strengthening the link between the beneficiaries of infrastructure and the payment for that infrastructure, while compensating the potential reduced accessibility for lower socio-economic groups (e.g. adopting tiered charges and fees). Examples include road user charges, congestion charges and waste charges. Among G20 countries, and globally, user charges and fees represent $9 \%$ of total subnational government revenue.

5. Capturing increases in land value: This involves capturing windfall gains arising from public infrastructure investment or land use changes to pay for the infrastructure investment. In some cases, payments can be in-kind through private infrastructure provision. Examples include developer obligations and charges for development rights, among other areas.

6. Leveraging existing assets: This includes increasing the long-term value generated from subnational government assets through better financial management of assets or the repurposing of assets. Examples include asset leasing and 'Asset Recycling' programs, where proceeds from asset sales are used to support new investment. 


\section{Areas for innovation relating to financing}

In G20 countries, subnational governments account for approximately $20 \%$ of total government debt There are, however, substantial variations in the level of subnational government debt across countries and jurisdictions. In the context of the increased fiscal pressure created by the COVID-19 crisis, the use of financing instruments by subnational governments should be considered on a case-by-case basis. It should be transparent and supported by sound fiscal frameworks to manage the longer-term implications of debt and ensure fiscal stability and budget sustainability.

Areas for innovation relating to financing subnational government infrastructure:

1. Supporting access to finance through credit enhancement programmes: This includes programmes that seek to improve access to, and the terms of, subnational government borrowing. This includes guarantees to support subnational government borrowing from national governments or international institutions, which are usually supported by robust risk management frameworks.

2. Exploring new forms of loans and financial leases: This includes innovations in the form of loans and leases available to subnational governments. Examples include low-interest loans, subordinated loans and green loans. Low-interest (below market rate) loans from a multi-lateral or national financial institution transfer risk from the investment project to the financial institution, which can encourage other investors to support a project. Among G20 countries, loans represent $40 \%$ of subnational government outstanding debt, versus $57 \%$ globally.

3. Expanding the use of bonds: This includes the use of bonds by subnational governments, which is a source of borrowing that is underutilised or unavailable for subnational governments in many countries. The expanding use of bonds by subnational governments should go hand-in-hand with a robust fiscal framework and enhanced subnational public finance management, particularly in the context of increased levels of debt in OECD and G20 countries. Examples in this section include municipal bonds, as well as green, climate, social and 'mini' bonds. Among G20 countries, bonds represent $27 \%$ of subnational government outstanding debt, versus $12 \%$ globally.

4. Increasing the benefits from equity financing through impact investing: This includes increasing and measuring the long-term economic, social and environmental impact from investments in infrastructure projects, which can help to attract equity finance and improve outcomes from investments. One example is the emerging use of 'impact investing' for infrastructure. Equity investment in subnational government infrastructure mainly occurs in public private partnerships.

5. Diversifying the investors in subnational government infrastructure: This includes expanding the providers of finance for subnational governments, which can help to increase access to finance, improve financing terms and may be provided with specialist expertise to support subnational governments prepare projects. Examples include the use of national infrastructure banks, subnational pooled finance mechanisms and crowd-investing. 


\section{Introduction}

Subnational governments - state, regional and local governments - are important infrastructure investors. In recent decades, subnational governments have received additional spending responsibilities through decentralisation processes, increasing their ability to respond to local needs through place-based policy and infrastructure investments (OECD, 2019 $\left.{ }_{[1]}\right)$. The Recommendation of the OECD Council on Effective Public Investment Across Levels of Government (OECD, 2019[2]; OECD, 2014[3]) highlights that public investment is a shared responsibility and that coordination among levels of government is essential. Regions and municipalities, in coordination with national governments, have a fundamental role to help fill the global infrastructure investment gap, can help to meet long-term economic, environmental and social objectives and can support the COVID-19 recovery.

Global infrastructure needs are significant. Before the COVID-19 crisis, the OECD estimated that between 2016 and 2030, approximately USD 95 trillion in public and private investments would I be needed in energy, transport, water and telecommunications infrastructure at global level to sustain growth (OECD, 2017[4]). This equals approximately USD 6.3 trillion per annum, without taking into account the additional climate or social infrastructure needs associated with commitments to achieve the Sustainable Development Goals (SDGs) and the Paris Agreement.

Subnational governments face long-term challenges to provide and maintain quality infrastructure. Many cities and regions have large infrastructure needs, which are often linked to mega-trends such as urbanisation, climate change, digitalisation and demographic shifts. The world population living in cities, high-density places of at least 50000 inhabitants, was 3.5 billion in 2015 and is projected to reach 5 billion (55\% of the world population) by 2050 (OECD/European Commission, 2020 ${ }_{[5]}$ ). Among G20 countries, the share of urban population ranges from $34 \%$ in India to $91.9 \%$ in Argentina (Istituto Affari Internazionali, $\left.2021_{[6]}\right)$. This urbanisation creates a large need for new and upgraded infrastructure in many cities. At the same time, many regions are experiencing population decline. In OECD countries, 57\% of regions are expected to shrink in population by 2050 (OECD, 2019 $\left.{ }_{[7]}\right)$. The decreasing population and tax base in these regions creates fiscal pressure to maintain existing infrastructure and fund new infrastructure. Mega-trends also create a need to strengthen infrastructure resilience and maintenance, as highlighted in a recent OECD report submitted to the G20 (2021 $\left.{ }_{[8]}\right)$.

The COVID-19 crisis highlights the need for subnational governments to invest in green, digital and health infrastructure and increase infrastructure maintenance. The pandemic has revealed regional disparities in access to digital and health infrastructure, in particular between urban and rural regions (OECD, 2021[9]). During the recovery, subnational governments have been at the centre of delivering economic recovery investment packages to help address infrastructure gaps across places (OECD, $\left.2021_{[10]}\right)$. The COVID-19 crisis has also highlighted the need for place-based approaches for infrastructure investment, given the different needs and priorities across regions and cities. These priorities include infrastructure maintenance and the upgrade of certain type of infrastructure in some regions, such as increasing digital connectivity in remote rural areas

Infrastructure investment during the recovery should align with longer-term environmental and social policy objectives, including on addressing climate change. COVID-19 recovery programmes present a significant opportunity for governments - at all levels - to leverage infrastructure investments to achieve long-term objectives. To seize this opportunity, stimulus packages should be designed to orient 
investment towards infrastructure that can accelerate the green transition, and improve resilience to future shocks and climate change. They should also avoid locking-in carbon-intensive infrastructure long into the future, which would hinder the ability to achieve longer-term climate policy objectives (OECD, 2021 [11]). Investment in energy efficient buildings and in the maintenance of existing infrastructure, for example, can successfully support jobs and economic activity in the construction sector, while contributing a lower emission future.

Innovative infrastructure funding and financing mechanisms are needed to increase subnational government investment. Funding and financing can help address the global infrastructure investment gap, while meeting the long-term infrastructure challenges in regions and municipalities, and supporting the COVID-19 recovery. This paper features a range of innovations to support infrastructure development and maintenance during the recovery, and beyond. The paper adopts a broad definition of innovation. While many innovative mechanisms already exist in some countries, they are often not be commonly used by regional and local governments, or are under-developed. This paper highlights examples where subnational government have effectively adopted mechanisms tailored to their local contexts and needs. This paper:

- Defines the role of subnational governments in infrastructure investment, highlights key investment challenges, and outlines the role of funding and financing to support investment (Chapter 2)

- Examines the innovative use of infrastructure funding and financing mechanisms, as well as investment approaches adopted by subnational governments, with examples from G20 and OECD countries (Chapter 3 )

Details four areas to improve the framework conditions and enabling environment so that subnational governments can better leverage infrastructure funding and financing, and can effectively implement infrastructure investments (Chapter 4). 


\section{Subnational infrastructure investment for the COVID-19 recovery and beyond}

\section{Subnational governments are important infrastructure investors}

Subnational governments are providers of core public services and public infrastructure in many countries. Subnational government responsibilities cover many infrastructure-related areas, including education, transport, local utilities, environment, health, culture and housing (Table 2.1). They are key providers of both economic (transport, utilities, etc.) and social (education, health, cultural, etc.) infrastructure, much of which provides an essential public service at a low cost, or free, for users. The OECD-UCLG World Observatory on Subnational Government Finance and Investment $\left(2019_{[12]}\right)$ highlights that, in G20 countries, public investment carried out by subnational governments accounts for $59 \%$ of total public investment and $1.9 \%$ of GDP (Figure 2.1) (OECD, 2021 [13]; OECD/UCLG, 2019[14]) ${ }^{1}$. In addition, subnational governments play a crucial role in environment and climate related services and investment, and are responsible for $64 \%$ of this type of investment in OECD countries (OECD, 2019 $\left.{ }_{[15]}\right)$.

Table 2.1. Breakdown of responsibilities across subnational government levels

\begin{tabular}{|c|c|c|}
\hline Municipal level & Intermediary level & Regional level \\
\hline $\begin{array}{l}\text { - } \quad \text { Education (nursery, pre- } \\
\text { - } \quad \text { Urban planning } \\
\text { - } \quad \text { Local utilities (water, sewerage, } \\
\text { waste) } \\
\text { - } \quad \text { Local roads and public transport } \\
\text { - } \text { Primary and preventative } \\
\text { - } \quad \text { Realthcare } \\
\text { - } \quad \text { Culture centres } \\
\text { - } \quad \text { Public order and safety } \\
\text { - } \quad \text { Environment } \\
\text { - } \quad \text { Local economic development }\end{array}$ & $\begin{array}{l}\text { Specialised and more limited } \\
\text { responsibilities of supra-municipal } \\
\text { interest, with an important role to } \\
\text { assist small municipalities. } \\
\text { - } \quad \text { Education (Secondary or } \\
\text { - } \quad \text { Specialised education) } \\
\text { - } \quad \text { Welfare } \\
\text { - Secondary healthcare } \\
\text { - Waste collection and } \\
\text { - } \quad \text { Treatment } \\
\text { - } \quad \text { and public transport) } \\
\text { Environment }\end{array}$ & $\begin{array}{ll}\text { - } & \text { Education (secondary/higher) } \\
\text { - } & \text { Spatial planning } \\
\text { - } & \text { Regional economic } \\
\text { - } & \text { development } \\
\text { Health (secondary care and } \\
\text { - } \\
\text { hospitals) } \\
\text { Regional roads and public } \\
\text { - } \quad \text { Culture, heritage and tourism } \\
\text { - } \quad \text { Environmental protection } \\
\text { - } \quad \text { Social housing } \\
\text { - } \quad \text { Public order and safety } \\
\text { (regional police) }\end{array}$ \\
\hline
\end{tabular}

Source: Adapted from (OECD, 2019[1])

\footnotetext{
${ }^{1}$ In this paper, all figures on G20 countries are unweighted averages and do not include Saudi Arabia as data are not available. For data on public investment and revenues, all the data for OECD/G20 countries are from 2019, including European Union, while data for G20 non-OECD countries (Argentina, Brazil, China, India, Indonesia, Russia, and South Africa) are from 2016. Data for subnational debt and property tax for all G20 countries are from 2016.
} 
Infrastructure responsibilities can be shared among levels of government and across neighbouring jurisdictions (i.e. for major transport roads or water networks). While national governments (and the European Union for EU countries) contribute significant funding to support subnational government investment through capital transfers, subnational governments often have a core responsibility to design and undertake investments. In relation to infrastructure investment, this responsibility might include land use and infrastructure planning, community consultation, managing building rules and regulations, procurement, contract management and infrastructure operations, amongst many other areas.

\section{Figure 2.1. Subnational public investment in G20 and OECD countries}

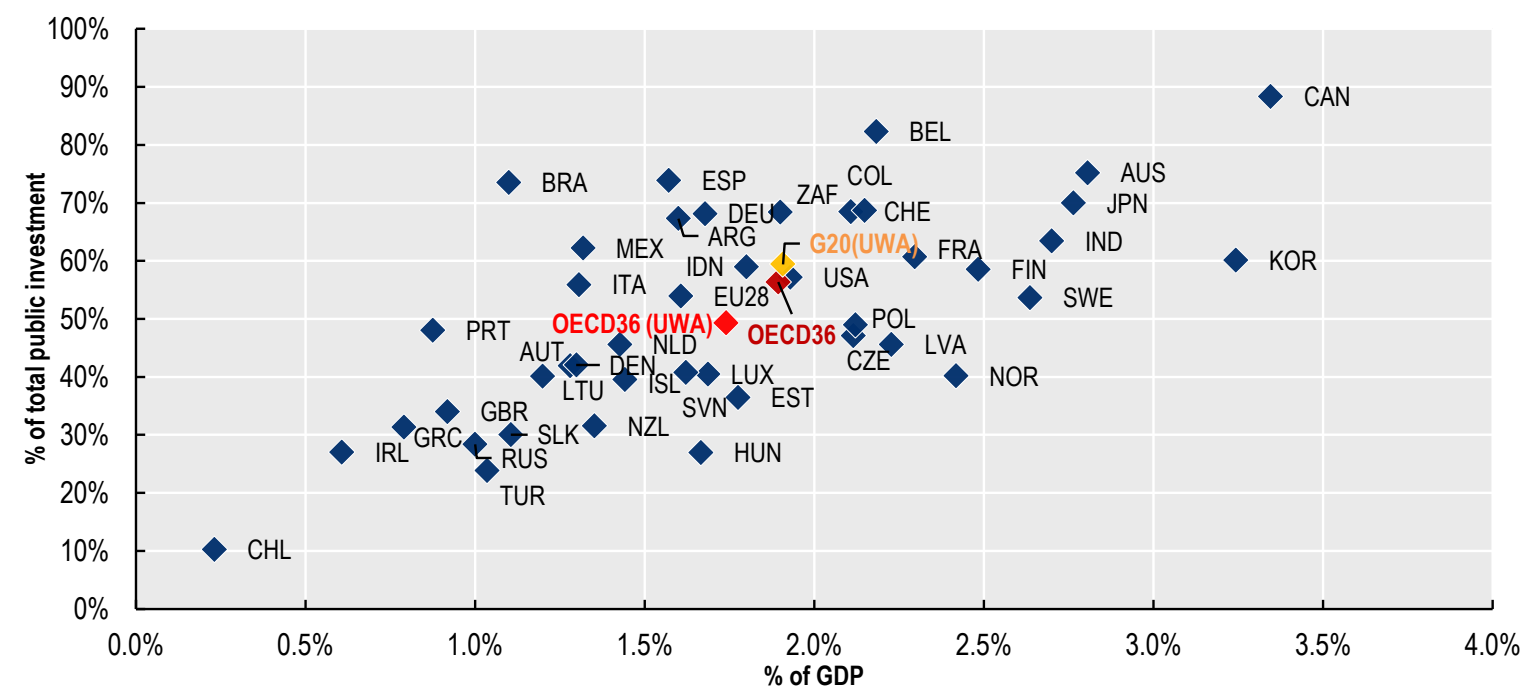

Note: 1. Data for People's Republic of China and Saudi Arabia are not available. 2. Data for Israel are excluded since direct investment by the central government is carried out by public companies and not recorded in General Government Expenditure, thus the share of subnational public investment in total public investment is overestimated. Subnational public investment in Israel accounted for $1.4 \%$ of GDP. 3. Data for G20 (non-OECD) countries are from the year of 2016; data for Chile, Japan, New Zealand and Turkey are from 2018; others are from 2019. 4. EU 28 data are weighted averages of EU 28 countries in 2019.

Source: (OECD, 2021[13]; OECD/UCLG, 2019[14])

The role of subnational governments, and their ability to invest in infrastructure, depends on the level of fiscal decentralisation and the framework conditions in a country (OECD, 2019[2]). Framework conditions are defined by upper-level governments (national and regional) and can specify service or infrastructure provision responsibilities, as well as rules on the use of funding and financing to meet those responsibilities. They can also outline formal coordination mechanisms between governments - as responsibilities for infrastructure are often shared, coordination is essential. The joint responsibility for infrastructure investment is acknowledged in the OECD Recommendation of the OECD Council on Effective Public Investment Across Levels of Government (OECD, 2019 $9_{[2]}$ ) and the Recommendation of the OECD Council on the Governance of Infrastructure (OECD, 2020[16]).

\section{Regions and cities face different infrastructure challenges}

Given the important role of subnational governments in infrastructure investment, it is critical to understand the challenges that these governments face in addressing the infrastructure needs of regions and cities. Three particular challenges are (i) differences in the availability, accessibility and quality of existing infrastructure across regions; (ii) different future infrastructure needs of regions; and, (iii) the fiscal capacity of subnational governments to invest. 


\section{Differences in the availability, accessibility and quality of existing infrastructure}

Many regions within countries do not have access to high quality infrastructure. In developing countries, the challenge is immense. Over 940 million people lack access to clean and safe sources of drinking water and 2.4 billion lack improved sanitation facilities (Rozenberg and Fay, 2019 $9_{[17]}$. The challenge is also large in developed countries. In the United States, for example, the average quality of infrastructure has been graded as 'C-' ("Mediocre, requires attention") by the American Society of Civil Engineers (ASCE, 2021 ${ }_{[18]}$ ) and almost one in 10 bridges are structurally deficient (OECD, 2017 $[19])$. Infrastructure grades assigned by the ASCE, however, vary significantly across states and categories of infrastructure, highlighting different infrastructure challenges for different subnational governments within the same country.

The COVID-19 crisis has further revealed disparities in infrastructure accessibility among regions, particularly for digital and health care infrastructure between urban and rural regions (OECD, 2021 [9]; OECD, $2021_{[20]}$ ). While $85 \%$ of urban households had access to fast broadband before the crisis across OECD countries,, only $56 \%$ of rural households had similar access (OECD, $2021_{[9]}$ ). Similarly, the number of hospital beds per capita has decreased in rural regions, especially those far from large cities, in the past two decades. In 2018, metropolitan regions had $65 \%$ more hospital beds per capita than remote regions, a gap which can affect their ability to cope with a health crisis (OECD, 2020[21]; OECD, 2021 [22]).

\section{Regions and cities do not have the same infrastructure investment needs}

Differences in infrastructure investment needs across regions and cities is linked to population and demographic shifts. Many urban areas, particularly in emerging economies, face rapid urbanisation, which requires significant new infrastructure investment, including for housing, public transport, local roads, utilities, schools, hospitals and digital infrastructure. The population living in cities, high-density places of at least 50000 inhabitants, was 3.5 billion in 2015 and is projected to reach 5 billion (almost $55 \%$ of the world population) by 2050 (OECD/European Commission, 2020 [5] ). This creates a significant need to build new infrastructure in urban areas, while also maintaining and upgrading existing infrastructure. At the same time, many rural and remote regions are affected by demographic shifts, such as ageing populations and outmigration. Across 29 OECD countries with data available, $57 \%$ of regions are expected to shrink by 2050 (OECD, 2019 $[7]$ ). This can reduce investment needs and decrease the tax base to fund maintenance activities. Demographic changes also result in different infrastructure needs. Over the coming decades, infrastructure and services linked to ageing (such as aged care centres and clinics) will disproportionally increase in rural regions compared to metropolitan regions due to aging in many rural areas (OECD, 2021 [22]).

Post-COVID-19, governments at all levels need to be more flexible and adaptable, and rethink the types of infrastructure needed in regions and cities. It will be necessary to re-examine the impact of megatrends, while also ensuring that COVID-19 recovery investments continue to align with long-term priorities. For example, the OECD has highlighted four scenarios of settlement patterns that could emerge after the pandemic due to the increased adoption of remote working (OECD, 2021 $\left.{ }_{[23]}\right)$. These scenarios reveal how changing patterns of work and settlement may impact regional and urban development, with significant implications across a range of policy areas, including for infrastructure. For example, good telecommunications infrastructure will be a critical enabling factor for remote working and access has typically been lower in non-metropolitan regions (in terms of coverage and speed). In addition, central business districts in many cities have experienced high outmigration during COVID-19 (OECD, 2021 [23]), which if sustained, could reduce the need for investment in these areas.

\section{Subnational government infrastructure investment can be affected by economic cycles}

Even before the COVID-19 crisis hit, subnational governments were struggling to balance the high demand for infrastructure investment with insufficient funding. The 2008 global financial crisis and the adoption of 
fiscal consolidation measures from 2010 put a severe strain on subnational finance in general. Subnational public investment was cut back in a majority of OECD countries and took about a decade to recover to the 2008 pre-crisis level.

The COVID-19 crisis has a similar potential to decrease the fiscal space and financial capacity for subnational governments to make investments, at a time when investment and stimulus are most needed. This risk arises from downward pressure on revenue, increased expenditure obligations and constrained borrowing capacity. Given the contraction of self-financing capacities and increasing deficits, there is a high risk that subnational public investment is used as an adjustment variable post-COVID-19 as occurred after the 2008 financial crisis (Allain-Dupré, Hulbert and Vammalle, 2012[24]). While support from central governments softened the early fiscal impact of the crisis on subnational governments, the outlook for 2021 and 2022 is uncertain (OECD, 2021 [9]).

As well as supporting the economic recovery, strengthening subnational public finances is essential to help achieve long-term policy objectives, including the green transition and digital transformation. Almost $70 \%$ of EU municipalities identify that they have limited fiscal capacity to deal with a green transition, while some $43 \%$ do not provide standard digital services (EIB, 2021 ${ }_{[25]}$ ). A lack of funding is one of the principal impediments to municipalities' ability to invest.

Beyond funding, subnational governments can also face obstacles such as the lack of capabilities, an inappropriate scale for investment due to municipal fragmentation or regulatory and legislation constraints on investment (EIB, 2021 ${ }_{[25]}$; OECD, 2014[3]). All of these challenges need to be addressed support investment in regions and cities, and help countries to pursue their public policy goals more effectively (see chapter 4).

\section{Supporting subnational infrastructure investment requires funding and financing}

Many countries, regions and cities have large infrastructure investment gaps (OECD, 2017 $\left.{ }_{[4]}\right)$ and can face difficulties to sufficiently maintain existing infrastructure. Yet, there is potentially a large amount of private finance that is available to support new infrastructure investment (OECD, 2020[26]). This gap between the availability of finance and the amount of infrastructure spending highlights an 'infrastructure investment paradox': although finance is available, infrastructure investment needs are still not being met.

Understand this paradox requires making a distinction between funding and financing. Funding refers to money that is ultimately used to pay for investments, while financing refers to money that may be used to cover upfront investment costs that comes with an obligation for repayment (Box 2.1). The upfront cost of a new rail line, for example, may be paid through a mix of funding (e.g. grants from national governments) and financing (e.g. project finance loans from the private sector), but the ongoing costs, including for operations, maintenance and the repayment of finance, need to be paid from funding sources (e.g. grants from upper-level government and ticket fares).

The use of funding and financing is separate to the 'investment approach' used to undertake infrastructure investment. All investment approaches - both public and private - can leverage a mix of funding and financing mechanisms (OECD, 2015 $\left.{ }_{[27]}\right)$. This paper makes a distinction between the financial elements of a project (funding and financing) and the way that investment is undertaken, the 'investment approach' (Box 2.1). While a traditional public procurement could be privately financed through a green bond, a PPP could be supported by funding from capital grants, alongside loans and equity. 


\section{Box 2.1. A definition of funding, financing and investment approaches}

Funding and financing are inter-related but separate concepts that are important to define when discussing infrastructure investment:

Funding refers to the money that is ultimately used to pay for an investment. Funding may come from government budgeted revenue sources or from user charges paid to a privately-owned infrastructure operator that is operating public infrastructure under a concession. Although user charges collected by a private operator are not on the government balance sheet, they are still a source of funding that pays for public infrastructure. While funding is not required to pay up-front investment costs, it is required to pay the costs from operations, maintenance and the repayment of financing.

Financing refers to money from private or public investors that can pay some or all up-front investment costs. Financing can take the form of debt (loans and bonds) or equity. Financing always comes with an obligation for repayment over an agreed period in the future and has to be paid for by funding.

Investment approach refers to the method or delivery approach that is used to harness funding and financing to support new infrastructure investment. Approaches range from the public provision of infrastructure, using traditional public procurement or state-owned enterprises, through to public-private partnerships (PPPs) or the regulated private provision of infrastructure.

One important explanation for the 'infrastructure investment paradox' is that the limit on subnational government infrastructure investment is due to a lack of funding. This is particularly relevant for local governments with low fiscal autonomy, as they may have limited ability to increase revenues to fund new investment. Although financing can help to meet upfront costs, and is useful to spread investment costs over time, financing also creates a future need for funding. Many investors will be unlikely to finance an infrastructure investment where there is insufficient, or unclear, sources of funding to repay financing. Where private financing relies on forecast funding that does not materialise, infrastructure finance can become a financial liability for governments, particularly if a revenue guarantee is provided.

The lack of funding for infrastructure may also help to explain why maintaining subnational government infrastructure is such a challenge. Where future infrastructure maintenance costs are not properly accounted for in the planning phase, and subnational governments do not have sufficient spare funding capacity, investment can create a long-term fiscal burden. In some cases, this challenge could be exacerbated by political cycles and incentives, which may reduce the focus on longer term fiscal implications of investments. As a result limited funding may be available for infrastructure maintenance and operations, and long term budget pressures could be created for subnational governments. Given this, governments at all levels should ensure that funding sources are available to support the entire infrastructure lifecycle when planning investments. 


\section{Innovative funding and financing of subnational government infrastructure}

Funding and financing are essential to support infrastructure investment in regions and cities. Although many potential instruments exist, subnational governments are often challenged to access funding and financing to support a desired level of infrastructure investment. This chapter of the report highlights a range of funding and financing instruments. While some of these instruments are common practice, some subnational governments have limited experience with these instruments in their local context. This paper seeks to highlight how both common place and innovative instruments are being used in new and innovative ways by subnational governments.

The chapter examines six main areas for innovation relating to funding and five main areas for innovation relating to financing (Figure 3.1). It also highlights two key investment approaches used by subnational governments: subnational public private partnerships (PPPs) and subnational state-owned enterprises (SOEs). The paper provides an overview of the main instruments available to subnational governments and outlines examples to illustrate innovative practices at a subnational level in G20, OECD and nonOECD countries. These examples can provide inspiration to policymakers.

Innovative funding and financing instruments should be adopted to support subnational governments on a country-by-country or case-by-case basis. Not all instruments or innovations are appropriate for all types of infrastructure, or for all levels of government. In some countries or regions, it may not be relevant, appropriate, or feasible to implement some of these funding or financing mechanisms for subnational infrastructure. Instruments should be further evaluated for use in a local context.

Figure 3.1. Areas for innovation to support subnational government infrastructure investment

\begin{tabular}{|c|}
\hline Funding \\
\hline $\begin{array}{c}\text { Unlocking funding through better } \\
\text { management and use of existing } \\
\text { infrastructure and budget resources } \\
\text { Harnessing grant and subsidy } \\
\text { programmes }\end{array}$ \\
\hline Identifying tax revenue opportunities \\
\hline Adopting user charges and fees, while \\
maintaining accessibility \\
\hline Capturing increases in land value \\
\hline Leveraging income from existing \\
assets
\end{tabular}

\begin{tabular}{|c|}
\hline Financing \\
\hline $\begin{array}{c}\text { Supporting access to finance through } \\
\text { credit enhancement programmes }\end{array}$ \\
\hline $\begin{array}{c}\text { Exploring new forms of loans and } \\
\text { financial leases }\end{array}$ \\
\hline Expanding the use of bonds \\
\hline Increasing the impact from equity \\
\hline Diversifying the investors in \\
subnational government infrastructure \\
\hline
\end{tabular}




\section{Opportunities for innovation in infrastructure funding}

Funding sources are required to pay for infrastructure investment, operations, maintenance and the repayment of finance. This section provides an overview of six main areas of innovation types of funding to support subnational government investment.

\section{Better management and use of existing infrastructure assets}

Innovations relating to the use and management of existing infrastructure and budget resources can maximise the whole-of-life value provided by infrastructure, reduce life-time infrastructure expenditure and avoid a need for new revenue sources. This can help to improve the long-term financial capacity of subnational governments.

Maintenance spending to support existing assets represents a large share of subnational government infrastructure expenditure. Approximately $70 \%-85 \%$ of the costs of an asset are incurred after the asset is bought or built (United Nations, $2021_{[28]}$ ). In European municipalities over the past three years, for example, maintenance and repair was the largest infrastructure spending area (almost $40 \%$ of budgets), followed by modernisation and adaptation of existing infrastructure (35\%) and new investments (30\%) (EIB, 2021 [29]).

Infrastructure maintenance has a large number of benefits, and is often the responsibility of regional and local governments, but can be underfunded. The Italian G20 Presidency Policy Agenda on Infrastructure Maintenance highlights that adequate planning, funding and implementation of infrastructure resilience and maintenance along the entire life of existing assets is a critical, and urgent, priority for many countries (Italian G20 Presidency, 2021 [30]; OECD, 2021 [8]). In developing countries, for example, losses in sales due to power outages amount to USD 82 billion per year and the reduced utilisation of transportation due to disrupted infrastructure causes a loss of USD 107 billion per year (World Bank Group, 2021 [31]). In the United States, the case for maintenance investment has been argued to be "overwhelming" (Brookings, $2017_{[32]}$. Studies indicate that an optimal level of maintenance can increase a country's growth rate, provide high returns on investment, and have a positive impact on productivity and economic growth (Rioja, 2012[33]). Maintenance may also reduce the need for future investment and prevent catastrophic events, which can result in high social, economic and environmental costs.

In line with the OECD Recommendation on Governance of Infrastructure, subnational governments should make sure that infrastructure assets perform throughout their entire lifecycle (OECD, 2020[16]). This involves maximising the whole-of-life financial and social value of infrastructure, including by properly maintaining and managing infrastructure assets. The United Nation (UN) handbook for local and national governments on managing infrastructure assets for sustainable development provides practical advice to all levels of government on asset management, which is essential to maintain infrastructure (United Nations, 2021 [28]).

Beyond the improved use of assets, governments can look to identify savings from within existing budget resources to support new investments. Improving the use of existing budget resources provides a way to fund new investments without requiring new revenue sources. Among other areas, this can involve better aligning capital planning to long-term priority areas (McKinsey, 2017[34]), better integrating planning and budget functions (Allen et al., 2020[35]), or seeking economies of scope when planning investments. This can be particularly challenging and important in places where the population is declining or ageing, which can create acute pressures for subnational government finances (OECD, 2016 $\left.{ }_{[36]}\right)$.

Opportunities for better using existing assets include harnessing of data to better identify asset management priorities, involving communities in identifying infrastructure needs, increasing the value provided by assets and, in some cases, improving the management of assets through the use of subnational SOEs. The OECD Compendium of Policy Good Practices for Quality Infrastructure Investment 
$\left(2020_{[37]}\right)$ recognises the importance of optimising lifecycle costs and asset quality by ensuring effective monitoring, operation and maintenance. It highlights that governments at all levels can empower infrastructure and regulatory authorities to collect data on asset conditions and maintenance needs. This can allow them to set performance indicators to ensure that service levels do not deteriorate and that sufficient funding is assigned to maintenance and replacement activities. In the Rebuilding Ontario plan, for example, the Ontario Government in Canada is improving asset data and analytics for better asset management. In Guatemala City, the government is using 'demand-based asset management', where the community can identify infrastructure needs. In Arizona, United States, a Smart Highway Corridor Program proposes increasing value created from highway corridors by installing state-owned broadband networks along the same corridor (Box 3.1). In Victoria, Australia, the government invested in a ramp metering system to significantly increase the capacity of highways. There may also be opportunities for subnational governments to leverage SOEs to help manage existing assets. Subnational governments sometimes bundle existing and new assets in a dedicated SOE, which might support efficient management of public assets (see section on subnational SOEs).

\section{Box 3.1. Examples of programmes to optimise the use of existing infrastructure assets: Canada, Guatemala, the United States and Australia}

\section{Rebuilding Ontario: an infrastructure plan for the people}

Ontario, Canada owns more than CAD 230 billion of infrastructure assets. To "maximise the life, performance and value of existing infrastructure and services", the Ontario government implemented the Rebuilding Ontario plan in 2019. Key elements of the plan include the collection of quality data, increased integrated land-use and infrastructure planning, improving planning and procurement, and improving asset management. The plan establishes an interdisciplinary team to share asset management practices, improve data collection and apply advanced analytics to asset portfolios.

\section{Demand-Based Asset Management in Guatemala City}

Guatemala City uses a demand driven approach to help decide local maintenance priorities. Citizens can submit requests to the 22 decentralised district councils for infrastructure repair and improvements. These are integrated into a Future Visions plan for the city. Each district then prepares a separate local plan. A local asset manager in each district is responsible for reviewing identified community infrastructure needs, checking that resources are available and supervising investments.

\section{Smart Highway Corridor Program, Arizona, United States}

This programme intends to leverage the existing highway network to also provide broadband infrastructure, highlighting how an existing asset can be optimised to expand its use and value. In January 2020, the Governor of Arizona announced plans to spend USD 50 million to install broadband conduit and fibre optic cable along designated highways in the state, which would enable future broadband capacity in rural and tribal areas.

\section{Ramp metering system in Melbourne, Australia}

Ramp metering helps to maintain traffic stability and achieve near-capacity traffic flows by optimising traffic throughput and travel speeds. It involves controlling the number of vehicles entering a highway. After ramp metering was introduced in Melbourne, the number of vehicles during peak increased by 20 per cent, travel speeds improved 20-30 per cent and crash rates dropped by 30 per cent on the same width of highway. This technology investment may reduce the need for highway widening. Ramp metering is now being trialled in Denver in the United States.

Source: Ontario (Ontario Government, 2019[38]); Guatemala (Caramazana, 2020[39]); Arizona (Congressional Research Service, 2020[40]); Victoria (Department of Transport, 2021 $\left.{ }_{[41]}\right)$ 


\section{Harnessing grant and subsidy programmes}

\section{Innovations in grant and subsidy programmes can help to increase the benefits from funding provided to subnational governments. Examples include the use of competitive grant processes, regional development funds and COVID-19 economic recovery grants.}

Grants and subsidies are transfers from upper-levels of government (national and regional), international organisations and, in some cases, philanthropy. Among G20 countries, current and capital grants and subsidies represent $47 \%$ of total subnational government revenue, versus $51 \%$ globally (OECD and UCLG, $\left.2019_{[12]}\right)$. In European municipalities, for example, approximately $39 \%$ of total infrastructure funding is from capital transfers (EIB, 2021 [29]). In the United States, the federal government provides $41 \%$ of the funding required to build highways, mass transit, airports, and water infrastructure, and provides $10 \%$ of the required operational and maintenance funding, with the remainder provided by the state and local governments (CBO, 2018[42]).

In some cases, philanthropic grants may provide an alternate source of funding for infrastructure investment. Globally, funding from private philanthropy was valued at approximately USD 8.8 billion in 2019 (OECD, 2019 $\left.{ }_{[43]}\right)$. Although funding from private philanthropy is relatively small compared to total government infrastructure expenditure, it can be particularly important in developing countries. The Urban Climate Change Resilience Trust Fund, for example, is a grant-based fund sponsored by the Rockefeller Foundation, Switzerland and the United Kingdom, that provides grant funding to help make climate change a central element of city planning in eight countries (Asian Development Bank, 2021 ${ }_{[44]}$ ).

Grants and subsidies may be provided based on a defined formula or be targeted support to certain investments or regions. In many countries, they are designed to address differences in fiscal capacity and infrastructure needs across subnational jurisdictions, acknowledging that not all regions have the same fiscal strength, taxpayer base or existing level of infrastructure access. Transfers should be based on a national and regional planning view of infrastructure deficiencies across a long time horizon. In designing transfers, upper-level governments should also ensure that there will be sufficient funds for proper upkeep of these facilities at a subnational level.

Capital grants can be volatile based on economic cycles, meaning that this form of funding may sometimes be difficult for subnational governments to rely on to support future investment. Following the 2008 crisis, for example, capital grants and subsidies were substantially reduced or cut. While in 2020, capital grants in many countries were increased to support the COVID-19 recovery, but this is not the case in all countries (OECD, 2021 [20]). In 2021 and 2022, the risk of grants and subsidies being used as an adjustment variable and reduced, cut or postponed remains (OECD, 2021 $\left.{ }_{[9]}\right)$. This risks prolonging the COVID-19 recovery as subnational governments would have less ability to undertake investment for economic stimulus.

Four areas for innovation relating to grants and subsidies for subnational governments are highlighted in following sub-sections. These include innovations relating to (i) the use of conditions on grants, (ii) the use of grants to support COVID-19 economic recovery, (iii) processes to award grants, and (iv) regional development funds for integrated place-based investment.

\section{The use of conditions on grants and subsidies}

Upper-level government grants and subsidies often have funding conditions attached. These conditions may seek to support equity objectives, address fiduciary and accountability concerns, promote minimum investment standards, or ensure that the use of grants and subsidies are aligned with national and subnational investment priorities (OECD, 2017[45]).

Conditions can include the earmarking of funds to specific categories, programmes, projects or agencies. Earmarked funds are distinct from general purpose grants, which are used discretionally by subnational 
governments and often based on distribution formulas (block grants). Capital grants and subsidies are often earmarked, which can result in less flexibility for subnational governments. Earmarked grants often come with guidelines, stricter controls and reporting obligations, or timeframes for expenditure. Indonesia's Dana Alokasi Khusus (DAK) grants, for example, are earmarked to support capital investment by provincial governments (Box 3.2).

Conditions on grants also include the use of environmental performance requirements, requirements for ex-ante economic evaluation tools, implementation of certain reforms, involvement other governments, and involvement of private sector firms in investment financing or design (OECD, 2017[45]; Shah, 2017[46]). For example, in Canada, environmental conditions were placed on grans through the Climate Lens programme to help meet climate change objectives, and in South Africa, performance conditions are applied to the Urban Settlements Development Grant (Box 3.2).

\section{Box 3.2. The use of conditional grants in Indonesia, Canada, and South Africa}

\section{Earmarking: The Dana Alokasi Khusus grants in Indonesia}

These grants are earmarked for investment spending, especially for capital budget expenditure. Although earmarking helps support new infrastructure investment, there is some evidence that subnational governments are encouraged to invest in new facilities, even where the rehabilitation of existing facilities is a higher priority and may represents a more efficient use of funds, simply because the latter may not always qualify as "capital" expenditure.

\section{Climate grant: The Climate Lens, Canada}

The Climate Lens is a requirement for projects seeking funding through the Investing in Canada Infrastructure Program, Disaster Mitigation and Adaptation Fund, and Smart Cities Challenge. This initiative seeks to encourage consideration of climate impact and low-carbon options in the planning of infrastructure projects. The programme places a condition to undertake a greenhouse gas mitigations assessment and a climate change reliance assessment for certain types of projects.

\section{Performance grant: Urban settlements development grant, South Africa}

This grant is provided to local governments and has three tranches of funding that are released subject to the submission of quarterly and annual performance data, including non-financial performance indicators. Local governments that do not meet certain conditions, such as failing to spend at least $60 \%$ of their grant may have subsequent transfers stopped and reallocated.

Sources: Indonesia (Kim and Dougherty, 2020[47]; Lewis and Smoke, 2017[48]); Canada (Infrastructure Canada, 2021[49]; OECD, 2021 [50]); South Africa (OECD, 2017[45]).

The use of conditions, especially earmarking, should be carefully designed to help achieve objectives and avoid excessive resource burdens. Excessive conditionality could, for example, result in extensive planning requirements and rigidities in budgeting options, undermining the flexibility, and hence the effectiveness and efficiency of local investment spending (Kim and Dougherty, 2020[47]). In some cases, subnational governments may not have the capacity to properly implement conditions or may only cosmetically comply in a way that does not address the underlying objectives (OECD, 2017[45]; GIZ, 2012[51]). Alternative approaches to achieving upper-level objectives exist and can including the use of incentives (i.e. providing additional funding for meeting certain requirements), ensuring baseline conditions in place (such as environmental regulations) or linking conditions to longer term outcomes (OECD, 2017[45]]). When it is necessary to introduce conditionality, these should be kept as few and as simple as possible, with practical guidance (Kim and Dougherty, 2020[47]; Spahn, 2012[52]). 
One particular use of earmarking is to support the operation and maintenance of existing infrastructure. Grants and subsides for operations and maintenance are particularly important where subnational governments or agencies have insufficient 'own-source' revenues. The size of grants funding for infrastructure operations and maintenance varies significantly across countries. In the United States, for example, $10 \%$ of subnational government (state and local) annual operations expenditure is covered by federal grants (USD 26 billion annually out of USD 266 billion) (CBO, 2018[42]). Operations and maintenance grants may be provided through ongoing or one-off programmes. Two examples of ongoing grant programs for subnational government infrastructure are Integrated Urban Development Grants for road maintenance in South Africa, and the Capital Facilities and Maintenance Program in Canada, which supports infrastructure in First Nations communities. An example of a one-off grant for maintenance was the Queensland Government Economic Recovery Strategy in Australia, which was implemented to support the recovery from COVID-19 by directing funding to bring forward existing maintenance programs with the aim to more efficiently and promptly support investment during the recovery (Box 3.3).

\section{Box 3.3. Grants and subsidies for operations and maintenance in Australia, South Africa and Canada}

\section{Queensland Government's Economic Recovery Strategy, Australia}

In May 2020, the Queensland Premier announced AUD 200 million for a COVID Works for Queensland program, to be delivered during 2020-2021. This programme was to support the delivery of jobs by creating new infrastructure and supporting additional maintenance or minor works projects, including bringing-forward planned and budgeted maintenance. Funding was allocated to Local Councils based on population and unemployment levels in the local government areas.

\section{Integrated Urban Development Grant, South Africa}

The Integrated Urban Development Grant is a conditional grant mechanism used by South Africa's national government to provide funding for infrastructure investment for the poor and to promote increased access to municipal own-sources of capital finance for economic infrastructure. It explicitly supports maintenance of road infrastructure to serve the poor, which is a project selection criteria.

\section{Capital Facilities and Maintenance Program, Canada}

The Capital Facilities and Maintenance Programme provides over CAD 1 billion per year for housing, education, water and waste water and other infrastructure to support community infrastructure for First Nations people living on reserve in Canada. One funding stream is dedicated to support operations and maintenance of existing infrastructure. The programme has objectives to maximise the lifecycle of physical assets, mitigate health and safety risks, ensure assets meet applicable codes and standards and ensure assets are managed in a cost-effective and efficient manner. The funding is managed through regional 5-year capital plans.

Source: Queensland, Australia: (Queensland Government, 2021 ${ }_{[53]}$ ); South Africa (National Treasury, Republic of South Africa, 2020[54]); Canada (Government of Canada, 2015[55]).

\section{Grant programmes to support the COVID-19 recovery}

Many national governments have announced large economic recovery packages to support the COVID-19 recovery. These generally focus on public investment through grants to subnational governments. Recovery packages have sought to stimulate employment and economic growth, while maintaining a longer-term focus on three main priority areas: (i) strengthening health systems; (ii) digitalisation; (iii) accelerating the transition to a carbon neutral economy (OECD, 2021 ${ }_{[9]}$ ). 
COVID-19 relief funds have included a range of new and innovative approaches to grants that can support subnational government infrastructure investment in a timely manner. In the United States, the American Rescue Plan included USD 365 billion in direct funding for state, local, tribal and territory infrastructure systems, with higher discretionary flexibility than previous COVID-19 relief funding (Brookings, 2021 [56]). In Korea, the government announced a Korean New Deal, which combines central government, local government and private sector funding to support the recovery. In France and Italy, governments have increased capital grants to subnational government to support the recovery and the align investment with the green transition (Box 3.4).

\section{Box 3.4. Grants to support the COVID-19 recovery at a subnational level in the United States, Korea, France and Italy}

\section{American Rescue Plan, United States}

The American Rescue Plan, adopted in March 2021, included USD 365 billion direct funding for state, local, tribal and territory infrastructure systems. Grants in the plan can pay for capital and operating expenditure. Funding was provided for discretionary use within specific categories of investment, or through a pre-set formula. Among many different elements of the plan, it provided flexible funding to a variety of digital-related activities, including to reduce consumer prices, building network infrastructure, and funding digital skills. For example, USD 13 billion was provided to the Coronavirus Local Fiscal Recovery Fund to support metropolitan cities, local government units and counties to build digital infrastructure, provide broadband subscriptions and implement digital literacy training.

\section{Korean New Deal}

Korea adopted the New Deal to combat the economic setbacks caused by COVID-19, investing KRW 75.3 trillion in installing green technology in outdated government-leased apartments, installing artificial intelligence technology in traffic systems, among other projects. The majority of the spending will be funded by the central government, which will cover KRW 42.6 trillion (57\%), while local governments will match those funds with a total of KRW 16.9 trillion (22\%). The remainder of funding (20\%) will be private sector investments.

\section{COVID-19 recovery in France}

In France, as part of its emergency plan and recovery measures related, the government increased the Support Grant for Local Investment from EUR 600 million to EUR 1.6 billion, placing particular emphasis on investments in the health, environmental transition and heritage preservation. The Recovery Plan also included a package of measures to promote subnational investment geared towards regional development and cohesion (e.g. digital inclusion, expansion of the High-Speed Broadband Plan, etc.).

\section{COVID-19 recovery in Italy}

In Italy, the Budget Law 2020 established new investment funds in the framework of the recovery: Central Government Investment Fund, the Green New Deal Fund, and the Fund for relaunching investments for municipal sustainable infrastructure development. In addition, a "South Plan 2030" was presented to support public investment in southern Italy, with a focus on education, social infrastructure, strengthening Green New Deal commitments in the south and inland areas, developing innovation and strengthening Special Economic Zones. Capital grants have been assigned to municipalities for investment in urban regeneration projects (EUR 8.5 billion in 2021-2034) and for building and land security (EUR 8.8 billion in 2021-2034), as well as to the regions for road and safety measures and for the development of public transport systems (EUR 3.3 billion in 2021-2034).

Sources: United States (CSG, 2021 [57]; Brookings, $2021_{[56]}$; Brookings, 2021 ${ }_{[58]}$ ); Korea (OECD, $2021_{[10])}$; France and Italy (OECD, $2021_{[9]}$ ). 


\section{Competitive processes to help allocate infrastructure capital grants}

Upper-level governments, international organisations and philanthropic organisations sometimes support local infrastructure investment by allocating funds through competitive processes. This requires that subnational governments, agencies or other organisations prepare funding applications (or business cases), which are assessed against pre-defined criteria to allocate funding to the investment priorities with the highest evaluation. Assessments may be undertaken within subnational government agencies, or at arm's length from government, using peer review processes or independent infrastructure assessment authorities (such as with Infrastructure Australia). Undertaking peer review assessments of planned investments can help to ensure that there is a robust evidence-base for investments.

Competitive processes should account for different capabilities and competencies of subnational government to prepare funding applications. Not all governments have the same expertise to prepare high-quality funding requests. To account for this, upper-level governments can provide funding to regions to explicitly support project planning and development, and they can review total investment to ensure that funding is appropriately allocated across regions. Three examples of competitive grant processes are the Smart Cities Pilot Projects in Germany, the National Broadband Network (NBN) Regional Co-investment Fund in Australia and the Smart Cities Mission in India (Box 3.5).

\section{Box 3.5. Competitive processes to allocate infrastructure grants in Germany, Australia and India}

\section{Smart Cities Pilot Projects, Germany}

Established in 2016, the "Smart Cities Pilot Projects" programme supports selected municipalities to foster digitalisation. The programme offers grants based on a competitive process, with total funding of EUR 750 million euros. In 2021, 28 municipalities out of 94 applicants were awarded funding, with approximately EUR 300 million available. Funding was allocated based on a multi-stage review process supported by external experts. Funding is tied to a contribution made by each municipality, which is between 10 and $35 \%$ of the total value, and depends on the financial capacity of the municipality.

\section{NBN Regional Co-investment Fund, Australia}

NBN Co. has developed a dedicated AUD 300 million fund to support Federal, State and local governments and agencies to upgrade digital capacity in regions and remote areas. The fund is administered by NBN Co, which is responsible for developing Australia's national broadband network. The fund co-funds projects based on an assessment against a pre-defined commercial investment benchmarks. The fund is designed to facilitate equitable access by all states and territories, and levels of government, and includes a defined maximum allocation for each state and territory based on a formula related to the investment need.

\section{Smart Cities Mission, India}

The Smart Cities Mission was the first competitive grant programme for cities in India's history. It was launched in 2015 with the objective to promote cities that provide "core infrastructure, clean and sustainable environment and give a decent quality of life to their citizens through the application of "smart solutions'". It is a joint effort of the Ministry of Housing and Urban Affairs, and all state and union territory (UT) governments. The programme is based on a two-stage competition, through which 100 cities were selected for funding. The central government provides financial support of INR 480 million toward the programme, with an equal amount of funding to be provided by State governments. The initiative also seeks to leverage additional resources through innovative finance mechanisms, such as municipal bonds and loans.

Source: Germany (Federal Ministry of the Interior, Building and Community, 2021 [59]); Australia (NBN Co, 2021 [60]; NBN Co, 2021[60]); India (Government of India, 2021[61]). 


\section{Regional development funds}

National governments may establish funds dedicated to support broader regional development objectives, beyond individual infrastructure investments. This approach uses grants to help address multiple, inter-linked and long-term development objectives, which may not be achieved by solely investing in one type or sector of infrastructure. This place-based investment approach may fund and coordinate public and private sector investment across housing, transport, schools and utilities in a defined region, with a focus coordinated investments that support long-term regional or local development. It may also simultaneously support targeted industrial and economic development in a region through enterprise policies.

The European Union and several countries have established regional development funds to support regional investments, including in infrastructure, usually with the objective for balanced territorial development. The European Union (EU) Cohesion Policy, for example, provides funding to the disadvantaged regions to promote regional development across Europe (Box 3.6). In Chile, the Regional Development Fund supports regional development and infrastructure projects across Chile (Box 3.6).

\section{Box 3.6. Regional development funds and infrastructure funds in the European Union and Chile}

\section{European Union funds under the Cohesion Policy}

The Cohesion Policy aims to correct imbalances between countries and regions. During 2014-2020, approximately $32.5 \%$ of the EU budget was allocated to support Cohesion Policy through the European Regional Development Fund (ERDF), European Social Fund (ESF) and Cohesion Fund (CF).

In particular, ERDF invests in infrastructure and services in underdeveloped regions. In 2021-2027, ERDF investments focus on infrastructure investments for innovation and research, for the digital agenda, as well as for the low-carbon economy. As part of the ERDF, all regions and Member States will use at least $8 \%$ of their allocation of funds to support urban development delivered through local development partnerships. Operations under the ERDF are also expected to contribute $30 \%$ of the overall financial envelope to climate objectives.

The Cohesion Fund provides support to subnational governments located in EU Member States with a gross national income (GNI) per capita below $90 \%$ of the EU-27 average (15 EU countries for the 20212027 period). The fund is used to support environment, climate, and trans-European transport network investments to strengthen the economic, social and territorial cohesion of the EU.

In the 2021-2027 Programming period, a new fund was introduced to support the Cohesion Policy - the Just Transition Fund. This fund provides support to territories facing serious socio-economic challenges arising from the transition towards climate neutrality.

\section{The Regional Development Fund (Fondo Nacional de Desarrollo Regional, FNDR), Chile}

The FNDR was created in 1974 to fund regional development and infrastructure projects, with the objective to achieve balanced territorial development. The Fund supports several programmes, such as the Regional Fund for Local Initiative, which funds community infrastructure projects that improve the quality of life of the poorest population of the commune. It takes into account the component of citizen participation through the municipalities, who represent the demands and needs in their territories Source: European Union (European Commission, n.d.[62]). (European Commission, 2021[63]); Chile (Metropolitan Regional Government of Santiago, n.d.[64]). 


\section{Identifying tax revenue opportunities}

\section{Innovations relating to taxes include new forms of taxes or new applications of taxes to support infrastructure investment. Examples include the use of environmental taxes and taxes allocated to transport projects.}

On average, shared and own-source taxes represent 39\% of total subnational government revenue in G20 countries, and $33 \%$ at a global level (OECD and UCLG, 2019 ${ }_{[12]}$ ). Typical own-source taxes, on which subnational governments have some taxing power over rates and/or bases, include property taxes, local business taxes, sales taxes, vehicle taxes and some environmental taxes. In some countries, subnational governments may also receive a share of national taxes, such as value added taxes (VAT), personal income taxes (PIT) and corporate taxes (CIT). An overview of some of the taxes that may be available to subnational governments is shown in Figure 3.2.

\section{Figure 3.2. Examples of taxes that may be available to subnational governments}

\begin{tabular}{|c|c|}
\hline & Personal income taxes (PIT); local income taxes; resident taxes \\
\hline \multirow{8}{*}{$\begin{array}{l}\text { Taxes that may be } \\
\text { avallable to } \\
\text { subnational } \\
\text { governments } \\
\text { (may be shared or } \\
\text { autonomous / own-source) }\end{array}$} & $\begin{array}{l}\text { Corporate income taxes }(\mathrm{CIT}) \text {; local business tax }{ }^{*} \text {; regional or local taxes on } \\
\text { economic activities }\end{array}$ \\
\hline & Value added taxes (VAT); sales tax; local consumption taxes \\
\hline & Property taxes*; Taxes linked to real estate activity \\
\hline & $\begin{array}{l}\text { Transport and vehicle taxes (e.g. car sales/registration; annual vehicle } \\
\text { circulation taxes) }\end{array}$ \\
\hline & $\begin{array}{l}\text { Energy taxes, including carbon taxes, taxes on energy products, motor fuel } \\
\text { tax, electricity tax, etc. }\end{array}$ \\
\hline & $\begin{array}{l}\text { Pollution taxes, including waste taxes, and taxes on the use of pesticides } \\
\text { and/or fertilisers }\end{array}$ \\
\hline & $\begin{array}{l}\text { Taxes on water and resources extraction, including tax proceeds from } \\
\text { commodity sectors. }\end{array}$ \\
\hline & Taxes on leisure, tourism, advertising, gambling, etc. \\
\hline
\end{tabular}

Note: * Can also represents a land value capture mechanism. Sources: See OECD $\left(2020_{[65]}\right)$ for a broader classification of taxes.

Property tax, in particular, is a cornerstone of local taxation in many countries in the world and has a strong link to the provision of local infrastructure due to the link between housing value and local infrastructure provision. Among G20 countries, recurrent property taxes account for $1.3 \%$ of GDP, $27.5 \%$ of subnational tax revenue and $8.9 \%$ of subnational revenue (OECD/UCLG, $\left.2019_{[14]}\right)^{2}$. While property taxes have a lot of merits (stable tax bases, solid return on tax collection, lack of vertical tax competition, a link to infrastructure provision, etc.), the proportion of property taxes within subnational tax revenue still varies considerably across countries. One of the main constraints that almost all countries encounter is the difficulty of calculating the value of tax bases. Beyond this, in many countries, the lack of an efficient and reliable cadastre and land registry, and procedures to resolve land disputes, are a common obstacle (OECD/UCLG, 2019[14]). In some countries, overcoming these constraints and implementing property taxes can provide an important way to support infrastructure investment.

\footnotetext{
${ }^{2}$ Data for 16 countries and European Union average. Data for Indonesia, Saudi Arabia and South Africa are not available. All the averages are unweighted.
} 
Outside of grants and subsidies, tax revenue usually contributes the greatest amount to subnational government funding, and many regions and cities rely on taxes to help fund infrastructure investment. Therefore, taxation can be one of the most straightforward way to raise funding for additional investment; however, it requires substantial political and popular support, and consideration of equity. While broadbased taxes may be appropriate to fund essential public infrastructure, such as public schools and local roads, they may be less appropriate for localised infrastructure where only part of the community benefits.

Tax revenues are often integrated into overall tax and fiscal frameworks, and not targeted at funding specific interventions or infrastructure. There are few countries that define - or permit - placing constraints on the use of tax revenues, such as the earmarking of tax revenues to support transport investments. In any case, well-targeted taxes may provide equity for infrastructure investment by providing a visible link between the cost for the provision for infrastructure and the beneficiaries who pay for the infrastructure. Given that subnational government infrastructure investment is local, taxes implemented at this level may automatically provide such a visible link. This might increase public acceptance of taxation to pay for local infrastructure. Examples of taxes to support infrastructure investment include the Atlanta Beltline line Tax Allocation District in the United States, the Versement Mobilité in France (Box 3.7) and local tourist taxes in various countries, which are increasingly being used to fund tourism infrastructure.

\section{Box 3.7. Taxes introduced to support infrastructure investment in the United States and France}

\section{Atlanta BeltLine Tax Allocation District (United States)}

The BeltLine Redevelopment Plan was developed to support urban development in Atlanta through investments in public transport, green spaces, affordable housing and public schools. As part of this plan, Invest Atlanta created a "taxation allocation district" (a defined boundary for higher taxes to be raised) and used tax increment financing to help finance the project, with a plan to raise USD 1.5 billion of funding, $33 \%$ of the total project cost. Remaining funding was to be from federal government and local sources, such as parking taxes and donations. As a consequence of the 2008 recession, and a lawsuit, income from the tax allocation district has been halved from the initial forecast.

\section{The Versement Mobilité in France}

The "mobility contribution", first created in 1974 and updated in 2021, is a payroll tax levied on private and public employers. It is paid by employers with at least eleven employees. It can be levied by local authorities or inter-municipal cooperation bodies and the proceeds are primarily devoted to the financing of public transport (investment and operations). The contribution is calculated as a percentage rate of payroll, which set by the local authorities, with the rate capped by law. Larger regions can levy higher rates. The rate cap also depends on whether a 'grade-separated' public transport project is planned or under construction. Since its introduction in the 1970s, this tax has significantly contributed to the modernisation of urban transport networks. In 2020, it financed nearly $60 \%$ of the public transport budget of Île-de-France Mobilités, which redistributes the revenues to RATP (metro), SNCF (railways) and private bus companies in the Ile-de-France region.

\section{Tourism taxes}

Over the last 10 to 15 years, there has been an increase in the number and scope of tourism-related taxes, fees and charges. In 2017, tourism taxes were levied by more than two-thirds of EU Member States, approximately half of the states in the United States, and in Canada, Mexico and Switzerland. The use of tourist tax revenues varies from one country to another, or even from one city to another, but they are often dedicated to support tourism infrastructure and amenities, historical and cultural preservation and restoration, and to improve urban infrastructure, including public transportation.

Source: United States (Merriman, 2018[66]; US DOT, 2019[67]); Tourism taxes (OECD, Forthcoming[68]). 
Environmental taxes (including carbon-pricing instruments) also provide an opportunity to increase revenue to support investment. Environmental taxes or levies are placed on activities that create negative environmental externalities, with the aim of factoring environmental damage into prices to help steer production and consumption choices to environmentally-friendly options. Examples include taxation on transport (cars sales, registration taxes, and annual vehicle circulation), pollution (carbon taxes, waste taxes and taxes on the use of pesticides and/or fertilisers), water abstraction and resources extraction. In some cases, revenue may be earmarked or allocated for environmental purposes, such as recycling infrastructure, waste water or the preservation of natural environments. In Catalonia, Spain, landfill and incineration taxes are partly allocated to invest in waste infrastructure (Box 3.8). In Yokohama City, Japan, a green tax supports the protection and expansion of public green spaces (Box 3.8).

In some cases, environmental taxes and carbon pricing instruments can create equity challenges that need to be offset in instrument design. For instance, the use of carbon pricing such as an Emissions Trading System (ETS) can have a higher impact on poorer households as it can raise energy and product prices. To account for this when establishing environmental taxes and ETS measures, policy makers can establish redistribution and compensation mechanisms to assess, ex-ante, these negative effects on lower-income groups. This occurred in California when implementing the cap-and-trade system (Box 3.8).

\section{Box 3.8. Environmental taxes and emissions trading schemes in Spain, Japan and the United States}

\section{Landfill and incineration taxes in Catalonia, Spain}

Catalonia introduced a landfill tax and an incineration tax in 2004 and 2008, respectively. The policy objectives of the taxes were to discourage landfilling and incineration of municipal solid waste and encourage separate collection and recovery of waste streams. An additional objective was to generate revenues for the Catalan Waste Management Fund, the most important instrument for financing waste management infrastructure. These taxes also provided additional revenue for municipalities, helping them modernise and develop their waste collection and recycling systems.

\section{Yokohama Green Tax, Japan}

Yokohama City is the second largest city in Japan, with a population of 3.7 million. The city has faced rapid urbanisation and population increases, resulting in a decrease in the city's green coverage from $50 \%$ in 1970 , to $29.8 \%$ in 2009 . To help combat this decline, the city implemented the Yokohama Green Up Plan to promote, create and nurture green spaces. As part of the plan, citizens have paid a green tax since 2009. The taxation rate of JPY 900 per year for individuals and a variable rate for corporations depending on size, is added to the municipal tax rate. In 2020, this tax provided approximately JPY 2.9 billion in revenue for the city government, which is then allocated to purchase private forest land, forest maintenance programmes and promoting volunteering, among other areas.

\section{The California Cap and Trade system, United States}

Established in 2012, the California's carbon cap-and-trade programme is one of the largest multi-sectoral emissions trading systems in the world. It is also the main source of funding for California's climate investments, allocating revenues deposited into the state's Greenhouse Gas Reduction Fund to a range of low-carbon and climate-responsive projects to reduce GHG emissions, such as public transport and renewal energy infrastructure, with an emphasis on disadvantaged communities. At least $35 \%$ of investments must be made in disadvantaged and low-income communities. USD 14.24 billion have been collected since beginning of programme, including USD 1.7 billion in 2020.

Sources: Yokohama (Takagi, 2014[69]; City of Yokohama, 2021[70]); Spain (Agència de Residus de Catalunya); California (ICAP, 2021 [71]) 


\title{
Adopting user charges and fees, while maintaining infrastructure accessibility
}

\author{
Innovations relating to user charges and fees can strengthen the link between the beneficiaries of \\ infrastructure and the payment for that infrastructure. Examples highlight the use of road user charges, \\ congestion charges and waste charges.
}

On average, among G20 countries and at a global level, user fees and charges represent around $9 \%$ of total subnational government revenue (OECD and UCLG, 2019 [12]). Typical user charges and fees collected by subnational governments include administrative service fees, transport fares, parking fees, urban congestion charges, motorway tolls, utility fees, and fine penalties and forfeits (see Figure 3.3). User charges and fees are levied on the users of services provided by local entities (e.g. water, electricity, garbage collection, transport, etc.) to cover the costs of service and infrastructure provision. The "Pay As You Throw" System in Seoul, Korea, for example, is a volume charge for the disposal of waste (Box 3.9).

User charges and fees can provide an equitable way of funding infrastructure if the accessibility of lowincome users is considered. Charges and fees provide a direct link between beneficiaries and payment, and for many types of infrastructure it is considered appropriate for users pay for infrastructure costs. Examples of user charges and fees include tickets at sporting facilities and cultural infrastructure (municipal theatres, concert venues, etc.) and public transport fares. At the same time, user fees and charges can reduce accessibility, particularly for lower socio-economic groups. To maintain accessibility, subnational governments often implement tiered user charges and fees, such as concession rates.

Figure 3.3. Examples of user charges and fees that may be leveraged by subnational governments

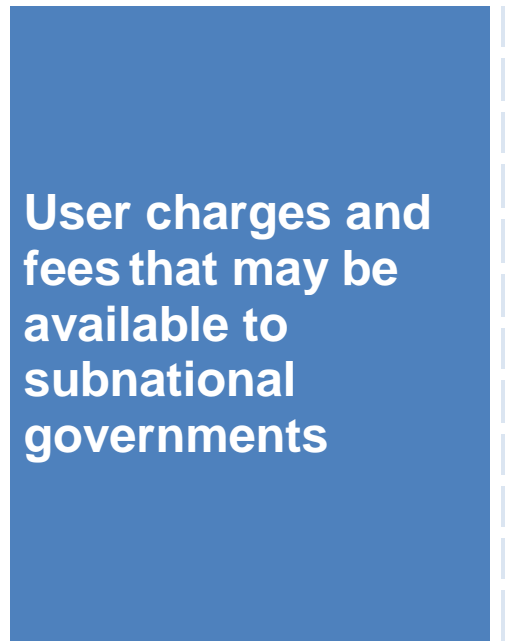

Administrative service fees
Fines, penalties and forfeits
Development fee or impact charge*
Motorway tolls
Congestion charges
Transport fares
Parking fees
Environmental fees
Admission fees (to museums and parks, for example)
Tuition fees
Vehicle licence and registration fees
Water, sewerage and electricity chargers

Note: * Can also represents a land value capture mechanism. Sources: See (OECD, 2020[65]) for the OECD classification of taxes.

User charges and fees can also help achieve climate or other policy objectives by providing a signal for users to regulate demand. For example, this can allow for an infrastructure funding strategy based on charging for activities deemed negative for the climate and can also support the optimisation of asset use by reducing demand for infrastructure at peak times. Climate-friendly user fees and charges include congestion charges, parking fees, tolls, water and wastewater user fees, urban tolls, or utility fees (water, waste and energy) (Merk et al., 2012[72]). In London, Milan, Singapore and Stockholm, for example, congestion charges have resulted in reduced carbon emissions, and in Milan, the congestion charge has also been linked to a drop in the level of pollution emitted from vehicles (OECD, 2019 [15]) $($ Box 3.9).

User charges and fees can also be an effective funding mechanism to cover the investment needs for maintenance and upgrade. In Scotland, water and waste charges are reviewed on a regular basis in a 
process called the Strategic Review of Charges, which ensures that the operator is adequately funded to make capital investments. Through these charges, the Scottish Water has been able to use tariff setting processes to fund capital investments from revenues and decrease debt levels (OECD, 2021 [8]).

One particular type of user charge that may become more used is distance-based road user charges. As electric vehicles become increasingly common, and fossil-fuel vehicles are phased out or become more fuel efficient, existing fossil fuel taxes will decrease, posing a revenue challenge for many governments. In the Republic of Slovenia, for example, fuel taxes represent $14.6 \%$ of total central government tax revenue (OECD and ITF, 2019[73]). Distance based road user charges provide an opportunity for national or subnational governments to secure stable revenue streams linked to road infrastructure use, and create the ability to price-in other negative externalities related to passenger-vehicle use such as congestion. In 2021, the Victorian State Government in Australia introduced a new distance-based road charge for zero and low emissions vehicles (Box 3.9).

\section{Box 3.9. User charges and fees in Korea, Italy and Australia}

\section{The "Pay As You Throw" System in Seoul, Korea}

Seoul (Korea) has developed and continuously improved a pay-as-you-throw system since the 1990s. General waste is charged on a volume-based fee system for households, businesses and office buildings instead of a disposal bill based on building areas or property taxes. Waste volume is measured through designated and district-specific biodegradable bags, available in local shops and which come in sizes ranging from two to 100 litres. Food waste can be discharged in various ways. People can use standard waste bags sold by local authorities, standard plastic containers equipped with an electronic chip or sticker (that contain user's name and address), and weight-based payment using an electronic card with radio frequency identification. There are several limitations however attached to the development of user charges and fees, including the legal ability of subnational governments to create and determine the level of such fees particularly in areas considered as essential (e.g. energy sector), as well as the capacity and willingness to pay of users and capacity management.

\section{Area $\mathrm{C}$ Milano congestion charge, Italy}

In 2012, the congestion charge was introduced in a zone in the central area of Milan, Italy, with restricted vehicle access (named "Area C"). The programme seeks to reduce traffic, promote traffic and reduce the level of air pollution. All revenues from the system are used to promote public and sustainable transport. An assessment in 2015, identified that Area $C$ resulted in a $28 \%$ decrease in road congestion, a $24 \%$ reduction in road casualties (data from 2011 to 2012), reduction in pollutants (PM10, Ammonia, Nitrogen Oxides, Carbon Dioxide) of between $10 \%$ and $42 \%$ and a reported $10 \%$ increase in the productivity of freight deliveries in the city centre.

\section{Road-user charge for zero and low emissions vehicles, Victoria, Australia}

In 2021, the Victorian State Government introduced distance-based road charge of AUD $2.5 \mathrm{cent} / \mathrm{km}$ for electric and other low emissions vehicles, including hydrogen vehicles. The charge is levied through an odometer reading during existing vehicle registration and renewal processes. The charge seeks to ensure that owners of electric and low emissions vehicles continue to pay a contribution to the cost of building and maintaining the road network. The Government of South Australia has also commenced consultation for a new Electric Vehicle Road-User Charge. In Australia, existing fuel taxes are levied at the national level, while road-user charges are being introduced at a subnational level.

Source: Seoul (OECD, 2019[15]; Seoul Solution, 2018[74]); Milan (European Commission, 2013[75]; C40 Cities, 2015[76]); Victoria (Government of South Australia, 2021 [77]; Premier of Victoria, 2021 [78]; VicRoads, 2021 [79] 


\section{Capturing increases in land value}

Land value capture can help to capture windfall gains arising from infrastructure investments or land use changes in a geographic area. Examples include the use of developer obligations and transferable development rights.

Infrastructure investment and land use changes can result in land value increases, creating a windfall gain for nearby property owners. Land value capture instruments seek to 'capture' some of these gains to provide local authorities with additional revenue. Land value capture instruments include a mix of instruments, including taxes and user charges and fees, characterised by their intention to capture windfall gains arising from government intervention (Box 3.10). These types of instruments can be applied to all sizes of cities - small, medium and large - and in all countries if certain framework conditions are established. They have a particularly strong potential in developing countries faced with rapid population growth and high infrastructure needs (World Bank, n.d.[80]).

\section{Box 3.10. Overview of land value capture mechanisms}

Land value capture includes a diverse range of mechanisms and policies, which consist of taxes, user charges and fees, and other forms of revenue. Some selected land value mechanisms include:

- Developer obligations: A charge to developers (either in-cash or in-kind, where the developer directly funds complimentary infrastructure) linked to obtaining approval to develop or build on a land parcel. The contribution is designed to compensate for the impact of new development on existing infrastructure, or help pay for the cost of additional infrastructure and service provision due to new developments. There are various names for developer obligations across countries including development charges, impact charges, linkage fees, frontage charges and density charges. Developer contributions can be channelled into a dedicated local development fund.

- Infrastructure levies (also known as betterment levies or special assessments): A tax or a fee on land charged to landowners, where that land has already gained in value because of public infrastructure investments, also known as a special assessment in the United States. Infrastructure levies are frequently used to finance the construction and upgrade of sidewalks, streets, water mains, storm sewers and sewers. Levies are either one-off or may be spread over several years.

- Charges for development rights: Developers pay cash or in-kind for additional development rights above a defined land-use, density and/or height baseline, but within the maximum density permitted by the zoning plan. Developers building beyond the baseline or converting land to a higher use contribute as required by the corresponding legislation. In some jurisdictions, developers can bid to purchase development rights in the form of higher floor area ratio certificates at an auction. Moreover, developers can sometimes transfer the density potential of one parcel of land to a noncontiguous parcel that is better suited for greater densities (transferable development rights).

- Tax increment financing: This mechanism assigns future increases in property taxes relating to a nearby infrastructure investment to help pay for that investment. Tax increment financing earmarks a portion of future tax increases in a designated area. Tax increment financing does not capture any additional value beyond increases in property tax that would have occurred anyway, so may sometimes not be strictly considered a value capture mechanisms. It is an instrument that can help subnational governments access finance, where proceeds are repaid from the tax increment.

- Affordable housing requirements: Some municipalities require developers of residential properties to set aside a fixed percentage of units that are affordably priced for purchase by those with low or moderate income. 
- Land readjustment: Land parcels are pooled and readjusted into different shapes and sizes in an orderly configuration, to make space for public improvements such as transit lines, roads, parks or public utilities. The infrastructure investments undertaken on the pooled land increase the value of the properties in the redeveloped area. Each landowner then receives a smaller parcel of land that has higher value than the original parcel due to the improvements made.

- Direct development (Integrated rail and property development): A public authority jointly develops new transit infrastructure and housing, with the proceeds from the development being used to pay for the new transit infrastructure.

- Privately-owned public spaces: Urban spaces that result from a negotiated trade-off between local governments, private landowners and developers. Developers are allowed to build outside planning limits, would receive a tax-cut or are exempt from other regulations, in return for providing a publicly usable space. Multiple examples exist in Japan, the United States and Australia.

To support governments at all levels to better exploit land value capture mechanisms, the OECD and the Lincoln Institute of Land Policy are preparing a Global Compendium on Land Value Capture tools used around the world (OECD, 2021[81]). The World Bank has developed an online interactive tool to help regional and local governments decide which land capture instrument to adopt for a specific project: Urban Regeneration Decision Tool, https://urban-regeneration.worldbank.org/survey.

Sources: (Lincoln Institute of Land Policy, 2018[82]; UCLG, 2016[83]; Kim, 2016[84]; University of Tokyo, 2013[85]; World Bank Group, 2015[86]) (University of Tokyo, 2013[85])

Land value capture mechanisms are often complex and can face a number of obstacles. These include the lack of adequate legal frameworks on land use, the failure to consistently apply regulations (when they do exist), the absence or dysfunction of land markets, insecure property rights, potentially high initial costs and implementation problems, among other areas (World Bank, n.d.[80]; Inter-American Development Bank, 2017[87]). One key technical difficulty across instruments is quantifying incremental value generated by public interventions. Subnational governments may struggle to strike the right balance between capturing fair values and providing incentives for private sector market participation. Land value capture may also create tensions between central and local government as to how revenues are spent (Minstry of Housing, Communities and Local Government, UK, 2018[88]).

When deciding which value capture instrument is most suitable, subnational governments needs to take into account the type of project (whether it is a rehabilitation of deteriorated areas or greenfield development), the scope of the value capture (whether it is recovery of just project cost or the full land value increment), time of collection (ex-ante and ex-post), and the degree of sophistication the instrument required, among other areas (Inter-American Development Bank, 2017[87]). For transportation projects in particular, there is often a strong link between infrastructure investment and property value increases. For these projects, identification of value capture opportunities can be supported by integrated land use and transport planning. In some cases, authorities responsible for transport development may be established with joint responsibility for transport and land development, as is the case with MTR in Hong Kong (China) and the Copenhagen City and Port Development (Denmark).

Many different land value capture instruments exist, which provide various innovations that can be harnessed by subnational governments. Three are examined in more detail in this section-transferable development rights, development charges and tax increment financing.

\section{Transferable development rights}

The principle of Transferable Development Right (TDR) is to unbundle the development potential of a given property from the land, and make the development rights a separate commodity, which a property owner can choose to sell at a negotiable price. In some cases, this is used to allow public authorities to obtain 
space to provide facilities or infrastructure by compensating an owner without a monetary payment. In general, a property owner can obtain TDRs from a local public authority in the form of certificates, which the owner can subsequently use for a property development or trade. TDRs, in particular 'air rights', have been used extensively in New York for over 50 years to support planning and urban design goals (NYC Planning, 2015[89]).

This instrument is particularly relevant for growing cities with a scarcity of land and it has been used to generate additional infrastructure funding while increasing urban density. It can be used for incentivising the conservation of heritage landmarks and expansive touristic lakes, or offered to support slum redevelopment and affordable housing projects (Hans, 2020[90]). TDRs have been adopted in India and Brazil (Box 3.11).

\section{Box 3.11. Transferable development rights in Brazil and India}

\section{Certificates of Additional Construction Potential, Brazil}

Certificate of Additional Construction Potential (CEPAC) is a municipal instrument that aims to use funding from developers to compensate for the cost of new infrastructure. Municipal governments create certificates with development rights for densification and rezoning in defined areas, which are sold to developers to raise funding for new infrastructure. Developers bid at auctions to purchase building rights certificates in the form of higher 'Floor Area Ratio' from the city. The City of São Paolo has generated nearly USD 2 billion from CEPACs to fund infrastructure and planning programmes within a designated redevelopment area (Sandroni, 2010[91]; OECD, 2021 [10]]).

\section{Transfer of Development Rights In Indian Cities}

In 2017, the Ministry of Housing and Urban Affairs of India established a Value Capture Finance Policy Framework in which TDRs can be adopted at a state and Urban Local Body (i.e. municipality in urban areas) level. The policy instrument provides flexibility to subnational authorities to compensate landowners by issuing Development Right Certificates when acquiring land for infrastructure projects, which can then be used at present market value without incurring any actual outflow of money. This method is being used in Mumbai, Hyderabad, Ahmedabad, and other major cities in India. One challenge with the use of TDRs in this context is apprehension from landowners due to fluctuations in the property market and the difficulty of finding a buyer (Hans, 2020[90]; Financial Express, 2020[92]).

\section{Developer obligations}

Developer obligations (also known as development charges, impact charges or local infrastructure tariffs in some countries) are imposed in relation to land development and redevelopment projects. These charges are typically paid by developers in cash or in-kind to help cover the capital costs of new public infrastructure required to serve a development or to compensate for the impact of a new development on existing infrastructure. Infrastructure supported through developer obligations can include roads, sidewalks, recreational facilities, libraries, parks, fire stations, schools, water, electricity and many other types of other infrastructure (Haas and Kriticos, 2019 ${ }_{[93]}$ ). Development charges are common in many countries. Examples include building permission charges in Hyderabad in India, developer charges as part of the northern line extension in United Kingdom (UK), education department charges in Canada, and developer obligations in Germany (Box 3.12). 


\section{Box 3.12. Development impact charges in India, United Kingdom, Canada and Germany}

\section{Land Value Capture along the Outer Ring Road in Hyderabad in India}

Hyderabad uses "special development charges" for building permissions along a new transit corridor, which are up to 1.5 times the normal fee. This is coupled with "development deferment charges" that are levied on landowners who keep lots vacant to discourage them from holding onto land for financial speculation (Mahendra et al., 2020[94]).

\section{The Northern Line Extension, United Kingdom}

The UK is using developer charges to support the extension of the Northern Line on the London Underground. Developer contributions were expected to provide a total contribution of GBP 266 million, with GBP 200 million being provided from the redevelopment of the Battersea Power Station. The developer contributions are collected through the Wandsworth and Lambeth local councils. The project is also supported by an enterprise zone where the business rates in the zone are retained and invested locally for a period of 25 years (Transport for London, 2013[95]).

\section{Education development charges, Canada}

Education Development Charges (EDCs) provide school boards a way to collect funds from growthrelated developments to purchase land for new schools. In order to qualify for EDCs, a school board must show that the number of students that it needs to accommodate is larger than the space available on a district-wide basis. Charges imposed by the Toronto Catholic District School Board, for example, have been used to fund the acquisition of school sites and related costs. Funds cannot be used to support the cost of building new schools or renovating existing ones, only to prepare land. Some school boards have asked to expand the definition of "education land costs" to include construction costs for new buildings and other costs to meet growth-related infrastructure needs such as additions and renovations to existing schools (City of Toronto, 2021[96]; Toronto District School Board, n.d.[97]).

\section{Developer obligations for public urban infrastructure provision in Germany}

The development proposals and linkage plans provides a way to gain approval for a development proposal that would not be otherwise permitted. This is achieved by including it in a special kind of development plan under the condition that additional infrastructure is provided by the developer. In the development proposal and linkage plan that is developed, the developer commits to pay for related planning costs and complete a development with all the relevant urban infrastructure (Hansson, 2017[98]).

\section{Tax increment financing}

Tax increment financing (TIF) enables local governments to use the expected income from property taxation in a designated area to finance investment in infrastructure. This instrument is most commonly used to support urban public transportation systems by allocating future revenues from property tax increases towards the repayment of financing used to cover up front costs. Given that tax increment financing does not capture any new revenues that would have otherwise been collected by a property tax, it is often not strictly considered a land value capture instrument.

TIF implementation starts with the local government establishing a "TIF District"- a geographic area whose purpose is to capture a portion of the increase in the property tax value resulting from new infrastructure investments. In this district, the local government uses the property value (tax base) on a specific date as a baseline. This value is "frozen" for a long period of time, ranging from 10 to 35 years. As investments begin to take place within this district, property values increase. The new property tax minus 
the tax on the frozen property values (tax increment) is collected by the TIF authority into a specific fund committed to the repayment of TIF debt obligations (e.g. a TIF bond) or for reinvestment in public infrastructure for further development. In some cases, TIFs are used to payback private development expenses payed upfront, such as site preparation and construction (World Bank Group, n.d.[99]; InterAmerican Development Bank, 2017[87]). An example of tax increment financing is The Innovation District of Medellin, Colombia (Box 3.13)

\section{Box 3.13. Land value capture mechanisms in Colombia}

\section{The use of tax increment financing for an innovation district in Medellin}

The city of Medellin is surrounded by mountains and thus geographically constrained and faces a shortage of urban land. The Innovation District of Medellin pilot project aims to convert a low-density, low value added commercial downtown district into a mixed-use real estate development. To support this project, the city of Medellin defined a TIF for a 16-year term from 2021 to 2035 to raise financing. This was supported by an assessments of the real estate market, base-level of property taxes, the tax increment potential, financing opportunities and project feasibility.

An analysis of the subnational and national legal and regulatory frameworks, undertaken with support of the World Bank, identified that Colombian legislation already provided basic elements and a wide array of urban development instruments that enable cities to use TIF for urban infrastructure. Main cities in Colombia have a steadily growing real estate market, and The cadastral system in Colombia is sufficiently advanced to enable its main cities to accrue future revenues.

\section{A longer history of land value capture in Colombia}

This initiative complements the long standing experience of several Colombian cities as leaders in land-based financing instruments. Inspired by the Constitution, which stipulates that one of the state's duties is to capture the added value generated by public actions, Colombia created two revenue-raising mechanisms aimed at financing urban development by capturing the capital gains from property and land generated by public infrastructure projects. The Contribución de valorización (1921) is an infrastructure levy. The Participación en Plusvalías (1997) aims at recovering part of the increase in land value resulting from a change in land-use regulations. These instruments are primarily used by large cities, such as Bogotá, Barranquilla, Bucaramanga and Cali.

Source: (Velasco Bernal and Almonacid, 2021 [100]; Luis Acero and Nunez, 2014[101])

\section{Leveraging income from existing assets}

Innovations relating to existing assets that seek to increase the long-term revenue generated from the existing assets owned by subnational governments. Examples include the use of asset leasing and Asset Recycling, where the proceeds from asset sales are used to support new investments.

Globally, the book value of commercial assets owned by all levels of government has been estimated to be USD 75 trillion (Detter and Fölster, 2015[102]). While international data on subnational government assets is limited, the asset holdings of some subnational governments can be substantial. The City of Boston in the United States, for example, has been estimated to have real estate holdings of USD 55 billion (Dag Detter and Stefan Fölster, $\left.2018_{[103]}\right)$. In Amsterdam, the municipal government owns $80 \%$ of land and leases the land in return for a ground rent (canon) (OECD, 2017[104]).

Meanwhile, revenue from subnational government assets ('property') typically represents a small proportion of total subnational government income. On average, income from assets ('property income') 
accounts approximately $2 \%$ of total subnational government revenues among G20 countries and globally $\left(2019_{[12]}\right)$, but this amount can be larger in certain jurisdictions. In the People's Republic of China (hereinafter "China"), for example, municipal government revenue from land leasing has been a rising since 2004, with an average annual proportion of revenues from this source now totalling more than $30 \%$ of total revenues (Zhang et al., $2020_{[105]}$ ). Land assets are one of the local governments' main tools to obtain revenue and leverage for financing infrastructure construction.

Assets owned by subnational governments include 'financial and non-produced assets', such as local public companies and mineral resources, and 'produced assets', such as infrastructure or equipment (Figure 3.4). These assets may provide ongoing revenue from continued ownership or one-off revenue from sale. Types of ongoing income from these assets include dividends, interests, rents, and royalties from subsoil assets.

\section{Figure 3.4. Examples of potential subnational government assets}

\begin{tabular}{|c|c|c|}
\hline \multirow{8}{*}{$\begin{array}{l}\text { Subnational } \\
\text { government } \\
\text { assets }\end{array}$} & \multirow{5}{*}{$\begin{array}{l}\text { Financial and } \\
\text { non-produced } \\
\text { assets }\end{array}$} & $\begin{array}{l}\text { Income from subnational state-owned enterprises } \\
\text { (i.e. local public companies) }\end{array}$ \\
\hline & & $\begin{array}{l}\text { Financial assets } \\
\text { (i.e. loans, deposits or investments providing interest) }\end{array}$ \\
\hline & & $\begin{array}{l}\text { Subsoil and resource assets } \\
\text { (i.e. land, timber, mineral resources). }\end{array}$ \\
\hline & & Land holdings \\
\hline & & Intellectual property \\
\hline & \multirow{3}{*}{$\begin{array}{l}\text { Produced } \\
\text { assets }\end{array}$} & Buildings \\
\hline & & Equipment \\
\hline & & Other built assets, including infrastructure \\
\hline
\end{tabular}

Sources: See (OECD, 2020[65]) for the OECD classification of property income, which relates to government assets.

The sale (divesting or privatising) of subnational government assets, or long term leasing (including Public Private Partnership concessions), should only be done after undertaking appropriate public interest checks (OECD, 2018[106]). Among other areas, this can include ensuring that the rationale for government intervention is no longer present and the assets will not exist in the future, that there are appropriate regulatory frameworks in place to maintain public access, that it will improve economic efficiency, that sales or leases will provide value for money, and that funding will be used efficiently (OECD, 2018[106]; OECD, 2019[107]). These checks may help ensure that lower government control does not substantially lower public value, for example on access rights, pricing and future infrastructure modifications.

Developing a comprehensive, clear and updated inventory of local assets is an important first step. Such asset inventories are lacking in many G20, OECD and other countries, but they are critical for improved asset management, fiscal management and for leveraging assets to support investment. Physical asset and land registers can allow an assessment of the potential for making better use of these financial and non-financial assets and increasing revenues they may generate (i.e. from taxes, fees, rents, dividends, land value capture instruments, sales, etc.).

One particular risk that can be faced during privatisation is that an objective to maximise short-term proceeds can conflict with the objective to establish long-term regulations and competition frameworks for these assets in the future. If not done carefully, this may risk a reduction in overall economic efficiency 
(ACCC, 2021 $\left.{ }_{[108]}\right)$. For example, divesting or leasing an asset could result in unanticipated, or economically inefficient increases in fees or charges on users, which has equity and accessibility implications.

Two particular approaches to leveraging assets that have been used to directly support infrastructure investment are asset recycling and municipal land sales.

\section{Asset recycling: Divesting public assets to support new infrastructure investment}

'Asset recycling' involves divesting or privatising existing assets with an explicit purpose of funding new infrastructure investment. This approach does not necessarily create any additional funding for infrastructure, as potential future public income from assets is forgone when assets are sold. This means that any funding released from asset privatisation should be used to support economically productive investments, which provides a higher level of economic, social and environmental well-being than would have been achieved by continued ownership of the existing assets. A prominent example of asset recycling is the Asset Recycling Initiative in Australia (Box 3.14).

\section{Box 3.14. The Asset Recycling Initiative in Australia}

Between 2014 and 2019, the Australian Federal Government implemented the Asset Recycling Initiative to support State and Territory governments to divest assets and use the proceeds to fund additional infrastructure that supported economic growth and enhanced productivity.

The National Partnership Agreement on Asset Recycling, agreed by the Council of Australian Governments in 2014, included an asset recycling initiative and associated fund. Where an asset was divested by a State government, the federal government provided an additional financial contribution worth $15 \%$ of the assessed sale value of the asset.

A review of the programme found that it was influential in bringing forward assets for divestments and that commonwealth funding played a role garnering additional community support for divestments. The programme supported AUD 15 billion in additional economic infrastructure, with commonwealth funding of AUD 2.3 billion.

Source: (Parliament of Australia, 2014[109]), (Australian Government, 2019[110]).

\section{Land sales or long-term leases to support new infrastructure investment}

In many countries, subnational governments own and manage substantial land holdings. These holdings can include undeveloped land, former industrial land, government buildings and land owned by transport network companies. For many municipal governments, land can be a valuable but limited and nonrenewable asset, meaning that it needs to be carefully managed over time. When there is a clear policy objective and no public reason for continued ownership, land ownings might be sold or leased to support infrastructure investment. A critical part of undertaking land sales is developing a comprehensive, clear and updated inventory of local land assets. In India, a government land inventory and valuation process was undertaken in order to support future infrastructure and urban development planning (Box 3.15). Land sales and leases have also be used in many countries to help fund infrastructure investments and the ongoing management of infrastructure, including by public organisations that own and manage land assets(i.e. Network Rail in the United Kingdom). 


\section{Box 3.15. Land valuation in India}

\section{Ahmedabad land inventory and valuation, India}

Public land assets were systematically inventoried and their value estimated using geographic information system (GIS) data and land records. This land information was then used to analyse and build scenarios for policy decisions and land management. The study showed that Ahmedabad possessed a large amount of public land, amounting to $32 \%$ of the buildable space in the city. The study found that financial resources that could be generated by monetising public land ranged from INR 20 , 000 crores and 54000 crores (about USD 3.6 billion and USD 9.8 billion).

Source: (World Bank, 2013[111])

\section{Opportunities for innovation in infrastructure financing}

In G20 countries, subnational government debt represents approximately $20 \%$ of total government debt (OECD and UCLG, 2019 ${ }_{[12]}$ ), which supports infrastructure investment. The use of financing has an important role to spread the typical high up-front costs of infrastructure over time. This can enable subnational governments to undertake larger investments than they would have otherwise been able to if they relied on their balance sheet. The use of financing instruments should be considered on a case-by-case basis, and should be supported by transparent and sound fiscal frameworks to manage the longer-term implications of debt and ensure fiscal stability and budget sustainability.

This section highlights five areas where financing innovations can occur: credit enhancement programs, loans, bonds, equity and the type of finance provider.

\section{Supporting access to finance through credit enhancement programmes}

\section{Credit enhancement programs can improve access to, and the terms of, subnational government borrowing. This includes the use of guarantees.}

Before providing finance through bonds or loans, investors assess the creditworthiness of subnational governments. This assessment determines if finance should be provided and interest rate that should be charged to cover the risk associated with financing of the particular subnational government, usually informed by a credit rating where available. Subnational governments with weaker financial positions and lower creditworthiness, may be not be able to access private finance or may have higher financing costs, which can reduce their ability to support infrastructure investment. Only $4 \%$ of the 500 largest cities in developing countries are considered creditworthy in international capital markets and only $20 \%$ can access local capital markets (World Bank, 2013[112]).

Credit enhancement programmes seek to increase the access, reduce the cost, and enhance the terms of finance for subnational governments. These programmes can reduce risk for investors, which can increases access to finance and lower the cost of borrowing. Credit enhancement programmes transfer risk from the investor to the provider of the credit enhancement (typically multi-lateral finance institutions, upper-level governments or other public finance institutions), which means that the credit enhancement provider has funds at risk if the subnational government or project defaults. To manage the risk, credit enhancement providers may undertake expert assessments as part of the guarantee process, which also provides a level of quality assurance. The European Investment Bank (EIB), for example, has a key role in credit enhancement in Europe by providing guarantees to support loans or bond issuances by 
subnational governments or project authorities, or by providing low-interest finance to projects (EIB, $2021_{[113])}$.

One of the common mechanisms for credit enhancement is a guarantee, which is provided to a finance provider with an offer to repay debt in case of a default or other pre-agreed risk. When using a PPP model, for example, guarantees can be provided to cover specific risks, such as revenue assumptions, the making availability payments, and responsibility for assuming debt obligations upon contract termination.

\section{Exploring new forms of loans and financial leases}

\section{Innovations relating to loans and financial leases seek to provide alternate forms finance to subnational governments, with the potential to lower financing cost, increase access or better match investments with investors. Examples include the use of low-interest loans and green loans.}

Loans are one of the main sources of external finance for many subnational governments and are often the only source of finance available at a local government level. Among G20 countries, loans represent $41 \%$ of subnational government debt, which is followed by commercial debt with suppliers (22\%) (OECD/UCLG, 2019[14]).

Infrastructure can be financed through general lending to subnational governments or through structured project finance. For many subnational governments, general lending is the primary way to access infrastructure finance and project finance is only available for large infrastructure projects. General lending is provided against subnational government revenues, based on an assessment of credit ratios to assess debt repayment capacity. Project financing 'ring fences' assets and removes any revenues and costs from the governments' financial accounts. In the case of default, project finance lenders may only be able to recover money from 'ring fenced' assets and not from other government assets or revenues (nonrecourse). Project finance is typically used in public-private partnerships (PPPs) through the establishment of a special purpose vehicle. The use of PPPs is explored in the section on investment approaches.

Three specific types of loans that can support infrastructure investments are public low-interest or subordinated loans, private project finance loans and green loans. For some types of infrastructure related assets, such as buses, an alternate financing mechanism is lease financing, which is also covered below.

\section{Access to low-interest and subordinated loans}

Low-interest and subordinated loans can be provided by multi-lateral finance institutions, upper-level governments or other public finance institutions to help finance infrastructure investments and reduce the overall cost of borrowing. Low-interest and subordinated loans may be provided as part of a broader credit enhancement programmes, as they can help increase subnational governments' access to other forms of private finance.

Low-interest loans may be provided to support financing on a specific project or to support general subnational government financing needs. They are provided with below-market interest rate (or no interest), and may also have more lenient financing terms. These loans can provide a cheaper cost of financing to subnational governments and may also improve their access to private finance by reducing the amount of private finance required in an investment. The United States, for example, provides lowinterest loans as part of the Transportation Infrastructure Finance and Innovation Act (TIFIA) lending programme to state governments (Box 3.16). In Bulgaria and Colombia, central governments established specific funds with a role to provide low-interest loans to support municipalities to gain access to lowercost finance (Box 3.16, and further examples of funds in the section on investors).

Loans can also be subordinated, which means that they are paid back last in the case of a default or bankruptcy (highest risk loan). Subordinated loans reduce the risk for other debt providers, which can 
encourage private sector investors to participate in a project, or it can lower the cost of debt for subnational governments.

\section{Box 3.16. Low-interest loans in Bulgaria, Colombia and the United States}

\section{Fund for Local Authorities and Governments in Bulgaria (FLAG)}

The Bulgarian government established the FLAG in 2007 to provide financial assistance to municipalities (and groups of municipalities) for the absorption of EU funds for municipal infrastructure and to support the required administrative capacity of municipalities for project development and implementation. FLAG is an independent legal entity that provides bridge financing in the form of lowinterest loans to municipalities, groups of municipalities and public entities owned or controlled by municipalities that are beneficiaries of EU funding. The loans provided by FLAG are repaid by municipal budgets as due debt. On 17 January 2020, a memorandum of understanding was officially signed between the EIB, the Fund of Funds, and FLAG, the purpose of which was to establish a Bulgarian Investment and Co-ordination Platform for Urban Development to support sustainable urban development projects in Bulgaria.

\section{FINDETER (Sociedad Financiera de Desarrollo Territorial S.A.) in Colombia}

FINDETER is a public development finance agency created in 1989 and owned by the Colombian government and departments to fund significant local and regional infrastructure projects. FINDETER acts as a second-tier lender, encouraging first-tier lenders (commercial banks) to enter into direct relationships with local governments by rediscounting loans that commercial banks make to local borrowers. Therefore, it makes lending to local entities more financially attractive for commercial banks and it allows longer maturities at attractive rates to be offered. FINDETER relies on international financing (Inter-American Development Bank, World Bank, Agence Française de Développement) and financial markets, receiving very high credit ratings.

\section{TIFIA lending program, United States}

The Transportation Infrastructure Finance and Innovation Act (TIFIA) lending programme was created in 1998, partially as a response to state and local government difficulty in obtaining finance on reasonable terms for transport infrastructure projects backed with user fees. TIFIA provides three forms of assistance: direct loans, loan guarantees, and standby lines of credit. Over 16 years, approximately USD 3 billion of federal funds were used to cover USD 21.8 billion of loans. Expanding the TIFIA programme has been identified as a key way to increase infrastructure investment in the United States.

Source: Bulgaria and Colombia (OECD, 2021[114]; OECD, 2017[115]) ; United States (Altman, Klein and Krueger, 2015[116])

\section{Access to project finance loans}

Project finance loans are used to support the construction phase of any type of infrastructure. Loan repayment terms, interest rates, and structures can be adjusted to reflect the requirements of the specific project. Interest rates might be fixed or floating, and are generally based on benchmarks such as the London Inter-Bank Offered Rate (LIBOR) or the Euro Interbank Offered Rate (EURIBOR) with a risk premium. The length of project finance loans are usually linked to the life of the project and can range up to 20-30 year in some rare cases (usually tied to PPP companies).

\section{Increasing the use of green loans}

Green loans have the potential to support a wide range of subnational government investments, particularly improvements in energy efficiency and clean transportation projects. These loans may be provided by 
external finance institutions, government financing agencies or multi-lateral finance institutions. The Loan Market Association issued Green Loan Principles, which provides a definition for green loans as "any type of loan instrument made available exclusively to finance or re-finance, in whole or in part, new and/or existing eligible Green Projects" (Loan Market Association, 2018[117]). Eligible types of projects include renewable energy, energy efficiency, clean transportation and climate change adaption projects (Hussain, $\left.2020_{[118]}\right)$. The International Finance Corporation (IFC) recently created a green loan product in line with the Green Loan Principles in 2018, and has issued a green loan to boost climate finance in Brazil to Sicredi, a cooperative financing institution, that will be used to help diversify the energy mix by supporting renewable energy projects (IFC, 2021 $\left.{ }_{[119]}\right)$. In China, the national government and the World Bank have implemented a lending programme to increase the accessibility to sustainable and long-term financing for green investments for local governments in in the Yangtze River Delta Region (Box 3.17).

\section{Box 3.17. Green Urban Financing and Innovation Project in China}

This project was signed by the national government of China and the World Bank in 2019 and will run until 2025. Loans received by the national government were made available to Shanghai (on-lending) to increase access to sustainable and long-term financing for selected green urban investments, benefitting local governments in the Yangtze River Delta Region. The main component of the project is the Facility Credit Line, which will provide initial low-cost long-term funding and accelerate the Shanghai Green Urban Financing and Services Co., Ltd (FSC) facility start-up. The Shanghai Municipality consists of the central city of Shanghai and nine suburban districts/counties. By April 2021, six local governments had benefitted from this initiative.

The key innovations of this project include that (a) the FSC will provide longer-tenor financing to urban environmental infrastructure projects and reduce refinancing risks that are typically seen in the current domestic market; (b) the FSC will pool the risk profiles of underlying projects, thus aggregating demand for lower-tier governments and reducing the overall portfolio risk, (c) the project aims at mobilising private capital through private equity participation in the FSC capital structure and syndicated bank loans and bonds issuances; (d) the project will prepare the FSC to introduce a new asset class of green bonds based on pooled assets in the subnational debt market (never previously done in China). The project aims to obtain credit rating and green bond principle certification for the facility by the end of the project in 2025.

Source: (World Bank, 2021 [120])

\section{Exploring opportunities for lease financing for assets related to infrastructure}

A form of financing involving a regular payment in return for use of an asset over an agreed period. Instead of purchasing an asset, which may require large upfront expenditure, governments may choose to lease assets over an extended period of time. Leases can sometimes include an agreement to purchase the asset at the end of the leasing period. While leases are not used for physical infrastructure, they are often used for high value assets that are part of infrastructure networks, such as train carriages or buses. Examples of lease financing are electric buses in Shenzhen, China (Box 3.18).

\section{Box 3.18. Electric bus leases in Shenzhen, China}

To reduce the upfront costs of renewing the bus network in Shenzhen, the Shenzhen Bus Group adopted a financing leasing model, where a leasing company purchases and owns electric busses, which are leased to the bus operating company over eight years, before being returned for recycling and disposal (Berlin, Zhang and Chen, 2020[121]). 


\section{Expanding the use of bonds}

Innovations relating to bonds are seeking to expand the use of bonds by subnational governments, which are currently an underutilised source of borrowing in many countries. Examples in this section include the use of municipal bonds, as well as green, climate, social and 'mini' bonds.

Increasing the use of bonds provides an opportunity to increase the ability of subnational governments to undertake infrastructure investment. While the bond market is already well established in, Brazil, Canada, China, India, Japan, Korea and the United States for municipal and State governments, it is also becoming a more common financing mechanism in Europe, (France, Germany, Italy, Spain, Sweden, and Norway, see Figure 3.5). In G20 countries, bonds and securities represent $27 \%$ of the subnational government debt stock (OECD/UCLG, 2019[14]). Globally, bonds and securities represent $12 \%$ of total subnational government debt.

In many countries, the use of bond financing may be limited for smaller subnational governments, particularly local governments. Among other areas, this can be due to the lack of a domestic capital market, fiscal rules forbidding or restricting bond issuance, or the lack of financial scale and capability. In some cases, smaller municipalities have joined together to issue bonds or are able to access bonds through dedicated financing institutions (see later section for details of investors).

Infrastructure investment can be supported by increasing subnational government access to bond markets, improving the depth of markets and innovating in the types of bonds offered. Bonds that provide opportunities for subnational governments to increase infrastructure investment include traditional bonds as well as "earmarked" bonds such as green bonds, climate bonds, social bonds and minibonds.

\section{Expanding the use of bonds and lowering their costs}

Expanding the use of bonds by subnational governments, especially outside of the United States, could support increased infrastructure investment. Municipal bonds are issued by municipal, regional or state governments to support general government finances or specific investment projects. The United States has a highly developed bond market, with a large variety in the types of municipal bonds available and a tax discount for investors in municipal bonds (Box 3.19 and (OECD, 2015[27])). The use of municipal bonds supports financial discipline because of external scrutiny of government finances and may help lower the cost of finance (Peterson, 2002[122]). National governments can play a significant role in supporting the local government bond market, such as the case in Japan (Box 3.19). 
44

Figure 3.5. Subnational government debt by instrument

Share of total outstanding debt $(\%, 2016)$

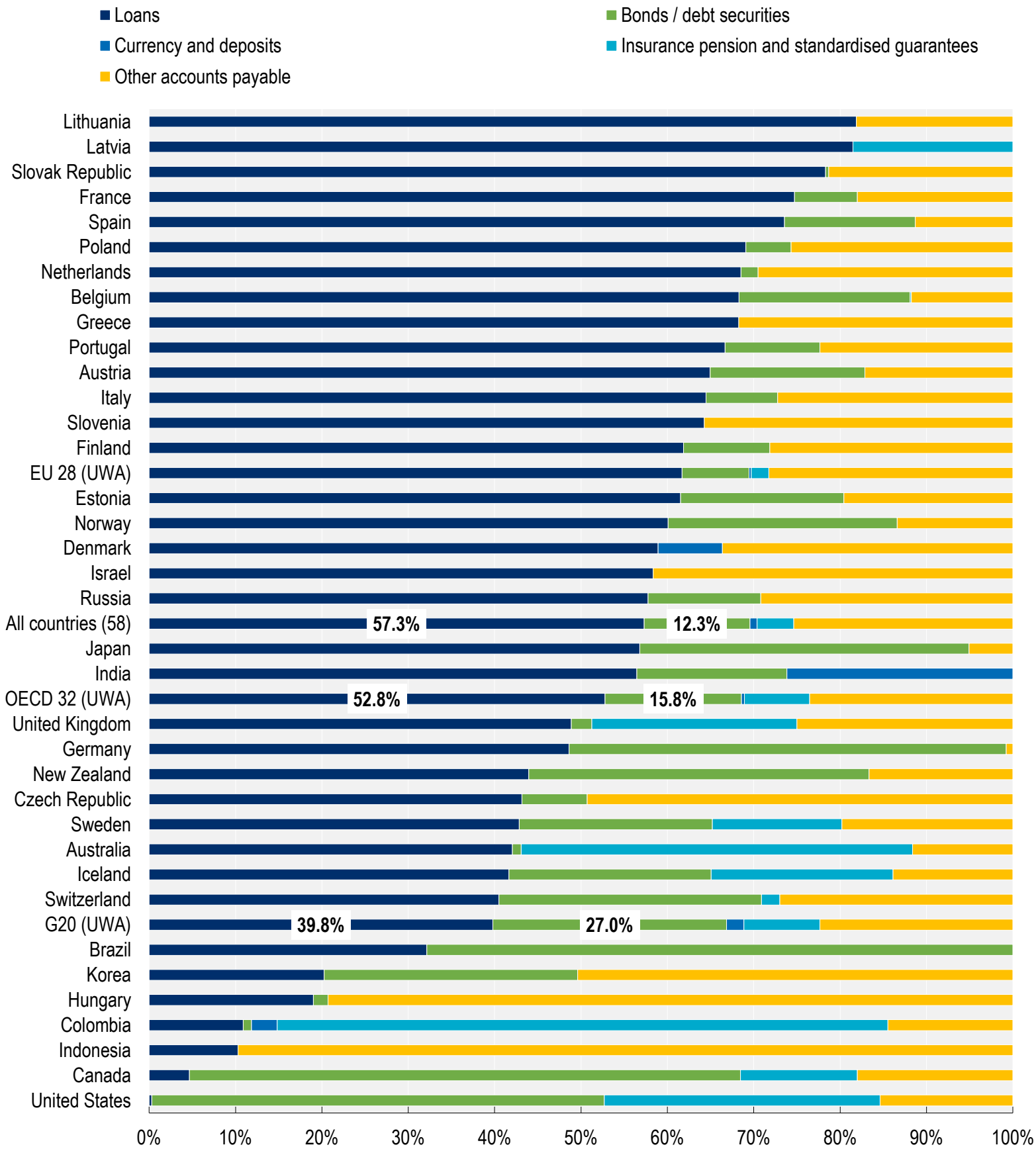

Source: Source: OECD-UCLG World Observatory on Subnational Government Finance and Investment (www.SNG-WOFI.org) (OECD and UCLG, 2019[12]) 


\section{Box 3.19. Municipal bonds in the United States and local government bonds in Japan}

\section{Municipal Bond Market in the United States}

The United States has the largest municipal bond market, with over USD 3.9 trillion in outstanding debt and over 50,000 issuers as of 2019. In many cases, municipal bonds are tax-free for United States resident investors. The municipal bond market includes a large variety of different bonds - 'general obligation bonds' and 'revenue bonds' are the two main types. General obligation bonds are an allpurpose bond that can be used to support municipal finances and are backed by the taxing authority of the issuer, and are not typically considered infrastructure finance (OECD, 2015[27]). Revenue bonds are project bonds that are repaid directly using revenues from a project, particularly from user charges and fees. Revenue bonds may involve a special purpose vehicle from which repayments are made.

One innovative form of municipal bond that has been promoted as a way to support increased infrastructure investment in the United States is the Build America Bond (BABs). These taxable bonds were issued by State and local governments between 2009 and 2010 and issuers received an interest rate subsidy from the United States Treasury. During the period that they operated, USD 181 billion were issued, which represented $21 \%$ of total municipal bond debt. The different treatment of tax broadened the number of investors who could access these bonds. During the period that they existed, analysis has indicated that BABs saved USD 20 billion in interest for municipal governments and lowered interest rates. In May 2021, the United States government proposed reviving BABs to support school building through new Qualified School Infrastructure Bonds.

\section{Japanese Local Government Bonds}

In Japan, the central government provides significant support to the local government bond system. First, the central government guarantees revenue resources to pay the interest and principal of local government bonds through the local public finance system. The payments of bonds are ensured through the local allocation tax. Specifically, the principal and interest cost of the local government bonds are included in the central transfers to local governments for covering the provision of basic public services and infrastructure. Second, the central government checks and controls the bond issuance. All local governments are required to consult with or notify the Minister of Internal Affairs and Communications (or the prefectural governor) before issuing Local Government Bonds. Local governments in deteriorating fiscal condition are required to obtain an approval for the issuance.

Source: United States (Altman, Klein and Krueger, 2015 $\left.{ }_{[116]}\right)$ (Salwati and Wessel, $\left.2021_{[123]}\right)$ (U.S. Treasury Department, 2011 $\left.{ }_{[124]}\right)$; Japan (Ministry of Internal Affairs and Communications of Japan, 2018[125]).

\section{Harnessing "earmarked": green bonds, climate bonds and social bonds}

Green bonds, climate bonds and social bonds provide an opportunity for subnational governments to access financing for certain types of infrastructure investments. Indeed, many types of projects undertaken by subnational governments, such as clean transport projects, pollution prevention and control, and environmentally sustainable management of natural resources and land use, are included in the definition of Green Projects by the Green Bond Principles (ICMA, 2021 ${ }_{[126]}$ ). Green bonds may be most promising when cities and national governments co-operate. In particular, where there are tax exemptions and subsidies for subnational governments to issue these bonds, as exists with municipal bonds issued in the United States (Merk et al., 2012[72]). For cities in low and middle-income countries, the World Bank offers green bonds as part of project financing, which requires national co-operation.

The use of green and social debt financing is growing and subnational governments are becoming increasingly active in this market. In 2020, USD 63.9 billion in green debt was issued by local governments' 
against USD 3.7 billion in 2014. Subnational government bond issuance represents $6 \%$ of the total green bond issuances in 2020. In some countries, such as France, Japan, Sweden and the United States, subnational governments are becoming significant issuers of green bonds or climate bonds. The region of Île-de-France in France has developed a green and sustainable bond issuance framework (Box 3.20). The City of Moscow in Russia and Washington DC in the United States have issued green bonds, including a unique Environmental Impact Bond (Box 3.20).

Similar to green bonds, social bonds are issued with defined public policy objectives, which can include supporting new social infrastructure or social programmes. The Social Bond Principals published by the International Capital Market Association provide a voluntary framework for social bonds (ICMA, 2021 [127]) that define specific requirements, including that funds for defined projects such as basic infrastructure and affordable housing. COVID-19 recovery are bringing these innovative and instruments into greater focus.

\section{Box 3.20. Green and social bond issuance by subnational governments in France, Spain, Russia and the United States}

\section{Green and sustainable bond issuance framework, île-de-France, France}

The Île-de-France Region is an early adopter of sustainable finance and globally, was the first to issue a sustainable bond in a public format (in 2012). More recently, the region has developed a framework for green and sustainable bonds that is compliant with the International Capital Market Association Green Bond Principles, Social Bond Principles and Sustainability Bond Guidelines. This framework defines what proceeds from green and sustainable bonds may be used for, the process for project evaluation and selection, the management of proceeds and the reporting and review requirements. In 2021, Île-de-France issued its first tranche under the updated framework for green, social and sustainable bonds in April 2021 and achieved a negative yield, highlighting its attractiveness.

\section{The first social bond in Spain by the Autonomous Community of Madrid}

The Community of Madrid, for the first time in Spain, turned to capital markets to raise funds to promote initiatives in support of the region's health system, given the impact of COVID-19. It will devote the EUR 52 million raised through a social bond to support the regional health system, under the umbrella of its recently renewed Sustainable Financing Framework, which envisages earmarking funds from the General Budget to finance social and environmental projects.

\section{City of Moscow Green Bond, Russia}

In May 2021, the Moscow Government issued RUB 70 billion worth of green bonds, which are to be spent on reducing the emissions of contaminants and greenhouse gases from Moscow public transport. These are the first green bonds issued by a government in Russia. The International Capital Markets Association (ICMA) included the bonds in the registry of sustainable development bonds.

\section{Environmental impact bond in Washington DC, United States}

In 2016, Washington DC's water and sewer agency issued an environmental impact bond, which pays investors a higher rate of return if key environmental objectives are achieved (or charges them a premium if they are not achieved). The bond's USD 25 million proceeds are for the installation of 'green infrastructure' to absorb surges of storm water during heavy rains, ultimately reducing the frequency and volume of sewer overflows that contaminate local rivers. The bond return is linked to the level of runoff reduction. If the reduction exceeds $41 \%$, compared to a baseline level, the agency will pay investors a bonus of USD 3.3 million. If at the end of a designated period the level of runoff reduction is less than $18.6 \%$, investors will make a 'risk share payoff' to DC Water totalling USD 3.3 million.

Source: (Region Île-de-France, 2021 [128]), (BBVA, 2020[129]), (WWF, 2021 [130]), (Goldman Sachs, 2016[131]). 


\section{Exploring opportunities for the use of minibonds}

Subnational governments continue to explore the use of minibonds to support local infrastructure investment. Minibonds are bonds with a lower denomination than traditional bonds that have sometimes been targeted towards local residents or groups of smaller investors. The lower-than-normal denomination, typically less than USD 1000 , means that the bonds can be more easily purchased by smaller investors than traditional bonds (which have a typical denomination of USD 5000 or higher). These bonds typically raise smaller amounts of funding than traditional bonds. One of the benefits of minibonds is that they can strengthen social capital by fostering a direct link between local investors and local governments; however, its issuance might come at a higher expense than larger municipal bond programmes that benefit from scale economies (Ely and Martell, 2016[132] $)$. A recent example of the use of a minibond is in Cambridge in the United States, which issued USD 2.5 million of minibonds to residents to fund local infrastructure projects. These Minibonds were issued with a denomination of USD 1000 and a fixed interest rate of $2 \%$ paid in five years to support building renovations, municipal facility upgrades and street upgrades (City of Cambridge, 2018[133]).

\section{Increasing the impact from equity}

\section{Innovations relating to equity seek to increase the economic, social and environmental impact arising from infrastructure investments. An example is in the potential use of 'impact investing' for infrastructure.}

Equity finance is sometimes adopted to support subnational government infrastructure investment, particularly through PPPs. Equity is capital-at-risk that is provided in return for an ownership share of an asset or entity $(O E C D, 2015[27])$. Equity investors may participate in infrastructure investment by becoming owners of a 'special purpose vehicle' that is set-up as part of a subnational PPP, by investing in private infrastructure companies, or by investing in subnational SOEs (where they are not $100 \%$ publicly owned).

One emerging area of equity financing that has the potential to become increasingly relevant for subnational infrastructure investment is 'impact investing'. With impact investing, investors seek to use investments to generate positive, measurable social and environmental impact, alongside a financial return (GIIN, 2020[134]). Impact investing is relevant for subnational governments because public infrastructure investment almost always has social and/or environmental impact. The 2020 Global Impact Investing Network (GIIN) impact investor survey reported $28 \%$ of impact investor assets under management were invested in infrastructure sectors (energy, housing and other infrastructure) and over $46 \%$ of impact investors had invested in infrastructure (GIIN, 2020[134]). The United Nations Office for Project Services (UNOPS) has recently developed its own impact investing initiative to encourage investing for impact in developing countries (Box 3.21).

\section{Box 3.21. UNOPS Sustainable Investments in Infrastructure and Innovation (S3I) initiative}

UNOPS has established a Sustainable Investments in Infrastructure and Innovation (S3I) initiative, which seeks to support impact infrastructure investing in developing countries. Through the S3I initiative, UNOPS aims to break down barriers and create opportunities for investors to generate financial returns with positive social, environmental and economic impacts. The initiative aims to help find innovative financing solutions to connect stakeholders to support new partnerships for sustainable development. Initiatives included in S3I are supporting investment in renewable energy, affordable housing, health infrastructure, innovation and digital solutions. Through this initiative, UNOPS has committed to help build more than 1.3 million homes over the next decade, in Ghana, Guinea, India, Nigeria, Kenya, Pakistan and across the Caribbean, and deliver green energy to an estimated 50000 people in Mexico (UNOPS, 2021 [135]). 


\title{
Diversifying the investors in subnational government infrastructure
}

\author{
Innovations relating to the types of investors can expand the diversity of investors in subnational government \\ infrastructure, which can help improve the accessibility of finance. Examples include the use of national \\ infrastructure banks, subnational pooled finance mechanisms and crowd-investing.
}

To support infrastructure investment, it can be beneficial for subnational governments to have access to a diverse range of financial institutions to provide different types of financing. These investors range from multi-lateral institutions, commercial banks, to local community financing platforms and subnational pooled finance mechanisms. Subnational governments have different ways to access credit markets in different countries. In some countries, access is restricted to public lenders (e.g. Ministry of Finance, national debt offices), while in others, municipalities can access to public and private sector finance, including from multilateral and public financial institutions and commercial banks, amongst other providers.

\section{Public financial institutions}

Public financial institutions may be established at a subnational, national and international level to support infrastructure investment or improve subnational government access to finance. They are typically created with an initial public capital injection, but may also leverage private finance by issuing bonds or accessing loans, which are then passed on to support subnational government investments. Financial institutions act as a revolving fund, where initial government capital is re-used for additional financing in the future.

Public financial institutions can have a core role in helping to make subnational government infrastructure projects more 'bankable' for the private sector, which can increase total investment. A common objective for public financing is to efficiently "crowding-in" private finance, rather than to replacing existing private finance with public finance.

Public finance institutions may target infrastructure investment, or may provide general financing to subnational governments. Three types of public financing institutions relevant to subnational governments presented in the follows are subnational pooled finance mechanisms, national infrastructure banks and multi-lateral institutions.

\section{Subnational pooled finance mechanisms}

Subnational pooled finance mechanisms are a promising approach to facilitate subnational government access to capital markets for infrastructure development. These mechanisms provide joint access to capital markets for subnational governments who have similar missions and credit characteristics but lack the financial scope and scale, expertise, and credit history to access credit markets on their own. They are particularly important for smaller municipalities or projects as they can help to mitigate debt service payment risk, diversify project risk, and provide the technical professional management required to enable sustainability and access to private finance. Beyond economies of scales, pooling demand for capital has a number of advantages, in particular higher volumes and liquidity, and diversified products, which can lead to significant cost benefits and improvement in terms for local governments (Andersson, 2014[136]).

A wide variety of subnational pooled finance mechanisms exist, including local government financing agencies, bond banks and other pooled finance facilities (FMDV, 2015 $\left.{ }_{[137]}\right)$. Local government funding agencies are common in Nordic countries (Denmark, Finland, Sweden, and Norway) and exist in other countries including as France, Japan, and New Zealand (Box 3.22). Other examples of pooled finance include Canada's Provincial-Municipal Finance Corporations, local infrastructure development funds in Viet Nam (Istituto Affari Internazionali, 2021 ${ }_{[6]}$ ), Bond Banks and State Infrastructure Banks (Box 3.22) in the United States and the Tamil Nadu Urban Development Fund in India (Box 3.22). 


\section{Box 3.22. Subnational pooled finance mechanisms in New Zealand, Japan, France, the United States and India}

\section{Local Government Funding Agency, New Zealand}

The Local Government Funding Agency was created in 2011 to provide efficient financing costs and diversified financing sources for the country's local authorities. This agency aims to optimise the debt funding terms and conditions for participating local governments. The agency issues debt and bonds on national and international markets, and then lends to local governments with a small margin to cover an administration fee. The funding agency is majority owned by councils and holds about $90 \%$ of New Zealand local government debt (Vammalle and Bambalaite, 2021 [138]).

\section{Japan Finance Organization for Municipalities (JFM)}

Japan Finance Organization for Municipalities (JFM) is a joint financing organisation that provides Japanese local governments with long-term finance at low interest rates. It was initially created in 1957 as a government financial institution but was transformed in 2008 into a non-profit organisation and is fully owned by local governments, including the 47 prefectures and a total of 1741 cities and special wards of Tokyo, government-designated cities, as well as towns and villages. Local governments must, in principle, receive consents or approvals of the Minister for Internal Affairs and Communications or their respective prefectural governors when they borrow from JFM. Within this structure, JFM has never had a default since its establishment. JFM plays a key role in the public sector finance at subnational level in Japan. In fiscal 2019, JFM provided loans totalling USD 15.3 billion, representing around 15\% of the Local Government Borrowing Programme defined annually by the national government. (JFM, $2020[139])$.

\section{Agence France Locale, France}

This local government agency was created by 11 subnational governments in December 2013 as a result of new banking legislation and is $100 \%$ owned by French local authorities. It was granted a banking license in January 2015. By the end of 2020, Agence France Locale had 411 shareholders including 2 regions, 10 departments, 12 metropolitan areas and 306 municipalities (representing 45\% of French population) and over EUR 4.3 billion of loans had been granted since 2015 (AFL, 2020[140]).

\section{State Infrastructure Banks, United States}

In the United States, over 30 State Infrastructure Banks were established in the 1990s to support infrastructure investment in States. These banks were established as revolving funds with matching federal and State government capital, and could provide loans and credit enhancement support to infrastructure projects (U.S. Department of Transportation, n.d.[141]). The banks have provided billions in financing for more than 1000 projects; however, the banks are currently underutilised or inactive in many states. They remain a potentially valuable tool for supporting the delivery of local infrastructure (Puentes and Thompson, 2012[142]).

\section{Tamil Nadu Urban Development Fund, India}

This Fund was established by the Government of Tamil Nadu to finance the implementation of urban infrastructure projects in the State of Tamil Nadu. The Fund leverages funding from external agencies, including the World Bank, KfW (German Funding Agency), Japan International Cooperation Agency and Asian Development Bank. Loans are then provided to urban local bodies or water supply and sewerage boards for infrastructure projects (TNUIFSL, n.d.[143]; Istituto Affari Internazionali, 2021 [6]). 


\section{National infrastructure banks and funds}

National infrastructure banks and funds can have a key role in improving access to finance for subnational governments infrastructure investment. They can be long-term investors in public infrastructure, mobilise private finance for infrastructure investment and support investment in renewables and the green economy (Global Infrastructure Hub and CEPA, 2019 $[144]$ ). National infrastructure banks and funds may provide a wide range of financial products, including debt, equity, credit enhancement support, as well as project advisory support. Examples of infrastructure banks include the PT Sarana Multi Infrastruktur (Indonesia), Fondo Fiduciario Federal de Infraestructura Regional, and, most recently, the UK National Infrastructure Bank (Box 3.23).

\section{Box 3.23. National infrastructure banks and funds in Indonesia, Argentina and the United Kingdom}

\section{PT Sarana Multi Infrastruktur, Indonesia}

This bank was created in 2009 to catalyse infrastructure investment in Indonesia. The bank's mandate is to optimise the social and economic benefits of infrastructure for communities and support the achievement of the Sustainable Development Goals. The Bank harnesses equity and debt from the Government of Indonesia, alongside loans from multi-lateral institutions and private sector banks, and bond issuances (including green bonds) to provide financing support, advisory services and project development to subnational governments and specific intrastructure projects (Global Infrastructure Hub and CEPA, 2019 $[144])$. Supporting municipal financing projects is one of the many activities undertaken by the Bank.

\section{Fondo Fiduciario Federal de Infraestructura Regional, Argentina}

This is a local infrastructure fund that lends to provinces overseen by the Ministry of Interior in Argentina. The fund finances relatively small infrastructure projects with high impact on local communities, such as street paving, school construction and water treatment plants. It lends directly to provincial governments (and through them to municipalities), using revenues from federal tax co-participation funds as collateral. The fund does not have annual budget support and achieves full cost recovery by charging market-based interest rates and a fee for technical assistance. It received USD 448 million in capitalisation and lends approximately USD 2 billion.

\section{UK National Infrastructure Bank}

The bank is being established with a goal to help tackle climate change and support regional and local economic growth. It has been established with GBP 22 billion of financial capacity, including GBP 12 billion of equity and debt capital, and the ability to issue GBP 10 billion of guarantees for infrastructure projects. For high value and strategic projects, the bank will offer low interest loans to local authorities at a defined rate. It will also have an advisory function to support local authorities to develop projects.

Source: PT Sarana Multi Infrastruktur, Indonesia (Global Infrastructure Hub and CEPA, 2019[144]), Fondo Fiduciario Federal de Infraestructura Regional (World Bank Group and Inter-American Development Bank, 2019 $[145]$ ), and National Infrastructure Bank (HM Treasury, 2021[146]; National Infrastructure Commission, 2018[147])

\section{Multi-lateral institutions and funds:}

A large number of institutions and funds operate at an international level to support local infrastructure projects. These include multiple United Nations funds, the World Bank Group, multilateral development banks (i.e. African Development Bank, the Asian Development Bank, the European Bank for Reconstruction and Development, the Islamic Development Bank, and the Inter-American Development 
Bank), and vertical funds that combine public and private sector finance (OECD, 2020[148]). One example is the Natural Capital Financing Facility established by the European Investment Bank (Box 3.24).

\section{Box 3.24. The Natural Capital Financing Facility (NCFF)}

A EUR 100-120 million revolving fund that supports projects promoting biodiversity and nature-based climate adaptation in European cities. The NCFF provides project loans and equity investments (between EUR 2-15 million during the pilot phase) and project preparation support. The fund supports green and blue infrastructure projects from businesses or government agencies. It is funded by the European Investment Bank and the European Union's LIFE Programme.

For example, in 2018, a EUR 5 million NCFF loan financed the integration of green components into the restoration of public squares and streets, creating green corridors between different areas and natural restoration of Athens second landmark hill after the Acropolis, Lycabettus Hill. The objective of this operation was to support the implementation of the Athens Resilience 2030 Strategy and thus contribute to reducing urban heat islands, increase natural water infiltration and improve the overall attractiveness of the project areas. This loan is attached to a EUR 55 million framework loan for resilient urban renewal and development to the Municipality of Athens.

Source: (EIB, 2018[149])

\section{Private and institutional investors}

A diverse range of private investors support subnational government infrastructure investment. These investors can invest by supporting general subnational government finances or by providing targeted project finance. They can also invest indirectly through intermediaries. Direct investors typically include commercial banks and private equity, and indirect investors are typically large institutional investors, such as pension funds, sovereign wealth funds, insurance companies, private equity, endowments and family offices.

Commercial banks have traditionally been the main private loan providers for subnational government infrastructure. Commercial banks can provide loans directly to municipal governments, to a special purpose vehicle (as is set up for a PPP) or to a state-owned enterprise (SOE). After the 2008 global financial crisis, reforms of the finance sector have placed higher liquidity controls on banks, meaning that commercial banks are providing less long-term infrastructure lending (Kim, 2016 $\left.{ }_{[84]}\right)$. As a result, loans from institutional investors (especially pension funds and sovereign wealth funds) and private debt funds have a more important role in providing infrastructure finance, especially for PPPs (Kim, 2016[84]).

Private equity are one of the main equity investors in infrastructure projects. These investors may invest directly in a subnational government infrastructure project, through a special purpose vehicle, or in a stateowned enterprise (SOE) (if it has less than $100 \%$ public ownership).

\section{Community funding and financing for small-scale infrastructure}

Online crowdfunding or crowd-investing platforms provide an emerging opportunity to raise funding or financing from community donors or investors, and can help subnational governments direct funding to local community infrastructure projects. Community members or governments can use these platforms to seek funding for projects or to give small philanthropic grants or investments to projects. While donationbased crowdfunding platforms are more common, a range of crowd-investing platforms have been emerging to provide an alternate approach to financing investments.

Crowdfunding is commonly used for small-scale community infrastructure projects (i.e. improving local streets or parks) where the projects are proposed and led by local community members. An alternate use 
of crowdfunding platforms is for the distribution of subnational government grants. In the United Kingdom, for example, local councils have used platform such as Spacehive to help distribute grants to community projects (Box 3.25). Using these platforms, community members can upload diverse projects, for which the local government can assess and decide to contribute funding, alongside other community donations. This may help mobilise other community funding, by encouraging co-contributions.

Crowd-investing provides an opportunity for subnational governments to raise finance. These platforms allow investors to make debt or equity investments in subnational governments (or businesses). Crowdinvesting has the potential to provide an alternate approach where individual investors support community infrastructure and services through small scale investments. Abundance investment, for example, has supported small scale investments in local council debt and the issuing of a green bond in the United Kingdom (Box 3.25).

\title{
Box 3.25. Crowdfunding and crowd-investing platforms in the United Kingdom
}

Spacehive (www.spacehive.com): A donation based funding platform for projects that brings "local places to life" such as improving local park and playgrounds, and supporting local community projects. Spacehive has delivered 1700 projects with GBP 22 million of funding, which has resulted in 8000 acres of space improved. Projects may be initiated by the community, but local governments can provide donations to support the projects. Since 2015, the Lewisham Council in the United Kingdom has used Spacehive to distribute community grants for voluntary and community sector organisations by allocating existing resources to ideas that were uploaded on the platform. As of August 2021, The council has supported 47 projects with nearly GBP 600000 of funding. By $2018,20 \%$ of UK local councils had backed a project on Spacehive (Spacehive, 2021[150]).

Abundance investment (www.abundanceinvestment.com): Platform for individual investors, with investments amounts as low as GBP 5, to invest in debt from businesses or local councils developing green infrastructure. Abundance partners with local councils to offer Community Municipal Investments (CMIs), which allow individual investors to invest directly in council led projects. An example of this was a GBP 1 million green bond investment with the Warrington Borough Council to support a 20MW solar and battery system (abundance, $\left.2021_{[151]}\right)$.

\section{Innovations in investment approaches}

The 'investment approach' refers to how funding and financing are used to deliver infrastructure. Typical investment approaches used by subnational governments include traditional public procurement, stateowned enterprises (SOE) and public-private partnerships (PPP). This section focuses on the use of subnational SOEs and subnational PPPs, which may help unlock funding and financing sources for certain investments. Although traditional public procurement is a key investment approach, which can harnesses both funding and financing, it is not highlighted here as it is common practice for subnational governments.

\section{Enhancing the use of subnational state-owned enterprises for infrastructure delivery}

\author{
Innovations in the use of subnational state-owned enterprises (SOEs) seek to improve the delivery of \\ infrastructure investments and may improve access to finance. Examples highlight the use of infrastructure \\ delivery agencies, redevelopment authorities and infrastructure operators.
}

In many countries, subnational state-owned enterprises - such as municipally-owned corporations and local public companies - have a key role in undertaking infrastructure investment and operating 
infrastructure. While there has been significant privatisation and a decline in state-ownership over recent decades, national and subnational government SOEs continue to account for about $20 \%$ of investment and $5 \%$ of employment globally (Asian Development Bank, $2020_{[152]}$ ). In many countries, SOEs have a key infrastructure investment role and responsibility for mega-infrastructure projects (Ju Kim and Ali, 2017[153]). In emerging markets and low-income developing countries, SOEs are responsible for $55 \%$ of infrastructure investment, as compared to $28 \%$ of investment by public entities (treasuries, ministries) and $17 \%$ by the private sector (World Bank, 2017[154]).

At a national level, reasons given by governments for establishing SOEs include a range of policy objectives, such as supporting economic and strategic interests, supplying specific public goods or services where market failures exist, or maintaining a state-owned monopoly when market regulation is deemed infeasible or inefficient (OECD, 2018[155]). Where they are established, governments should seek to ensure that SOEs operate effectively. Better governance and a stronger rational for public intervention can correlate with higher performance (OECD, 2015[156]; IMF, 2020[157]).

Subnational governments SOEs are known by a diverse range of names in different countries, including municipally-owned corporations, local public enterprises or companies or authorities, government corporations and semi-public companies. The number of subnational SOEs has been increasing in many countries. In Europe, the number of local public enterprises doubled between 2008 and 2020, increasing to nearly 32000 , especially in Germany, Austria, France, Italy, and Spain. In Sweden and Germany in 2013 , for example, county and municipality-owned SOEs comprised $74 \%$ and $89 \%$ of all SOEs (pwc, $\left.2015_{[158]}\right)$. In France, there are approximately 1330 subnational SOEs and in Japan there are around 8700 local public companies and they are particularly active in investing in local infrastructure including sewerage ( $42 \%$ of total), water supply $(24 \%)$ and hospitals $(7 \%)$.

Subnational governments seek to use SOEs to help professionalise infrastructure delivery and asset management, and improve access to finance. Even where subnational SOEs are completely owned by governments, they can operate independently from government through clear governance arrangements, such as independent board members and audit processes. This can help to ensure the independence of decisions and the application of different management practices. The use of SOEs for infrastructure investment may be alongside a public-private partnership model, or be used as an alternate to a publicprivate partnership. In a study, on the use of SOEs for infrastructure delivery in Denmark, the use of new $100 \%$ publicly-owned SOE was perceived to outperform other market-based solutions (Christensen and Greve, 2018[159]).

A large number of subnational SOEs exist throughout the world with different roles and responsibilities. The types of SOEs established by subnational governments that support or undertake infrastructure investment include redevelopment agencies, utility companies (i.e. water, sewerage, energy, waste), public transport providers, infrastructure delivery authorities and public financial institutions, among many other types of SOEs. In the State of Victoria in Australia, a Major Transport Infrastructure Authority was established outside of the Victorian Department of Transport to plan, procure and manage AUD 80 billion of infrastructure investment (Box 3.26). In Denmark, the Copenhagen City and Port Development Corporation was established to oversee urban redevelopment and coordinate land and infrastructure investments to increase the value created from these integrated developments (Box 3.26). In China, the MTR Corporation is responsible for managing the operation of the rail network in Hong Kong (China), but also operates other international rail networks (Box 3.26). 


\section{Box 3.26. Subnational state-owned enterprises in Australia, Denmark and China}

\section{Major Transport Infrastructure Authority, Victoria, Australia}

This Authority was established by the Victorian State Government in Australia to oversee major road and rail projects, representing approximately AUD 80 billion in forecast investment under the Victorian Government "Big Build" programme. The Authority was established to be separate to, but work closely with, the Department of Transport. The authority brings together expertise in infrastructure planning, financing and delivery into a single authority, which can allow for the sharing of resources, systems, tools and knowledge across major projects. Infrastructure investments by the authority are being undertaken through a mix of traditional public procurement approaches and public private partnerships, leveraging funding from the national and State government and private finance.

\section{Copenhagen City and Port Development Corporation, Denmark}

The City of Copenhagen established an urban redevelopment agency to use revenues from urban redevelopment project to fund and finance the construction of infrastructure. The corporation uses funds from the sale of public land and assets to invest in a range of infrastructure, including public transport, roads and recreational facilities. The corporation uses land value capture mechanisms, smart land valuation techniques and low-cost financing, with land assets as collateral and supported by city's AAA credit rating. The corporation operates as a strategic asset manager, staging and sequencing the sale of land and property to maximise value created. Improvements in infrastructure increase the bidding price of assets. For one of its largest assets, the North Harbour, the corporation was able to increase the value of the land by EUR 450 million more than an original estimate.

\section{MTR Corporation, Hong Kong, China}

The MTR Corporation is $75 \%$ owned by the Government of the Hong Kong Special Administrative Region (China) and is responsible for operating railway networks in Hong Kong, Macau, Shenzhen, Beijing and Hangzhou in China, and other international cities like London, Stockholm, Melbourne and Sydney. In Hong Kong (China), MTR has a key role in planning, constructing, financing, maintaining and operating rail infrastructure, which is one of the only metropolitan rail networks in the world that is profitable without government funding support. To support the expansion of the rail network in Hong Kong (China), MTR Corporation uses a "Rail plus Property" model, where MTR purchases land development rights from the government based on an assessed value without a rail line, and then partners with property developers to build properties near the rail line. MTR receives profits from these properties, which support operations and maintenance.

Sources: Victoria, Australia (State Government of Victoria, 2021 [160]) Copenhagen, Denmark (Katz and Noring, 2017[161]), Hong Kong, China (McKinsey, 2016[162])

\section{Evolving subnational public-private partnerships}

\section{Innovations relating to use of public-private partnerships (PPPs) highlight evolving approaches in the use of PPPs at a subnational-level. Examples include the use of government equity participation in a PPP and a model for PPP cooperation between municipalities.}

Public-private partnerships (PPPs) bring together funding and financing to support infrastructure investment and operation. Although PPPs represent a relatively small component of total public infrastructure investment in many countries, they are an important investment approach that subnational governments often use to develop and operate infrastructure, which can harnesses private financing. 
In most OECD countries, national and subnational PPPs represent less than $5 \%$ of the total value of public sector infrastructure investment, although this increases to above $10 \%$ in some countries (OECD, 2018[163]; OECD, 2019 $\left.{ }_{[164]}\right)$. For example, in the UK in the twenty years up to 2018 , capital investment through private financing initiative models (PFl/PF2) averaged GBP 3 billion per year out of a total GBP 50 billion investment in infrastructure (UK National Audit Office, 2018[165]). Approximately $50 \%$ of this was at a subnational level (devolved and local authorities), 23\% was through the National Health System and the remainder through the national government $\left(\mathrm{OECD}, 2018_{[163]}\right)$. While the average value of PPPs tends to be higher at a national level, subnational governments are responsible for a larger number of PPPs than national governments (OECD, 2018[163]). In Australia and Germany, for example, approximately $90 \%$ and $80 \%$ of PPPs occur at the subnational level, respectively (OECD, 2018[163]). In the UK, the average PFI value at a local authority level was GBP 56 million, versus GBP 158 million at a central government level.

A wide variety of different types of PPPs exist and the definition of a PPP varies across countries. A broad definition is that a PPP is "a long-term contract between a private party and a government entity, for providing a public asset or service, in which the private party bears significant risk and management responsibility, and remuneration is linked to performance" (World Bank Group et al., 2017[166]).

PPPs have benefits, costs and risks for subnational governments that need to be carefully assessed. PPPs are usually considered justified where they are affordable and produce greater value for money than would be provided by the delivery of public services or investment through traditional means (OECD, 2018 ${ }_{[163]}$ ). The OECD Principles for Public Governance of PPPs outlines that when deciding whether to use a PPP, governments should "carefully investigate which investment method is likely to yield most value for money" and consider "key risk factors and characteristics of specific projects" (2012[167]). The World Bank recommends that subnational governments assess how PPPs factor into broader planning and budgeting systems, and ensure adequate processes are in place for effective use of public resources (2021 [168]).

This means that subnational governments need to carefully evaluate the benefits, costs and risks of PPPs against other infrastructure delivery models. Potential benefits provided by PPPs might include an increased ability to harness sources of funding and financing (particularly in cases where a private provider is better able to introduce user charges and fees than a subnational government), enhanced project selection due to private sector analysis and innovation, and improved lifecycle management due to long-term incentives (World Bank Group et al., 2017 $[166])$. Subnational governments should consider if gains from these factors outweigh the cost of private finance and risk associated with PPPs (World Bank Group et al., 2017[166]). Properly undertaking this assessment of the benefits, costs and risks requires substantial public sector capability at a subnational government level, which can be beyond the capacity of many subnational governments, especially smaller ones (OECD, 2018[163]).

Financial risks for subnational governments relating to the use of PPPs are important to consider. This includes a risk that PPPs are used to bypass public financial management controls, creating higher longterm fiscal risks (World Bank Group et al., 2017[166]). For some subnational governments, the accounting (statistical treatment) of a PPP could be an factor that they consider when to undertake PPP (Eurostat, 2016[169]), which could potentially come at the expense of sound project preparation and value for money, and can also create an "affordability illusion" (Eurostat, 2016[169]). Even small PPP projects do not necessarily mean small liabilities, so consideration should also be given to the full extent of fiscal liabilities.

Governments at all levels are continually evolving PPP frameworks, models and processes to adapt them for specific projects or local contexts. These evolutions can seek to overcome perceived weaknesses from previous experiences, improve outcomes, expand PPP use or reduce costs. In the United Kingdom, for example, the national government has recently moved away from supporting the use of the private finance initiative (PFI) model, which is a form of PPP (Box 3.27). In place of the PFI, the government is now exploring other models, such as the expanded use of a 'regulated asset base' model and other approaches to support private sector involvement in infrastructure investment. Separately, at a subnational level, the devolved Welsh Government developed a specific Welsh Mutual Investment Model (Box 3.27). 


\section{Box 3.27. The evolution of public private partnerships in the United Kingdom}

\section{The end of the Private Finance Initiative in the UK}

The private financing initiative (PFI) model was launched in 1992 and was used in the UK for 20 years to help build and maintain new infrastructure, including schools, hospitals, roads and prisons. The PFI was a form of availability PPP, where the private sector was typically responsible for construction, financing, operations and maintenance of new infrastructure, in return for a payment for making the asset available. The PFI was particularly common at a subnational level (OECD, 2018[163]).

After the declining use of PFIs in the UK following the 2008 financial crisis, the UK government introduced a new model of PFI - PF2 - in 2012. The model sought to improve the procurement processes, exclude 'soft' services (such as catering and cleaning, which could be subject to change at short notice), reduce the role of bank debt, improve transparency and increase the proportion of risk carried by the public sector. Separately, in 2017, the devolved Welsh Government developed an alternate form of PPP, the Welsh Mutual Investment Model.

PF2 was used for 6 projects before, in the 2018 UK Budget, the UK Chancellor announced the abolishment of the PFI/PF2. This decision was made following declining use of PFIs and because the model was considered "inflexible and overly complex" and a "risk to government finances". The decision referred to a 2017 report from the Office of Budget Responsibility, which outlined fiscal risks posed by private finance initiatives being used for off-balance sheet financing and a 2018 report from the UK National Audit Office, which noted that there was a lack of data on the benefits of PFIs.

In the 2020 National Infrastructure Strategy, which was informed by an Infrastructure Finance Review public consultation, the UK government confirmed that it will not reintroduce the PFI model but will instead "develop new revenue support models and consider how existing models - such as the Regulated Asset Base model and Contracts for Difference - can be applied in new areas".

\section{Exploring the potential of the Regulated Asset Base model}

The Regulated Asset Base (RAB) model may provide an alternate approach to support private participation in the infrastructure sector to PPPS (ITF, 2015 $\left.5_{[170]}\right)$. It has been commonly used to supporting private participation in utilities in the United Kingdom. Under this model private infrastructure companies invest in infrastructure and a regulator supports a financial return based on a defined formula. The model has recently been adapted for use with the Thames Tideway Tunnel, a new $25 \mathrm{~km}$ sewerage tunnel in London with a total expected cost of GBP 4.2 billion.

Source: (Tideway, 2020[171]; ITF, 2015[170]; HM Treasury, 2019[172]; Zhivov, 2018[173])

\section{The Welsh Mutual Investment Model}

In 2017, the Welsh Government launched a new form of public private partnership, known as the Welsh Mutual Investment Model (MIM). The MIM is a form of availability-based PPP under which private partners can design, build, finance, operate and maintain new public assets. The MIM is distinct from the UK PFI model and is characterised by features including the opportunity to take a minority equity stake (up to a maximum of $20 \%$ of issued capital), the ability to provide for "third party equity" funding competitions at preferred bidder stage, and the right of the Welsh Government to appoint a director to the Board and the option for the managing authority to appoint an observer to the Board. The MIM has supported three projects in Wales: the 21st Century School Programme, the A465 Major Road Scheme and the redevelopment of the Velindre Cancer Centre in Cardiff.

Source: (HM Treasury, 2018[174]; HM Treasury, 2020[175]; Office for Budget Responsibility, 2017[176]; UK National Audit Office, 2018[165]; OECD, 2018[163]) 
Subnational governments, particularly municipal-level governments often have smaller projects (e.g. under USD 5 million equivalent), which can make the use of PPPs more challenging. According to the World Bank, several mechanisms can be deployed to mitigate challenges for municipal governments, such as simplifying approval process for small PPPs, developing standard processes and documents to make similar types of small projects easier and cheaper to prepare and deliver, as well as aggregating small projects $\left(2021_{[168]}\right)$. The Pennsylvania Department of Transportation, for example, aggregated the construction and maintenance of a few hundred small bridges into a single PPP project under its old bridges rehabilitation programme. This helped to create a larger PPP from smaller projects that would have not been viable as a PPP individually given that the average cost was as low as approximately USD 2 million (IISD, 2020[177]).

The use of PPPs can be supported through cooperation, upper-level government funding and capacity building. In Mexico, for example, multiple Municipalities cooperated to support infrastructure investment in a new biogas plant in Nuevo León, Mexico (Box 3.28). In India, the Viability Gap Scheme in India provides grants to economic-viable, but financial not-viable PPP projects at a subnational level, only where a PPP model is adopted (Box 3.28). Credit enhancement programmes and capacity building programmes targeted at subnational governments are other common forms of upper-level government support for subnational PPPs. In Korea, for example, the Public and Private Infrastructure Investment Management Centre (PIMAC) established a Public-Private Partnership Unit that provides technical assistance to subnational governments (Kim and Dougherty, 2020[47]).

\section{Box 3.28. Municipal government cooperation and national government support for the use of PPPs in Mexico and India}

\section{Municipalities as PPP partners: the biogas plant in Nuevo León, Mexico}

A biogas plant in the landfill located in Salinas Victoria, Nuevo León, Mexico was developed through a PPP, led by the state government. In addition to the two main investors to its special purpose vehicle (BENLESA), seven municipalities and three governmental agencies entered into associated agreements as partnered members of the PPP. This occurred as the Public Energy Service Law stipulated that permission for public or private partner investors to form an energy co-generation company could only be given if the energy generated by the plant would be sold to the partnered members. To comply with the law, municipalities signed 5-year independent power production contracts with the BENLESA, becoming both the power purchasers and the official partners. They are the only entities authorised to purchase the energy produced by the plant. The plant supplies almost $60 \%$ of the energy needed to power the Monterrey Metropolitan Area's public street lighting, public buildings and drinking water pump, as well as $80 \%$ of Monterrey's transportation system energy requirement.

\section{National government funding support: Viability Gap Funding in India}

In 2020, the Indian Government renewed a Viability Gap Funding scheme to support social and economic infrastructure and promote the use of Public-Private Partnerships. The fund allocates up to $30 \%$ of the Total Project Cost of project in funding, which may be supported by additional funding from State governments, sponsoring ministry or statutory entities. The scheme is focused on attracting more PPP projects and facilitating the private investment in social sectors (Health, Education, Waste Water, Solid Waste Management, Water Supply etc.).

Source: (World Bank, 2021 [168]); India (Indian Ministry of Finance, 2020[178]). 


\section{Tackling subnational infrastructure funding and financing challenges}

The access and use of innovative funding and financing tools depends on appropriate framework conditions being in place. This section highlights four key areas that policy-makers can focus on to create an enabling environment for subnational governments to leverage innovative funding and financing:

6. Reinforcing subnational government fiscal autonomy and financial capacity

7. Building subnational government investment capacity

8. Enhancing coordination and cooperation among and across levels of government

9. Establishing enabling regulatory and legal frameworks

In addition to these areas, further recommendations for supporting subnational government investment can be found in the OECD Recommendation on Effective Public Investment Across Levels of Government $\left(2019_{[2]}\right)$, the Recommendation on the Governance of Infrastructure $\left(2020_{[16]}\right)$, as well as the OECD Implementation Handbook for Quality Infrastructure Investment (2021 $\left.{ }_{[10]}\right)$, among other publications.

\section{Reinforcing subnational government fiscal autonomy and capacity}

\section{Fiscal frameworks, which incorporate the fiscal relations and rules between national and subnational governments, are needed to support subnational infrastructure investment.}

Inter-governmental fiscal frameworks and rules define the assignment of revenue, expenditure, budget balance and debt, and define the financial autonomy of subnational governments. The ability of subnational governments to increase revenue to fund infrastructure investment is primarily affected by three factors. The first is fiscal autonomy. This refers to the level of control that subnational governments have to raise revenues, manage spending and access borrowing. The second is the size of the tax base, which is closely linked to the population, economic growth and productivity of a jurisdiction. The third is the stability and pro-cyclicality of taxes and inter-governmental transfer revenue, in particular the share of earmarked grants versus block grants, and their predictability.

The level of fiscal autonomy is indicated by the share of own-source revenue (local taxes, user charges and fees, etc.) as a proportion of total revenue, as well as the extent to which subnational governments can increase or decrease their tax base or rates (for the fiscal autonomy of subnational governments in different countries, see OECD tax autonomy indicators $\left(2021_{[13]}\right)$ ). In many cases, the ability of subnational governments to change the tax rate or the tax base is constrained by national legislation and regulations.

The stability and cyclicality of taxes and grants is another important component of subnational government fiscal capacity for investment. National governments may give either discretionary or formula-based grants or subsidies to subnational governments. Discretionary grants are likely to be pro-cyclical as upper-level governments tend to reduce these grants when they face financial difficulties. However, they can also be stabilising when they are administered to increase funding during negative economic cycles. For example, 
many national governments have used discretionary transfers to support subnational governments during the first phase of the COVID-19 crisis. These transfers have acted as budget stabilisers for regional and local governments, including to maintain or increase investment to support the recovery (OECD, $2021_{[9]}$ ).

Increasing subnational government spending autonomy is a challenging task. Subnational governments often have little room for manoeuvre to reduce or freely allocate their spending, including towards investment. In the field of investment, subnational governments may sometimes act on behalf of the national government, with limited decision-making power on the choice of investment allocation. In these cases, subnational governments may simply be a "paying agent", acting more as an "investment agency" that is funded and regulated by a national government, rather than independent policy makers. The financial capacity of subnational governments for infrastructure investment, therefore, also depends on the nature and control over expenditure, and their ability to reduce it. This highlights one opportunity to increase funding for infrastructure, which is for subnational governments that they can use savings from within existing budget resources if they have control.

An appropriate fiscal framework is also the first step to improving the creditworthiness of subnational governments and unlocking financing for public infrastructure investment. Creditworthiness can be strongly affected by the ability of subnational governments to collect revenue and by fiscal rules. The most frequent fiscal rules for subnational governments (in particular for local governments) are a balanced budget requirement and 'golden rules', which restrict borrowing to capital investment. Other prudential rules on debt stock and services are also frequent, including the need for prior approval to borrow from a supervisory authority, caps on outstanding debt and debt service, limitations for new annual borrowing, bans on foreign debt, and bans on bond financing. Conditionality may also be attached to borrowing, or the use of debt may be restricted to large cities. National fiscal frameworks should ensure that there is sufficient fiscal space for investment, with appropriate fiscal rules that provide some borrowing capacity.

\section{Building subnational government investment capacity}

\section{Subnational governments need internal capacity to support and manage infrastructure investment throughout the lifecycle, including to deploy innovative funding and financing mechanisms.}

Deploying innovative funding and financing instruments require substantial subnational government capacity, including to complying with regulations, access external financing, undertaking procurement processes, to designing project delivery approaches (i.e. public private partnerships) and manage construction contracts. Capacities for effective management of public investment cover all stages of the investment cycle, from planning and project selection, financing and budgeting, to implementation and evaluation (Allain-Dupré, Hulbert and Vincent, 2017[179]), some of which are highlighted below.

During the infrastructure planning phase, subnational governments plan potential investments that can address economic, social and environmental objectives. As part of this process, they should engage in planning that is tailored, results-oriented, realistic, and coherent with national objectives. In particular, subnational governments can adopt holistic 'place-based' approaches, which coordinate infrastructure investments with other policy interventions. This can help to maximise the impact of infrastructure investment and address complex, multidimensional challenges of regions. This planning should be undertaken in consultation with local communities and stakeholders, which is key to understand infrastructure needs from the very early stages of the infrastructure life-cycle and ensure that the project pipeline adequately responds to those needs (OECD, 2020[16]). Planning can also help to maintain a sufficient future 'pipeline' of investments, which can maintain an efficient local construction industry.

Financing and budgeting requires linking the infrastructure investment plans with multi-annual budgets, considering other budget priorities. For infrastructure investment, this often requires the preparation of business cases, which are subject to internal or external review. Increasing the transparency of business 
cases and budgets can help provide visibility to planned investments, clarify future budgetary impacts associated with new infrastructure investment (i.e. from operations and maintenance expenses) and increase public accountability. Participatory budgeting, in particular, has been used by municipalities to support investment that is responsive to citizen needs and preferences. There are numerous examples of Participatory Budgeting at the subnational level, including in Porto Alegre, Brazil, which was the first city to implement this practice (OECD, 2019 $[1])$.

Lack of sufficient human resources and appropriate expertise is one of the main capacity challenges for infrastructure investment among many subnational governments, for especially small municipalities. Subnational governments can face difficulties attracting this type of expertise, particularly when there is high competition with the private sector. This risks generating an imbalance in knowledge between the public and private sectors, which may reduce trust between these actors. To overcome this, subnational governments need to be appropriately empowered and able to hire and manage staff according to needs (Dorothee Allain-Dupre, Isabelle Chatry and Louise Phung, 2020[180]). In addition, subnational governments need systematically build internal capabilities through training programs and guidelines. In Korea, for example, the Local Government Officials Development Institute contributes to the development of local administration bodies through various education and training programmes (Kim and Dougherty, 2020[47]).

Subnational governments can also pool expertise or seek external support to increase project finance and infrastructure investment expertise. At a subnational level, governments may create an internal project financing or PPP unit that brings together expertise to other government agencies. At the national and international levels, national infrastructure banks and multilateral development banks may establish teams or facilities to support subnational governments develop 'bankable' infrastructure projects. PT Sarana Multi Infrastruktur in Indonesia, for example, provides an advisory capability that can help subnational governments prepare infrastructure projects for financing. At an international level, the Global Infrastructure Facility and the Public-Private Infrastructure Advisory Facility's (PPIAF) Sub-National Technical Assistance Program can provide this type of support to subnational governments.

\section{Enhancing coordination and cooperation among and across levels of government}

\section{Vertical and horizontal coordination mechanisms - among and across levels of governments - are essential to support subnational governments to undertake infrastructure investments given that many infrastructure responsibilities are shared among levels of government and across jurisdictions.}

Vertical coordination is needed as infrastructure investment is a shared competency among levels of government. Vertical coordination helps to identify and prioritise investment opportunities and bottlenecks, strategically coordinate investments, and ensure that adequate resources and capacity are in place to undertake investments. Addressing the multi-dimensional and global challenges of climate change, urbanisation, and demographic pressures, for example, requires partnerships that align policy objectives and investments at all levels. While policymakers often recognise the advantages of vertical coordination, it can be difficult to put into practice (OECD, 2019[2]]).

Vertical coordination can be achieved through dialogue and by ensuring the coherence of infrastructure investment strategies at all levels. A long-term infrastructure plan at the national level can be very useful for coordination of investments. It outlines clear priorities and project pipelines for subnational governments and private investors, which in turn can channel public and private resources towards key infrastructure investments at all levels (OECD, 2020[16]). Using co-financing mechanisms, including formalised agreements, contracts, matching funds, and city deals, are another approach to coordinating infrastructure investment among government levels. These are used in many countries, including the United Kingdom, the Netherlands and France (Box 4.1). According to a survey conducted in 2018 among countries that 
adhered to the OECD Recommendation on Effective Public Investment across Levels of Government, 74\% of countries stated that they have formalised agreements such as contracts and partnerships to support public investment (OECD, 2019[2]).

\section{Box 4.1. City deals and contracts in the United Kingdom, the Netherlands and France}

\section{City Deals (the United Kingdom)}

In the United Kingdom (UK), city deals are agreements between government and a city that give the city control to: take charge and responsibility of decisions that affect their area;, do what they think is best to help businesses grow; create economic growth; and decide how public money should be spent. These deals allow a degree of "tailored" devolution of responsibility to cities. The UK City Deals require horizontal (across department) and vertical (between the centre and the cities) co-ordination and local capacity. The UK City Deals are focused on aligning investments by different institutions and the recentring local governments as key agents of urban planning.

\section{Dutch City Deals (the Netherlands)}

In the Netherlands, city deals are agreements signed between central and subnational authorities and stakeholders as part of the "Dutch Urban Agenda (Agenda Stat)". The first city deal was signed for the development of a roadmap for the 'next economy', the second for climate adaptation and others will follow relating to sustainable energy, healthy cities and clean technology. The Climate Adaptation City Deal was signed in 2016 between the Ministry of Infrastructure and the Environment, three regional water authorities, five cities (The Hague, Dordrecht, Gouda, Rotterdam and Zwolle) and seven other partners (research centres and companies).

\section{Contrats de relance et de Transition écologique (France)}

To support the economic recovery from COVID-19 in France and the ecological transition, the French government has launched Contrats de relance et de Transition écologique. These contract are created between local authorities and the national government in order to accelerate the recovery and support ecological, demographic, digital and economic transitions in regions. The six-year contracts can support local authorities to integrate ecological transition into their priorities, in line with the national low-carbon strategy and the national plan for adaption to climate change.

Source: (OECD, 2017[115]; Agence National de la Cohesion de Territoires, $\left.2021_{[181]}\right)$

Horizontal coordination is required so that investment needs are undertaken at the right scale and avoid fragmentation as infrastructure needs and projects often span jurisdictional boundaries. Fragmentation might occur where similar investments are undertaken by neighbouring jurisdictions, unnecessarily duplicating investment. Infrastructure investment coordination and cooperation are difficult, even when actors recognise the need for it. It can be hampered by transaction costs, competitive pressures, resource constraints, differing priorities and fears that the distribution of costs or benefits from co-operation will be one-sided (OECD, 2019[2]).

Jurisdictions can coordinate, cooperate or collaborate when investing to improve public outcomes. Coordination, cooperation and collaboration build on each other, where coordination is the basis, and can grow into collaboration (OECD, 2005[182]). Coordination refers to joint or shared information flows among organisations. Cooperation implies an architecture in the relationship between organisations and a joint intent on the part of organisations. Collaboration implies both joint action and a structured relationship among organisations.

Adopting effective mechanisms for horizontal cooperation helps to bridge information, financing, and capacity gaps of subnational governments (OECD, 2019[2] $)$. In particular, inter-municipal cooperation 
allows local governments to invest at the right scale, reduce fragmentation and duplication of investment, take advantage of spill overs and enjoy more resources for their investment projects (OECD, 2019[2]). It can be particularly beneficial for urban and metropolitan areas to support investment at the right scale, instead of undertaking fragmented investment projects. Nevertheless, inter-municipal cooperation for subnational infrastructure investment is a challenge for local governments in many countries. In the EU, less than $40 \%$ of municipalities coordinated with peers for the planning of infrastructure projects (EIB, $\left.2021_{[29]}\right)$.

Three examples of subnational cooperation to undertake joint infrastructure projects are in Brazil, the Netherlands and France (Box 4.2).

\section{Box 4.2. Inter-municipal cooperation for joint infrastructure projects in Brazil, the Netherlands and France}

In Brazil, the Foz do Rio Itajaí Region, comprised of 11 municipalities and located in the state of Santa Catarina, is planning a network of five Bus Rapid Transit (BRT) corridors and six priority bus lanes as part of the region's integrated mobility strategic plan. The municipalities do not currently have a quality public transport system, with $80 \%$ of trips currently undertaken with private vehicles. The project is expected to reduce congestion and improve air quality by increasing the share of trips made by public transport. The number of trips is expected to rise from $10 \%$ up to $45 \%$ by 2045 .

In the Netherlands, the Hague Metropolitan Area (MRDH) brings together 23 municipalities for a sustainable region with clean, quiet, and energy-efficient transport. The current package contains a total of 26 measures, and each is carried out by an average of seven municipalities. The communities take between 3 and 25 measures aimed at reducing $\mathrm{CO}_{2}$ emissions. The MRDH picks up 14 measures based on its core tasks and supplements them with 2 new measures. A number of measures are being taken by a larger group municipalities, such as the Metropolitan cycle routes measure (20 municipalities) and the expansion of charging infrastructure (18 municipalities) (OECD, 2021 [10]).

In France, inter-municipal cooperation bodies with own-source taxes (établissements de cooperation intercommmunale à fiscalité propre - EPCl) are playing an increasing role as local public investors. While in 1993, their investment expenditure amounted to $8 \%$ of municipal investment, they now account for $25 \%$. The $1254 \mathrm{EPCl}$ (grouping all 35000 French municipalities) includes 21 métropoles (including the three largest metropolitan areas, Paris, Lyon, and Aix-Marseille-Provence) that carry a growing number of major infrastructure projects at the metropolitan scale.

Source: the Netherlands (OECD, 2021 [10]

\section{Establishing enabling regulatory and legal frameworks}

\section{Regulatory and legal frameworks support - or permit - subnational governments to use funding sources, access external financing and adopt investment approaches.}

Some countries do not have the regulatory and legal preconditions for subnational governments to access external financing, and use specific funding and financing instruments. The intergovernmental fiscal framework (highlighted earlier in this chapter) defines the basic funding instruments available for subnational governments. For instance, subnational governments that want to adopt environmental taxes, need to have the autonomy and authority to create new taxes. In the case of land value capture mechanisms, subnational governments need to have specific regulatory and legal frameworks that allow for land taxation, fee mechanisms and systems for the transfer of land ownership. The use of financing is also subject to national regulations and legal frameworks on subnational borrowing. For example, in some 
countries subnational governments are legally not allowed to borrow from private capital markets, or face multiple constraints (e.g. no debt in foreign currencies, golden rules, ceilings for the debt level, etc.). In some cases, subnational borrowing can also be subject to approval by the national government.

Regulations and legal frameworks are also required to support the use of different investment approaches, including supporting cooperation between municipalities and PPPs. Some countries have enacted regulation to encourage inter-municipal cooperation for infrastructure investment; while in other cases, forming a formal inter-municipal cooperation body for infrastructure delivery is not supported by law. In the case of PPPs, flexible and inclusive statutory frameworks that fosters private sector participation, as well as clear and transparent PPP proposal review requirements, can help subnational governments use PPPs based on value for money, affordability, and other factors. In Colombia, a regulatory framework was established for all PPP projects at the subnational level, including regulation concerning indebtedness levels, funding sources and alignment with subnational development objectives. A PPP Registry (Registro Único de Asociación Público Privada) was also established to register PPP priority projects at all levels to support transparency (Government of Colombia, 2012[183]). The Commonwealth of Virginia in the United States has adopted an approach to ensure the coherence of legal and regulatory frameworks for PPPs among levels of government (Box 4.3).

\section{Box 4.3. Public-private partnership legal frameworks in the Commonwealth of Virginia}

The Commonwealth of Virginia in the United States adapted its public private partnership (PPP) regulations to produce a flexible PPP programme. From the outset, it adopted a state-wide, programmatic approach, without geographic or political restrictions. As the state's statutory framework developed, this programme extended to a nearly unlimited range of qualifying proposal types, facility types, partner types, delivery approaches, and financing options. As a result, private parties encounter few limitations.

Virginia's PPP projects face limited legislative intervention. State law does not require legislative approval prior to facility procurement, relying instead on responsible public entities for project review, approvals, and management. To address the potential accountability deficit, Virginia established the Transportation Public-Private Partnership Advisory Committee, charged with assessing whether proposed projects serve the public interest.

In addition to its inclusive statutes, implementation guidelines were developed to help potential and active partners understand and navigate the state's PPP procurement procedures.

Source: (OECD, 2018[163]) 


\section{References}

abundance (2021), Warrington 2025 Council Green Bonds, https://www.abundanceinvestment.com/our-impact/investments/warrington-2025 (accessed on 11 August 2021).

ACCC (2021), Privatise for efficiency, or not at all, https://www.accc.gov.au/mediarelease/privatise-for-efficiency-or-not-at-all (accessed on 18 August 2021).

AFL (2020), "Business Review and Sustainable Development Report 2020".

Agence National de la Cohesion de Territoires (2021), Contrat de relance et de Transition écologique, https://agence-cohesion-territoires.gouv.fr/crte (accessed on 13 September 2021).

Allain-Dupré, D., C. Hulbert and C. Vammalle (2012), Public Investment at Central and Subnational Levels: An Adjustment Variable for OECD Countries in the Present Context of Austerity?, https://search.oecd.org/cfe/regionaldevelopment/Effective-Public-InvestmentOverview-Paper.pdf (accessed on 13 September 2021).

Allain-Dupré, D., C. Hulbert and M. Vincent (2017), "Subnational Infrastructure Investment in OECD Countries: Trends and Key Governance Levers", OECD Regional Development Working Papers, No. 2017/05, OECD Publishing, Paris, https://dx.doi.org/10.1787/e9077df7en.

Allen, R. et al. (2020), "Integrated Infrastructure Planning and Budgeting", in Well Spent: How Strong Infrastructure Governance Can End Waste in Public Investment, IMF, https://blogpfm.imf.org/pfmblog/2020/09/-integrated-infrastructure-planning-and-budgeting-.html (accessed on 1 December 2021).

Altman, R., A. Klein and A. Krueger (2015), Financing U.S. Transportation Infrastructure in the 21st Century, Brookings, The Hamilton Project.

Andersson, L. (2014), "Local Government Finance in Europe-Trends to Create Local Government Funding Agencies".

ASCE (2021), Washington, D.C. Civil Engineers Give the District's Infrastructure a "C" Grade | ASCE's 2021 Infrastructure Report Card, American Society of Civil Engineers, https://infrastructurereportcard.org/washington-d-c-civil-engineers-give-the-districtsinfrastructure-a-c-grade/ (accessed on 20 August 2021).

Asian Development Bank (2021), 100 Climate Actions from Cities in Asia and the Pacific, https://www.adb.org/sites/default/files/publication/705086/100-climate-actions-cities-asiapacific.pdf.

Asian Development Bank (2020), "Reforms, opportunities, and challenges for State-Owned Enterprises”, https://www.adb.org/sites/default/files/publication/618761/reforms-opportunitieschallenges-state-owned-enterprises.pdf (accessed on 17 August 2021).

Australian Government (2019), Review of the National Partnership Agreement on Asset Recycling, The Treasury, https://treasury.gov.au/publication/p2019-t349382 (accessed on 24 August 2021). 
BBVA (2020), MAPFRE, the Autonomous Community of Madrid and BBVA issue Spain's first social bond against the coronavirus, https://www.bbva.com/en/mapfre-the-autonomouscommunity-of-madrid-and-bbva-issue-spains-first-social-bond-against-the-coronavirus/ (accessed on 30 August 2021).

Berlin, A., X. Zhang and Y. Chen (2020), "Global EV Outlook 2020: Case Study: Electric buses in Shenzhen, China", International Energy Agency, https://iea.blob.core.windows.net/assets/db408b53-276c-47d6-8b05-52e53b1208e1/e-buscase-study-Shenzhen.pdf (accessed on 9 August 2021).

Brookings (2021), Four takeaways on new guidance for state and local fiscal relief under the American Rescue Plan, https://www.brookings.edu/blog/the-avenue/2021/05/13/fourtakeaways-on-new-guidance-for-state-and-local-fiscal-relief-under-the-american-rescue-plan/ (accessed on 1 July 2021).

Brookings (2021), The American Rescue Plan is the broadband down payment the country needs, The Brookings Institution, https://www.brookings.edu/research/the-american-rescue-plan-isthe-broadband-down-payment-the-country-needs/ (accessed on 27 August 2021).

Brookings (2017), From bridges to education: best bets for public investment, https://www.brookings.edu/wpcontent/uploads/2017/01/200170109 public investment transcript.pdf (accessed on 18 August 2021).

C40 Cities (2015), Milan's Area C reduces traffic pollution and transforms the city center, https://www.c40.org/case studies/milan-s-area-c-reduces-traffic-pollution-and-transforms-thecity-center (accessed on 25 August 2021).

Caramazana, D. (2020), The experience of Guatemala City on municipal asset management, UNDP Cities and Urbanization Secretariat, https://city2city.network/experience-guatemala-citymunicipal-asset-management (accessed on 25 August 2021).

CBO (2018), Public Spending on Transportation and Water Infrastructure, 1956 to 2017, http://www.cbo.gov/publication/49910. (accessed on 13 August 2021).

Christensen, L. and C. Greve (2018), "Choosing State Owned Enterprises over Public-Private Partnerships for infrastructure governance: Explaining institutional change with evidence from Denmark's transport sector", Public Management Review, Vol. 18/2, http://www.ipmr.net (accessed on 17 August 2021).

City of Cambridge (2018), City Announces Second Minibond Issuance, Invites Residents to Directly Invest in Cambridge - City of Cambridge, MA, https://www.cambridgema.gov/news/2018/01/cambridgeannouncessecondminibondissuance (accessed on 10 August 2021).

City of Toronto (2021), Education Development Charges, https://www.toronto.ca/citygovernment/budget-finances/city-finance/development-charges/education-developmentcharges/ (accessed on 22 July 2021).

City of Yokohama (2021), Overview of Yokohama Green Tax, https://www.city.yokohama.lg.jp.e.sj.hp.transer.com/kurashi/koseki-zeihoken/zeikin/midorizei/midorizei.html (accessed on 25 August 2021).

Congressional Research Service (2020), State Broadband Initiatives: Selected State and Local 
Approaches as Potential Models for Federal Initiatives to Address the Digital Divide, https://crsreports.congress.gov (accessed on 25 August 2021).

CSG (2021), Anaylsis of the American Rescue Plan: Infrastructure, The Council of State

Governments, https://web.csg.org/covid19/wp-content/uploads/sites/10/2021/04/Analysis-ofthe-American-Rescue-Plan-Infrastructure.pdf (accessed on 1 July 2021).

Dag Detter and Stefan Fölster (2018), The Public Wealth of Cities, La Fabrique de la Cité, https://www.lafabriquedelacite.com/en/publications/the-public-wealth-of-cities/ (accessed on 14 June 2021).

Department of Transport (2021), Victoria's managed motorways go global, https://transport.vic.gov.au/about/transport-news/news-archive/victorias-managed-motorwaysgoglobal? cf chl captcha tk =xXFehPMPM58wmEVd.W 5oPw26NMxdycDC5055VzdWcA1638289578-0-gaNycGzNCFE (accessed on 1 December 2021).

Detter, D. and S. Fölster (2015), The Public Wealth of Nations, Palgrave Macmillan UK, London, http://dx.doi.org/10.1057/9781137519863.

Dorothee Allain-Dupre, Isabelle Chatry and Louise Phung (2020), "OECD Fiscal Federalism Studies Local Public Finance and Capacity Building in Asia ISSUES AND CHALLENGES: Chapter 4. Subnational capacity building: An international perspective of the Asia Pacific region".

EIB (2021), Guarantees, https://www.eib.org/en/products/guarantees/index.htm (accessed on 18 August 2021).

EIB (2021), Investment Report 2020/2021: Building a smart and green Europe in the COVID-19 era, European Investment Bank, https://www.eib.org/en/publications/investment-report-2020 (accessed on 14 June 2021).

EIB (2021), The State of Local Infrastructure Investment in Europe - EIB Municipalities Survey 2020, European Investment Bank, https://www.eib.org/attachments/efs/eibis 2020 municipality en.pdf.

EIB (2018), Greece: EIB confirms EUR 55 million backing for Athens urban investment during Mayor's visit, https://www.eib.org/en/press/all/2018-159-eib-confirms-eur-55-million-backingfor-athens-urban-investment-during-mayors-visit.htm (accessed on 30 August 2021).

Ely, T. and C. Martell (2016), "Costs of Raising (Social) Capital Through Mini-Bonds", Municipal Finance Journal, pp. 23-43, https://www.civicresearchinstitute.com/online/PDF/MFJ-3703-02Mini-Bonds.pdf (accessed on 10 August 2021).

European Commission (2021), European Regional Development Fund, https://ec.europa.eu/regional policy/en/funding/erdf/ (accessed on 18 August 2021).

European Commission (2013), Milan: lessons in congestion charging / Eco-innovation Action Plan, https://ec.europa.eu/environment/ecoap/about-eco-innovation/goodpractices/italy/20130708 milan-lessons-in-congestion-charging en (accessed on 15 August 2021).

European Commission (n.d.), European Regional Development Fund, https://ec.europa.eu/regional policy/en/funding/erdf/ (accessed on 29 August 2012). 
Eurostat (2016), A guide to the statistical treatment of PPPs, https://op.europa.eu/en/publicationdetail/-/publication/ea7c19f7-9146-11e8-8bc1-01aa75ed71a1/language-en (accessed on 17 August 2021).

Federal Ministry of the Interior, Building and Community (2021), 28 model projects Smart Cities selected for the third season, https://www.bmi.bund.de/SharedDocs/kurzmeldungen/DE/2021/07/smartcity.html;jsessionid=CA96CF4ABFD9914DFE77B8845702B9C1.1 cid287 (accessed on 15 August 2021).

Financial Express (2020), Transferable development rights: A win-win deal, https://www.financialexpress.com/opinion/transferable-development-rights-a-win-windeal/2129753/ (accessed on 22 July 2021).

FMDV (2015), "Creating the Local Financing Framework for Sustainable Development Goals: The Potential Catalytic Role of Subnational Pooled Financing Mechanisms", https://fmdv.net/admin/Images/Publications/41/FMDV Policy\%20Paper \%20SPFM\%20ENG.p df (accessed on 29 August 2021).

GIIN (2020), Annual Impact Investor Survey 2020, Global Impact Investing Network, http://www.thegiin.org/. (accessed on 18 August 2021).

GIZ (2012), Financing Local Infrastructure - Linking Local Governments and Financial Markets, Deutsche Gesellschaft für Internationale Zusammenarbeit, http://admin.riafco.org//mages/Ressources/Pulication/49/Financing\%20local\%20Infrastructure \%20Finance\%20final\%20-\%20GIZ\%202012.pdf.

Global Infrastructure Hub and CEPA (2019), Guidance Note on National Infrastructure Banks and Similar Financing Facilities, https://www.gihub.org/nibs/ (accessed on 11 August 2021).

Goldman Sachs (2016), FACT SHEET: DC Water Environmental Impact Bond.

Government of Canada (2015), Capital Facilities and Maintenance Program, https://www.sacisc.gc.ca/eng/1100100016395/1533641696528 (accessed on 23 August 2021).

Government of Colombia (2012), Law 1508 of 2012 National Level, https://www.alcaldiabogota.gov.co/sisjur/normas/Norma1.jsp?i=45329 (accessed on 10 September 2021).

Government of India (2021), Smart Cities : Ministry of Housing and Urban Affairs, Goverment of India, http://mohua.gov.in/cms/smart-cities.php (accessed on 15 August 2021).

Government of South Australia (2021), Electric Vehicle Road User Charge consultation to begin / Premier of South Australia, https://www.premier.sa.gov.au/news/media-releases/news/electricvehicle-road-user-charge-consultation-to-begin (accessed on 23 August 2021).

Haas, A. and S. Kriticos (2019), Considerations for land value capture reform in the Greater Amman Municipality, International Growth Centre, The London School of Economics and Political Science, http://eprints.Ise.ac.uk/id/eprint/103072.

Hans, A. (2020), Transferable development rights: A robust policy tool to address India's urban infrastructure voids, World Bank Blogs, https://blogs.worldbank.org/ppps/transferabledevelopment-rights-robust-policy-tool-address-indias-urban-infrastructure-voids. 
Hansson, A. (2017), "Promoting planning for housing development: What can Sweden learn from Germany?", Land Use Policy, Vol. 64, pp. 470-478, http://dx.doi.org/10.1016/j.landusepol.2017.03.012.

HM Treasury (2021), UK Infrastructure Bank Policy Design, https://assets.publishing.service.gov.uk/government/uploads/system/uploads/attachment data/ file/966131/UKIB Policy Design.pdf (accessed on 10 August 2021).

HM Treasury (2020), National Infrastructure Strategy, https://www.gov.uk/government/publications/national-infrastructure-strategy (accessed on 17 August 2021).

HM Treasury (2019), "Infrastructure Finance Review: consultation", https://assets.publishing.service.gov.uk/government/uploads/system/uploads/attachment data/ file/785546/infrastructure finance review consultation web version.pdf (accessed on 18 August 2021).

HM Treasury (2018), Budget 2018, https://www.gov.uk/government/publications/budget-2018documents (accessed on 17 August 2021).

Hussain, F. (2020), Green loans: Financing the transition to a low-carbon economy, World Bank Blogs, https://blogs.worldbank.org/climatechange/green-loans-financing-transition-low-carboneconomy (accessed on 16 August 2021).

ICAP (2021), International Carbon Action Partnership (ICAP) - Emissions Trading Worldwide Status report, https://icapcarbonaction.com/.

ICMA (2021), Green Bond Principles, https://www.icmagroup.org/assets/documents/Sustainablefinance/2021-updates/Green-Bond-Principles-June-2021-140621.pdf (accessed on 17 August 2021).

ICMA (2021), Social Bond Principles, Voluntary Process Guidelines for Issuing Social Bonds, International Capital Market Association.

IFC (2021), IFC's Green Loan to Boost Climate Finance and Drive Sustainability in Brazil, https://pressroom.ifc.org/all/pages/PressDetail.aspx?ID=26349 (accessed on 19 August 2021).

IISD (2020), Financing A Sustainable Recovery: U.K.'s First Local Government Green Bond, International Institute for Sustainable Development, https://www.iisd.org/sustainablerecovery/news/financing-a-sustainable-recovery-uks-first-local-government-green-bond/.

IMF (2020), FISCAL MONITOR: Policies to support people during the COVID-19 Pandemic, https://www.imf.org/en/Publications/FM/lssues/2020/04/17/Fiscal-Monitor-April-2020-Policiesto-Support-People-During-the-COVID-19-Pandemic-49278 (accessed on 12 August 2021).

Indian Ministry of Finance (2020), Cabinet approves Continuation and Revamping of the Scheme for Financial Support to Public Private Partnerships in Infrastructure Viability Gap Funding VGF Scheme, https://pib.gov.in/PressReleasePage.aspx?PRID=1671914 (accessed on 15 August 2021).

Infrastructure Canada (2021), Climate Lens - General Guidance, https://www.infrastructure.gc.ca/pub/other-autre/cl-occ-eng.html (accessed on 15 August 2021). 
Inter-American Development Bank (2017), The Potential of Land Value Capture for financing urban projects: methodological considerations and case studies, https://publications.iadb.org/publications/english/document/The-Potential-of-Land-ValueCapture-for-Financing-Urban-Projects-Methodological-Considerations-and-Case-Studies.pdf.

Istituto Affari Internazionali (2021), Reviving and Reorienting Growth after the Pandemic: The Role [6] of Local Infrastructure Investments, https://www.iai.it/sites/default/files/9788893681858.pdf.

Italian G20 Presidency (2021), "G20 Policy Agenda on Infrastructure Maintenance", https://www.g20.org/wp-content/uploads/2021/07/G20-Policy-Agenda-on-InfrastructureMaintenance.pdf (accessed on 30 August 2021).

ITF (2015), The Regulatory Asset Base Model and the Project Finance Model: A comparative analysis, International Transport Forum, http://www.internationaltransportforum.org/itrc/DiscussionPapers/itrcpapers.html (accessed on 15 August 2021).

JFM (2020), About JFM, https://www.jfm.go.jp/en/about/ (accessed on 16 August 2021).

Ju Kim, C. and Z. Ali (2017), "Efficient Management of State-Owned Enterprises: Challenges and Opportunities".

Katz, B. and L. Noring (2017), The Copenhagen City and Port Development Corporation: A Model for Regenerating Cities, Centennial Scholar Initiative at Brookings.

Kim, J. (2016), Handbook on Urban Infrastructure Finance, New Cities Foundation, http://bit.ly/NCFUrbanFinance.

Kim, J. and S. Dougherty (eds.) (2020), Local Public Finance and Capacity Building in Asia: Issues [47] and Challenges, OECD Fiscal Federalism Studies, OECD Publishing, Paris, https://dx.doi.org/10.1787/a944b17e-en.

Lewis, B. and P. Smoke (2017), "Intergovernmental Fiscal Transfers and Local Incentives and Responses: The Case of Indonesia", Fiscal Studies, Vol. 38/1, http://dx.doi.org/10.1111/1475$\underline{5890.12080 .}$.

Lincoln Institute of Land Policy (2018), Land value capture: Tools to finance our urban future, http://archive.citiscope.org/story/2014/how-sao-paulo-uses- (accessed on 24 August 2021).

Loan Market Association (2018), Green Loan Principles Supporting environmentally sustainable economic activity, https://www.Ima.eu.com/application/files/9115/4452/5458/741 LM Green Loan Principles Bo oklet V8.pdf (accessed on 16 August 2021).

Luis Acero, J. and A. Nunez (2014), Creating the First Latin American Tax Increment Financing (TIF) Instrument, Anual World Bank Conference on Land and Poverty 2014.

Mahendra, A. et al. (2020), "Urban Land Value Capture in São Paulo, Addis Ababa, and Hyderabad: Differing Interpretations, Equity Impacts, and Enabling Conditions", Lincoln Institute of Land Policy, http://www.wri.org/publication/ (accessed on 19 August 2021).

McKinsey (2017), Improving infrastructure outcomes through better capital allocation, https://www.mckinsey.com/business-functions/operations/our-insights/improving-infrastructureoutcomes-through-better-capital-allocation (accessed on 1 December 2021). 
McKinsey (2016), The 'Rail plus Property' model: Hong Kong's successful self-financing formula / McKinsey, https://www.mckinsey.com/business-functions/operations/our-insights/the-rail-plusproperty-model (accessed on 17 August 2021).

Merk, O. et al. (2012), "Financing Green Urban Infrastructure", OECD Regional Development Working Papers, No. 2012/10, OECD Publishing, Paris, https://dx.doi.org/10.1787/5k92p0c6j6r0-en.

Merriman, D. (2018), Improving Tax Increment Financing (TIF) for Economic Development, Lincoln Institute of Land Policy, https://www.lincolninst.edu/sites/default/files/pubfiles/improving-tax-increment-financing-full.pdf (accessed on 19 August 2021).

Metropolitan Regional Government of Santiago (n.d.), Fondo Nacional de Desarrollo Regional (FNDR), https://www.gobiernosantiago.cl/fndr/ (accessed on 27 August 2021).

Ministry of Internal Affairs and Communications of Japan (2018), Local Government Bond System and Market in Japan, http://www.chihousai.or.jp/english/07/pdf/2018 mic.pdf.

Minstry of Housing, Communities and Local Government, UK (2018), Land Value Capture - Tenth Report of Session 2017-19, https://publications.parliament.uk/pa/cm201719/cmselect/cmcomloc/766/766.pdf.

National Infrastructure Commission (2018), Recommendations Archive, https://nic.org.uk/studiesreports/recommendations/ (accessed on 16 August 2021).

National Treasury, Republic of South Africa (2020), Part 3: Frameworks for Conditional Grants to Municipalities, http://www.treasury.gov.za/documents/national\%20budget/2020/Part\%203\%20\%20Local\%20government\%20conditional\%20grant\%20frameworks.pdf (accessed on 20 August 2021).

NBN Co (2021), nbn ${ }^{\mathrm{TM}}$ Regional Co-Investment Fund Guidelines, https://www.nbnco.com.au/content/dam/nbn/documents/about-nbn/reports/nbn-rcifguidelines.pdf (accessed on 1 July 2021).

NYC Planning (2015), A Survey of Transferable Development Rights Mechanisms in New York City, https://www1.nyc.gov/site/planning/plans/transferable-development-rights/transferabledevelopment-rights.page (accessed on 19 August 2021).

OECD (2021), Building a Global Compendium on Land Value Capture, https://www.oecd.org/cfe/cities/Flyer-Land-Capture-a4.pdf (accessed on 19 August 2021).

OECD (2021), Building Resilience: New Strategies for Strengthening Infrastructure Resilience and Maintenance, OECD Publishing, https://www.oecd.org/gov/infrastructuregovernance/resilience-maintenance/Building-Infrastructure-Resilience-OECD-Report.pdf.

OECD (2021), COVID-19 and the low-carbon transition: Impacts and possible policy responses, OECD Publishing, https://www.oecd.org/coronavirus/policy-responses/covid-19-and-the-lowcarbon-transition-impacts-and-possible-policy-responses-749738fc/.

OECD (2021), Decentralisation and Regionalisation in Bulgaria: Towards Balanced Regional Development, OECD Multi-level Governance Studies, OECD Publishing, Paris, https://dx.doi.org/10.1787/b5ab8109-en. 
OECD (2021), Delivering Quality Education and Health Care to All: Preparing Regions for Demographic Change, OECD Rural Studies, OECD Publishing, Paris, https://dx.doi.org/10.1787/83025c02-en.

OECD (2021), Implementation Handbook for Quality Infrastructure Investment, Chapter 4, Subnational Governance and Investment in Infrastructure, OECD Publishing, https://www.oecd.org/finance/oecd-implementation-handbook-for-quality-infrastructureinvestment.htm.

OECD (2021), Implications of Remote Working Adoption on Place Based Policies: A Focus on G7 Countries, OECD Publishing, Paris, https://dx.doi.org/10.1787/b12f6b85-en.

OECD (2021), OECD Regional Outlook 2021: Addressing COVID-19 and Moving to Net Zero Greenhouse Gas Emissions, OECD Publishing, Paris, https://doi.org/10.1787/17017efe-en., https://doi.org/10.1787/17017efe-en.

OECD (2021), OECD Regional Recovery Platform, https://www.oecd.org/regional/recoveryplatform.htm.

OECD (2021), Subnational governments in OECD countries: Key data, OECD Publishing, https://www.oecd.org/regional/multi-level-governance/OECD SNG Nuancier 2021.pdf.

OECD (2021), The territorial impact of COVID-19: Managing the crisis and recovery across levels of government, OECD Publishing, https://www.oecd.org/coronavirus/policy-responses/theterritorial-impact-of-covid-19-managing-the-crisis-and-recovery-across-levels-of-governmenta2c6abaf/.

OECD (2020), G20/OECD Report on the Collaboration with Institutional Investors and Asset Managers on Infrastructure: Investor Proposals and the Way Forward, https://www.oecd.org/daf/fin/private-pensions/Collaboration-with-Institutional-Investors-andAsset-Managers-on-Infrastructure.pdf (accessed on 20 August 2021).

OECD (2020), Multilateral Development Finance 2020, OECD Publishing, Paris, https://dx.doi.org/10.1787/e61fdf00-en.

OECD (2020), OECD Compendium of Good Practices for Quality Infrastructure Investment, OECD Publishing, https://www.oecd.org/finance/oecd-compendium-of-policy-good-practices-forquality-infrastructure-investment.htm.

OECD (2020), OECD Regions and Cities at a Glance 2020, OECD Publishing, Paris, https://dx.doi.org/10.1787/959d5ba0-en.

OECD (2020), Recommendation of the Council on the Governance of Infrastructure, https://legalinstruments.oecd.org/en/instruments/OECD-LEGAL-0460 (accessed on 18 August 2021).

OECD (2020), Revenue Statistics 2020, OECD Publishing, Paris, https://dx.doi.org/10.1787/8625f8e5-en.

OECD (2019), A Policy Maker's Guide to Privatisation, Corporate Governance, OECD Publishing, Paris, https://dx.doi.org/10.1787/ea4eff68-en.

OECD (2019), Budgeting and Public Expenditures in OECD Countries 2019, OECD Publishing, Paris, https://dx.doi.org/10.1787/9789264307957-en. 
OECD (2019), Effective Public Investment across Levels of Government: Implementing the OECD

Principles, OECD Publishing, https://www.oecd.org/effective-public-investmenttoolkit/OECD Principles For Action 2019 FINAL.pdf.

OECD (2019), "Financing climate objectives in cities and regions to deliver sustainable and inclusive growth", OECD Environment Policy Papers, No. 17, OECD Publishing, Paris, https://dx.doi.org/10.1787/ee3ce00b-en.

OECD (2019), Making Decentralisation Work: A Handbook for Policy-Makers, OECD Multi-level Governance Studies, OECD Publishing, Paris, https://dx.doi.org/10.1787/g2g9faa7-en.

OECD (2019), OECD Regional Outlook 2019: Leveraging Megatrends for Cities and Rural Areas, OECD Publishing, Paris, https://dx.doi.org/10.1787/9789264312838-en.

OECD (2019), OECD Statistics on Private Philanthropy for Development, OECD Publishing.

OECD (2018), "Ownership and Governance of State-Owned Enterprises A Compendium of National Practices".

OECD (2018), "Privatisation and the Broadening of Ownership of State-Owned Enterprises".

OECD (2018), Subnational Public-Private Partnerships: Meeting Infrastructure Challenges, OECD Multi-level Governance Studies, OECD Publishing, Paris, https://dx.doi.org/10.1787/9789264304864-en.

OECD (2017), Conditionality in practice: Emerging lessons for public investment EC-OECD Seminar Series on Designing better economic development policies for regions and cities, OECD Publishing Paris.

OECD (2017), Investing in Climate, Investing in Growth, OECD Publishing, Paris, https://dx.doi.org/10.1787/9789264273528-en.

OECD (2017), Investing in Climate, Investing in Growth, OECD Publishing, Paris, https://dx.doi.org/10.1787/9789264273528-en.

OECD (2017), Making Decentralisation Work in Chile: Towards Stronger Municipalities, OECD Multi-level Governance Studies, OECD Publishing, Paris, https://dx.doi.org/10.1787/9789264279049-en.

OECD (2017), The Governance of Land Use in OECD Countries: Policy Analysis and Recommendations, OECD Publishing, Paris, https://dx.doi.org/10.1787/9789264268609-en.

OECD (2016), OECD Territorial Reviews: Japan 2016, OECD Territorial Reviews, OECD Publishing, Paris, https://dx.doi.org/10.1787/9789264250543-en.

OECD (2015), Infrastructure Financing Instruments and Incentives, OECD Publishing Paris.

OECD (2015), OECD Guidelines on Corporate Governance of State-Owned Enterprises, 2015 Edition, OECD Publishing, Paris, https://dx.doi.org/10.1787/9789264244160-en.

OECD (2014), Recommendation of the OECD Council on Effective Public Investment Across Levels of Government, https://www.oecd.org/effective-public-investmenttoolkit/recommendation-effective-public-investment-across-levels-of-government.htm (accessed on 27 August 2021). 
OECD (2012), "Recommendation of the Council on Principles for Public Governance of PublicPrivate Partnerships", https://www.oecd.org/governance/budgeting/PPP-Recommendation.pdf (accessed on 17 August 2021).

OECD (2005), e-Government for Better Government, OECD e-Government Studies, OECD Publishing, Paris, https://dx.doi.org/10.1787/9789264018341-en.

OECD (Forthcoming), A review of local government finance in Israel: reforming the Arnona system.

OECD/European Commission (2020), Cities in the World: A New Perspective on Urbanisation, OECD Urban Studies, OECD Publishing, Paris, https://dx.doi.org/10.1787/d0efcbda-en.

OECD/UCLG (2019), OECD-UCLG World Observatory on Subnational Government Finance and Investment (SNG-WOFI) Database, https://stats.oecd.org/viewhtml.aspx?datasetcode $=S N G F$ WO\&vh $=0000 \& v f=00 \& \mid \& i l=b l a n k \& l a n$ $\mathrm{q}=\mathrm{en} \& \mathrm{vcq}=1111$.

OECD and ITF (2019), "HIGHLIGHTS Tax Revenue Implications of Decarbonising Road Transport Scenarios for Slovenia", https://www.oecd.org/tax/tax-policy/highlights-tax-revenueimplications-of-decarbonising-road-transport-scenarios-for-slovenia.pdf (accessed on 24 August 2021).

OECD and UCLG (2019), 2019 Report World Observatory on Subnational Government Finance and Investment: Key findings, OECD Paris, https://www.sng-wofi.org/reports/ (accessed on 13 June 2021).

Office for Budget Responsibility (2017), Fiscal risk report, https://obr.uk/frr/fiscal-risk-report-july2017/ (accessed on 17 August 2021).

Ontario Government (2019), Rebuilding Ontario: an infrastructure plan for the people, https://www.ontario.ca/document/rebuilding-ontario-infrastructure-plan-people (accessed on 25 August 2021).

Parliament of Australia (2014), Infrastructure Growth Package-Asset Recycling Fund, https://www.aph.gov.au/About Parliament/Parliamentary Departments/Parliamentary Library/ pubs/rp/BudgetReview201415/InfrastructureGrowth (accessed on 15 August 2021).

Peterson, G. (2002), "Banks or Bonds? Building a Municipal Credit Market".

Premier of Victoria (2021), Ensuring Drivers Pay Their Fair Share To Use Our Roads / Premier of Victoria, https://www.premier.vic.gov.au/ensuring-drivers-pay-their-fair-share-use-our-roads (accessed on 23 August 2021).

Puentes, R. and J. Thompson (2012), "Project on State and Metropolitan Innovation Banking on Infrastructure: Enhancing State Revolving Funds for Transportation".

pwc (2015), State-Owned Enterprises: Catalysts for public value creation?, https://www.pwc.com/gx/en/psrc/publications/assets/pwc-state-owned-enterprise-psrc.pdf (accessed on 13 August 2021).

Queensland Government (2021), 2020-21 COVID Works for Queensland program, https://www.statedevelopment.qld.gov.au/local-government/grants/current-programs/covid-19w4q (accessed on 20 August 2021). 
Region Île-de-France (2021), "Green, social and sustainable bond framework for the Île-de-France Region".

Rioja, F. (2012), What Is the Value of Infrastructure Maintenance? A Survey, Lincoln Institute.

Rozenberg, J. and M. Fay (2019), Beyond the Gap : How Countries Can Afford the Infrastructure They Need while Protecting the Planet, World Bank, https://openknowledge.worldbank.org/handle/10986/31291 (accessed on 20 August 2021).

Salwati, N. and D. Wessel (2021), What are Build America Bonds or direct-pay municipal bonds?, Brookings, https://www.brookings.edu/blog/up-front/2021/08/04/what-are-build-america-bondsor-direct-pay-municipal-bonds/ (accessed on 18 August 2021).

Sandroni, P. (2010), A New Financial Instrument of Value Capture in São Paulo / Lincoln Institute of Land Policy, https://www.lincolninst.edu/publications/conference-papers/new-financialinstrument-value-capture-sao-paulo (accessed on 19 August 2021).

Seoul Solution (2018), Volume Based Waste Fee(VBMF) System for Municipal Solid Waste, https://seoulsolution.kr/en/content/6326 (accessed on 24 August 2021).

Shah, A. (2017), "Development assistance and conditionality: Challenges in design and options for [46 more effective assistance", OECD Seminar Series on Designing better economic development policies for regions and cities, OECD, https://search.oecd.org/cfe/regionaldevelopment/ShahDevelopment-assistance-and-conditionality.pdf (accessed on 28 September 2021).

Spacehive (2021), About Spacehive: A funding platform to make local places better, https://www.spacehive.com/about (accessed on 11 August 2021).

Spahn, P. (2012), Conditioning Intergovernmental Transfers and Modes of Interagency Cooperation for Greater Effectiveness of Multilevel Government in OECD Countries, https://www.oecd.org/cfe/regionaldevelopment/Conditioning-Intergovernmental-Transferspaper.pdf (accessed on 26 August 2021).

State Government of Victoria (2021), About us - Victoria's Big Build, https://bigbuild.vic.gov.au/about (accessed on 12 August 2021).

Takagi, Y. (2014), Local green tax as a driver towards a greentransformation: Lessons from the Yokohamagreen tax, https://www.unescap.org/sites/default/files/RRSOED-Lessons-from-theYokohama-green-tax-by-YusukeTagaki.pdf (accessed on 25 August 2021).

Tideway (2020), Annual Report 2019/20, https://www.tideway.london/media/4491/tideway-annualreport-2019-20.pdf (accessed on 18 August 2021).

TNUIFSL (n.d.), Tamil Nadu Urban Development Fund, http://www.tnuifsl.com/tnudf.asp (accessed on 16 August 2021). 然 
(accessed on 16 August 2021).

U.S. Treasury Department (2011), Build America Bonds Issuance and Savings, https://www.treasury.gov/initiatives/recovery/Documents/BABs\%20Report.pdf (accessed on 18 August 2021).

UCLG (2016), Land readjustment in urban settings, "Kukaku Seiri”.

UK National Audit Office (2018), "PFI and PF2", Report by the Comptroller and Auditor General January 2018, pp. 0-17.

United Nations (2021), Managing Infrastructure Assets for Sustainable Development: A Handbook for Local and National Governments, https://www.un.org/development/desa/financing/document/un-handbook-infrastructure-assetmanagement (accessed on 10 June 2021).

University of Tokyo (2013), Privately owned public spaces: The international perspective, Center for Sustainable Urban Regeneration.

UNOPS (2021), Head of new S3I advisory committee confirmed, https://www.unops.org/newsand-stories/news/head-of-new-s3i-advisory-committee-confirmed (accessed on 17 August 2021).

US DOT (2019), Case Studies: Atlanta BeltLine Tax Allocation District, https://www.fhwa.dot.gov/ipd/value capture/case studies/atlanta beltline tax allocation distri ct.aspx (accessed on 27 August 2021).

Vammalle, C. and I. Bambalaite (2021), "Funding and financing of local government public investment: A framework and application to five OECD countries", OECD Working Papers on Fiscal Federalism, No. 34, OECD Publishing, https://www.oecd.org/newzealand/funding-andfinancing-of-local-government-public-investment-162d8285-en.htm (accessed on 11 August 2021).

Velasco Bernal, V. and M. Almonacid (2021), How can we help Latin American cities finance urban development?, World Bank Blog, https://blogs.worldbank.org/ppps/how-can-we-helplatin-american-cities-finance-urban-development.

VicRoads (2021), ZLEV road-user charge : VicRoads, https://www.vicroads.vic.gov.au/registration/registration-fees/zlev-road-user-charge (accessed on 23 August 2021).

World Bank (2021), Green Urban Financing and Innovation Project, https://projects.worldbank.org/en/projects-operations/document-detail/P158124?type=projects (accessed on 30 August 2021).

World Bank (2021), Municipal Public-Private Partnership Framework, https://ppp.worldbank.org/public-private-partnership/subnational-and-municipal/municipalpublic-private-partnership-framework.

World Bank (2017), WHO SPONSORS INFRASTRUCTURE PROJECTS? Disentangling public and private contributions, https://blogs.worldbank.org/ppps/who-finances-infrastructure-reallydisentangling-public-and-private-contributions (accessed on 12 August 2021). 
Raise Their Credit Ratings, http://www.worldbank.org/en/news/feature/2013/10/24/financingsustainable-cities-africacreditworthy.

World Bank (2013), Inventory and valuation of public land assets in Ahmedabad, India, https://urban-regeneration.worldbank.org/node/37 (accessed on 24 August 2021).

World Bank (n.d.), Land Value Cpatire (LVC), https://www.gfdrr.org/sites/default/files/D2 3 MattHunt LVC Bangkok (MH).original.15313679 92.pdf.

World Bank Group (2021), Well-maintained: Economic Benefits from More Reliable \& Resilient Infrastructure, https://library.pppknowledgelab.org/documents/6031/download (accessed on 6 September 2021).

World Bank Group (2015), Urban Regeneration Decision Tool, https://urbanregeneration.worldbank.org/survey.

World Bank Group (n.d.), Land Value Capture, https://www.gfdrr.org/sites/default/files/publication/Land\%20Value\%20Capture.pdf.

World Bank Group et al. (2017), Public-Private Partnerships: Reference Guide Version 3, https://openknowledge.worldbank.org/handle/10986/29052 (accessed on 13 August 2021).

World Bank Group and Inter-American Development Bank (2019), Global Review of Public Infrastructure Funds VOLUME II. CASE STUDIES, https://ppiaf.org/documents/5983 (accessed on 24 August 2021).

WWF (2021), WWF welcomes the issue of first Russia's regional green bonds, https://wwf.ru/en/resources/news/zelenaya-ekonomika/wwf-privetstvuet-vypusk-pervykh-vrossii-regionalnykh-zelenykh-obligatsiy/ (accessed on 24 August 2021).

Zhang, J. et al. (2020), "Land Assets, Urban Investment Bonds, and Local Governments' Debt Risk, China", International Journal of Strategic Property Management, Vol. 25/1, pp. 65-75, http://dx.doi.org/10.3846/ijspm.2020.13834.

Zhivov, N. (2018), "The Thames Tideway Tunnel: A Hybrid Approach to Infrastructure Delivery", http://www.itf-oecd.org (accessed on 18 August 2021). 


\section{Find out more at}

\section{https://www.oecd.org/regional/}

\section{For more information, contact}

regions@oecd.org

Follow us on Social Media

@OECD_local

in linkedin.com/company/oecd-local/

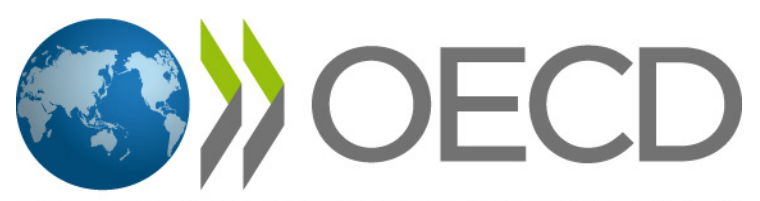

